RODRIGO GARDINAL

Utilização de uréia encapsulada de liberação lenta na alimentação de novilhos Nelore

Pirassununga

2011 
RODRIGO GARDINAL

Utilização de uréia encapsulada de liberação lenta na alimentação de novilhos Nelore

Dissertação apresentada ao Programa de Pós-Graduação em Nutrição e Produção Animal da Faculdade de Medicina Veterinária e Zootecnia da Universidade de São Paulo para obtenção do título de Mestre em Ciências

Departamento:

Nutrição e Produção Animal

Área de Concentração:

Nutrição e Produção Animal

Orientador:

Prof. Dr. Francisco Palma Rennó

Pirassununga 
Autorizo a reprodução parcial ou total desta obra, para fins acadêmicos, desde que citada a fonte.

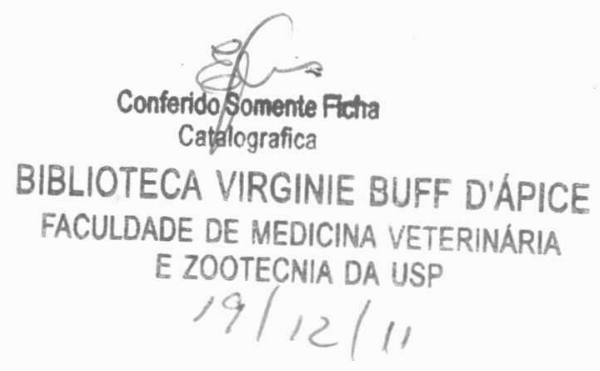

DADOS INTERNACIONAIS DE CATALOGAÇÃO-NA-PUBLICAÇÃO

(Biblioteca Virginie Buff D’Ápice da Faculdade de Medicina Veterinária e Zootecnia da Universidade de São Paulo)

\section{Gardinal, Rodrigo}

Utilização de uréia encapsulada de liberação lenta na alimentação de novilhos Nelore / Rodrigo Gardinal. -- 2012.

$110 \mathrm{f}$.

Dissertação (Mestrado) - Universidade de São Paulo. Faculdade de Medicina Veterinária e Zootecnia. Departamento de Nutrição e Produção Animal, Pirassununga, 2012.

Programa de Pós-Graduação: Nutrição e Produção Animal.

Área de concentração: Nutrição e Produção Animal.

Orientador: Prof. Dr. Francisco Palma Rennó.

1. Gado corte. 2. Ureia. 3. Ureia encapsulada de liberação lenta. 3. Sintese de proteína microbiana. 4. Balanço de nitrogênio. I. Título. 
GARDINAL, R. Utilização de uréia encapsulada de liberação lenta na alimentação de novilhos Nelore. 2011. 110 f. Dissertação (Mestrado em ciências) - Faculdade de Medicina Veterinária e Zootecnia, Universidade de São Paulo, Pirassununga, 2011.
Página
Parágrafo
Onde se lê
Leia-se
Resumo
1 은
2011. $110 \mathrm{f}$.
2012. $110 \mathrm{f}$.
Abstract
19
$110 \mathrm{f}$.
2012. $110 \mathrm{f}$. 
UNIVERSIDADE DE SÃO PAULO

\section{Comissão de Ética no uso de animais}

\section{CERTIFICADO}

Certificamos que o Projeto intitulado "Avaliação da utilização de uréia de liberação lenta na alimentação e saúde de ruminantes", protocolado sob o ${ }^{\circ}$ 1909/2010, utilizando 116 (cento e dezesseis) bovinos e 84 (oitenta e quatro) ovinos, sob a responsabilidade do Prof. Dr. Francisco Palma Rennó, está de acordo com os princípios éticos de experimentação animal da "Comissão de Ética no uso de animais" da Faculdade de Medicina Veterinária e Zootecnia da Universidade de São Paulo e foi aprovado em reunião de 26/05/ 2010.

We certify that the Research "Evaluation of controlled-release urea in fed and heath of ruminants", protocol number 1909/2010, utilizing 116 (one hundred sixteen) bovine and 84 (eighty-four) sheep, under the responsibility Prof. Dr. Francisco Palma Rennó, agree with Ethical Principles in Animal Research adopted by "Ethic Committee in the use of animals" of the School of Veterinary Medicine and Animal Science of University of São Paulo and was approved in the meeting of day 05/26/2010.

São Paulo, 27 de maio de 2010

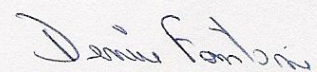

Profa. Dra. Denise Tabacchi Fantoni Presidente 


\section{FOLHA DE AVALIAÇÃO}

Nome: GARDINAL, Rodrigo

Título: Utilização de uréia encapsulada de liberação lenta na alimentação de novilhos Nelore

Dissertação apresentada ao

Programa de Pós-Graduação em

Nutrição e Produção Animal da

Faculdade de Medicina Veterinária

e Zootecnia da Universidade de

São Paulo para obtenção do título de Mestre em Ciências

Data:

\section{Banca Examinadora}

Prof. Dr.:

Instituição:

Prof. Dr.:

Instituição:

Prof. Dr.:

Instituição: 
Dedico este trabalho as pessoas que sempre me apoiaram tanto nas horas boas e, principalmente, nas ruins, que sempre me estenderam as mãos, me aconselharam, me incentivaram, me mostraram o caminho certo, fizeram cada dia da minha vida um grande motivo para se viver e querer viver mais e mais ao lado dessas pessoas, que a cima de tudo sempre quiseram a minha felicidade, e que tenho certeza que não mediram e nunca medirão esforços para que isto ocorresse, que mesmo estando longe, sempre estavam comigo, nem que fosse em pensamentos. Essas pessoas são meus familiares, em especial, a minha mãe Maria Tereza, meu pai Odair, meu irmão Claudemir, meu Tio Bila, minha tia Maria José, Tia Ligia Calomeni, Tio Cláudio Calomeni e meus primos Daniel, André, Cristiane..... e meus amigos, em especial Gustavo Calomeni, João Paulo D’andretta, Diego Cavalcanti, Bruno Barbosa..... 
"Que os vossos esforços desafiem as impossibilidades, lembrai-vos de que as grandes coisas do homem foram conquistadas do que parecia impossível."

\author{
Charles Chaplin
}




\section{AGRADECIMENTOS}

Gostaria de agradecer antes de tudo à Deus, que é a motivação intrínseca das minhas conquistas, o qual me guia e fortalece.

Agradeço à minha mãe, Maria Tereza, por todo apoio, carinho, esforço, e toda confiança depositada em mim, pois sei que não mediu, em momento algum, o esforço que tanto faz para me ajudar. Obrigado mamãe!

Agradeço ao meu pai, Odair, por todo apoio e compreensão, que mesmo dentro de nossas dificuldades, tenho certeza que sempre esteve ao meu lado. Obrigado Seu Oda!

Agradeço ao meu Tio Bila, pessoa que considero como um pai, que também nunca mediu esforço em nenhum momento para ver minha formação e minha felicidade. Obrigado Tio Bila, essa conquista tem grande parte de seu suor também.

Agradeço ao meu irmão Claudemir e minha cunhada Fabiana, que mesmo estando longe se preocuparam, apoiaram, incentivaram e ajudaram em todas as minhas decisões.

Agradeço a toda família Calomeni e Delfino, vó Celmi, Vô Jorge, tia Rosa, Tia Fátima, tio Chaim, Mariana, Dadaia, Vô Arnaldo, Vó Valdeci, tio Arnaldinho, tia Lí, Alexandre, Lucas, Guilherme e Andressa, pessoas essas que me acolheram e fizeram parte de minha vida nos últimos anos me colocando e me considerando como mais um membro da família. Em especial, quero agradecer ao Tio Cláudio e a Tia Ligia, ou melhor, Pai Cláudio e Mamãe Ligia, pelo carinho, pelo acolhimento, pela educação transmitida, pelo esforço que nunca deixaram de fazer para me ajudar a crescer, pelo apoio, incentivo, compreensão. Tio Cláudio e Tia Ligia vocês fizeram da minha vida em Pirassununga tudo mais fácil me dando tudo o que eu precisasse... Parte de 
tudo isso tem, com certeza, a mão de vocês..... Amo vocês... Muito, muito, muito obrigado de coração!!!!

Agradeço ao Gustavo Calomeni, amigo, parceiro e com certeza acima de tudo um irmão. Pessoa esta que sem duvida nenhuma, fez com que tudo ficasse mais fácil para esta minha conquista. Se fosse agradecer tudo o que fez e tem feito por mim, com certeza, precisaria dobrar o número de páginas dessa tese. Mas do fundo do meu coração obrigado por ser essa pessoa que você é, e a cima de tudo, obrigado por ser meu amigo. Valeu meu Brother....

Agradeço a minha amiga, ou melhor, namorada do Guzy, Camila Silano, pela amizade, pelo carinho, pela alegria transmitida, apoio e ajuda nessa minha caminha. Claro, pela paciência comigo também. Muito obrigado Cazy por fazer parte de tudo isso.

Agradeço a Silvana por toda ajuda, dedicação, paciência que teve comigo. Sil, se não fosse você o que seria dos nossos almoços e jantares? Obrigado

Agradeço ao meu orientador, professor doutor Francisco Palma Rennó, pela amizade, paciência, esforço e pela confiança depositada em mim nesses anos. Agradeço pelos conselhos e ensinamentos que muito me fizeram crescer, e ainda, pelo companheirismo nas horas de lazer, como churrascos, festas e futebol.

Agradeço aos meus amigos pirassununguenses, Kazu, Caio Heining, Guilherme Heining, Ticão, Jota, Leo, Donão, por toda ajuda, risada e momentos juntos, vocês fazem minha pirassununga cada vez mais divertida.

Agradeço ao Seu Zé Brasão, Dna Dedé, Tio Ana, Tia Coca, Tio Clésio, tio Fábio, Isabela, Ana Laura, Mariana, Julinha, Caio, Guilherme e Natan pelo carinho e acolhimento, vocês são uma família maravilhosa, espelho-me muito em vocês.

Agradeço ao Tio Zé Devitti, tia Patricia Devitti pelo carinho, amizade, pelas risadas juntas, pelas manhãs de academia, pelos finais de semana com muito samba. 
Agradeço ao Tio e Tia Duvalle, e ao tio Aurélio e tia Cláudia por toda alegria e receptibilidade.

A minha querida amiga, salve, salve, Nara Regina (Hilária), pessoa esta que tenho um carinho enorme, e que sem ela esse experimento não seria o mesmo. Obrigado pela paciência, alegria e conversas, sempre me alegrando, nesse quase um ano trabalhando juntos e escutando sua voz "agradável", durante as manhas experimentais. Hilária você é demais.

Ao trio, Mayara, Ana e Beatriz que me propuseram momentos de descontração e alegria nas manhãs de trabalho, ora humoradas, ora raivosas, ora correndo, mas como sempre falamos "No final tudo dá certo!!", obrigado por toda ajuda.

Agradeço ao Jeferson (Jefinho) por toda ajuda para conduzir meu experimento, principalmente nas manhãs de trabalhos. Obrigado pela força, explicações, risadas, paciência.

Agradeço a toda a equipe de pós do LPBL, Rafael Barleta (Bizão), Rodolfo (Badá), Vitor, Lenita, Cibelly, Gustavo (Xará), que sempre me ajudaram, que sempre estiveram e estão cedo no LPBL, com chuva ou com sol, sábado ou domingo. Obrigado

Agradeço ao José Ésler de Freitas Junior (Míííííííííirrrooooooo0000), por todo esforço, conhecimento, paciência, ajuda e conselhos. Agradeço ainda a alegria e aos momentos de descontração laboratoriais. Obrigado Cacatua esvoaçante!!

Aos funcionários e ex-funcionários do LPBL, Paulo, Tio Carlinhos Piologo, Tio Carlão, Diogo, Leno, Miguel e ao Jota. Sem a ajuda de vocês nada disso estaria pronto. Muito Obrigado.

Aos estagiários e alunos de iniciação científica, Karen, Bruno Lapo (Papi), Vivi, Caçapa, Poennimim, Jurema, Paola, Lea, Jolly, kumi, Sergay, Xoxa, a Pira, o Pira e em especial, ao Bumba e ao Catimbó. Vocês trouxeram alegria e muita vontade de aprender, sou muito grato a vocês. 
Agradeço aos meus amigos e companheiros Dangola, Dakus, Box, Mokréia, Farrapo, Biel, kustela, Clift, Pisti, Pikão, Pintainho, Virgem, Tropz, Grupo B da 70, em especial, ao Paquito, Ralé, Sake e Sybê que de uma forma ou de outra sempre procuraram estar presente nessa minha conquista, ajudando dentro do limite de cada um, mas que quando com eles sempre me propuseram momentos inesquecíveis, com muita risada e descontração.

Agradeço ao time de futsal da nossa querida faculdade, time este que me trouxe muita alegria e me mostrou o significado da palavra superação, confiança, superação e vontade. Não falo o nome de todos, pois esquecerei alguns, mas queria agradecer, em especial ao Marcelo (Tuto, Concha) e ao Teo, pessoas maravilhosas que moram no meu coração.

Aos companheiros, parceiros, amigos e colegas da Pós-graduação : Camila, Carol, Esther, Babi, Xibungo, Frodo, perna, Nara (corte), Juliano,Suzana, laçanã, Juliana Barreiro, Jú Diniz, Érika, Larissa, Dani (corte), Dani (leite), Henrique, Cris, Marina (corte), Marina (leite), Maria Fernanda, Fernanda, Francine, Nayara, Rafa, Rinaldo, Novilha, Bereba, Lara, Tássia, Pedro, Zé Alípio, Marília, Tarley, João Guilherme, Paula, Andréia, Fred, Laurinha, Claudinha e Débora, Xacrete, Rui (Libido), Alejandro, Natalino. Com certeza cada um de vocês fez parte de algum ou vários momentos especiais.

Em especial aos amigos: Caio Lucas, Gaúcho, Marinho (Maranhão) e Elmeson (Mineiro).

A todos os professores do Departamento de Nutrição e Produção Animal (VNP): Dr. Ricardo Albuquerque, Dr. Messias Alves da Trindade Neto, Dr. Paulo Henrique Mazza, Dr. Alexandre Gobesso, Dr. Anibal de Sant'Anna Moretti, Dra. Maria de Fátima Martins, Dr. Luis Felipe Prada e Silva, Marcos Veiga dos Santos e Dr. Romualdo Shigueo Fukushima pelos ensinamentos, colaboração e profissionalismo dispensados.

Aos professores do VRA, em especial ao Prof. Rubens, prof. Ed Hoffman e a profa. Annelise. 
Aos funcionários do VNP: Alessandra, João Paulo, Everson, Ari, Gilson, Lucinéia, Dona Lurdes, Fábia, Zequinha, Bigode, Cebolinha, e em especial, a Simi.

Aos funcionários Paulão e Dna Cecília do Hovet que ajudaram com muita paciência nas minhas análises, mesmo quando eu estava atrasado e atrasava eles. Obrigado

Aos funcionários da Fabrica de Ração da PCAPS, Srs. Cláudio de Jesus Aparecido São Romão, Israel Andrietta e José Luiz Aparecido Landgraf, agradeço a atenção dispensada.

Aos funcionários Estábulo leiteiro: Valmir, Coelho, Joãozinho, Tio Zé, Bala, Tadeu e Schimdt ( Estábulo leiteiro).

Agradeço a todos que de uma forma ou de outra me ajudaram, me ajuda, que fizeram ou fazem parte dessa minha jornada e que com certeza estou esquecendo. 


\section{RESUMO}

GARDINAL, R. Utilização de uréia encapsulada de liberação lenta na alimentação de novilhos Nelore. Use of polymer-coated slow release urea in the feeding of beef Nellore. 2011. 110 f. Dissertação (Mestrado em ciências) Faculdade de Medicina Veterinária e Zootecnia, Universidade de São Paulo, Pirassununga, 2011.

O presente estudo foi desenvolvido à partir de dois experimentos. No primeiro objetivou-se foi avaliar a utilização de uréia encapsulada de liberação lenta em dietas de novilhos Nelore canulados no rúmen e seus efeitos sobre o consumo e digestibilidade dos nutrientes, fermentação e produção microbiana ruminal, balanço de nitrogênio, e as concentrações de parâmetros sangüíneos. Foram utilizados 8 novilhos canulados da raça Nelore, mantidos em regime de confinamento, alocados em baias individuais cobertas, tipo tie stall. Os animais foram distribuídos aleatoriamente em 2 quadrados latinos $4 \times 4$ balanceados $e$ contemporâneos, para receber as seguintes rações experimentais: 1) Controle (C), composta por ração sem a inclusão de uréia; 2) Uréia pecuária (Reforce N) (U), com a utilização de 2,0\% de uréia pecuária na ração, baseada na matéria seca; 3) Uréia encapsulada 1 (UE-1), a utilização de 2,0\% de uréia encapsulada com o polímero 1 na ração, baseada na matéria seca; e 4) Uréia encapsulada 2 (UE-2), com a utilização de 2,0\% de uréia encapsulada com o polímero 2 na ração, baseada na matéria seca. $O$ volumoso foi a silagem de milho, sendo a proporção volumoso: concentrado da dieta de 50:50. Foi observado maior consumo de MS, MO, PB, EE, CNF, FDN, FDN e consumo de MS em relação a \%PV nos animais controle em relação aos alimentados com uréia. Foi observado menor digestibilidade da PB nos animais controle em relação aos alimentados com uréia. Maiores concentrações de $\mathrm{N}^{-N_{3}}$ ruminal foram observadas nos animais alimentados com uréia comum em relação aos alimentados com uréia encapsulada e maiores concentrações de propionato foram encontradas nos animais alimentados com uréia encapsulada em relação aos com uréia comum. Foi observado maior consumo de energia bruta, energia digestível, energia líquida, produção de energia líquida de ganho e 
eficiência energia líquida de produção nos animais submetidos a dieta controle em relação aos alimentados com uréia. Também foi observado maior consumo de nitrogênio $(\mathrm{N})$ (g/dia) nos animais controle em relação aos com uréia, ainda maior quantidade de $\mathrm{N}$ e \% $\mathrm{N}$ total nas fezes nos animais controle em relação aos alimentados com uréia e maior quantidade de $\mathrm{Ne} \% \mathrm{~N}$ urinário nos animais alimentados com uréia comum em relação aos com uréia encapsulada. Observou-se maiores concentrações de colesterol sérico nos animais controle em relação aos com uréia e maiores concentrações de uréia e $\mathrm{N}$-ureico séricos nos animais alimentados com uréia em relação aos com uréia encapsulada. A utilização de uréia encapsulada alterou positivamente a fermentação ruminal, porém níveis de inclusão de $2 \%$ diminui o consumo dos animais. No segundo experimento, objetivou-se avaliar a utilização de uréia encapsulada de liberação lenta em dietas de novilhos Nelore em confinamento e seus efeitos sobre o desempenho animal, qualidade de carcaça e parâmetros sanguíneos. Foram utilizados 84 animais novilhos inteiros, da raça Nelore, com idade aproximada de 18 meses e peso vivo inicial médio de $350 \mathrm{~kg}$. Os animais foram confinados por um período de 84 dias, precedido de um período de adaptação, de 7 dias para receber as seguintes rações experimentais: 1) Controle (C), composta por ração sem a inclusão de uréia; 2) Uréia pecuária (Reforce N) (U1), com a utilização de 1,0\% de uréia pecuária na ração, baseada na matéria seca; 3) Uréia pecuária (Reforce N) (U-2), com a utilização de 2,0\% de uréia pecuária na ração, baseada na matéria seca; 4) Uréia encapsulada 1 (UE1-1), a utilização de 1,0\% de uréia encapsulada com o polímero 1 na ração, baseada na matéria seca; 5) Uréia encapsulada 1 (UE1-2), a utilização de 2,0\% de uréia encapsulada com o polímero 1 na ração, baseada na matéria seca; e 6) Uréia encapsulada 2 (UE2-1), com a utilização de 1,0\% de uréia encapsulada com 0 polímero 2 na ração, baseada na matéria seca; e 7) Uréia encapsulada 2 (UE22), com a utilização de 2,0\% de uréia encapsulada com o polímero 2 na ração, baseada na matéria seca. $O$ volumoso utilizado foi a silagem de milho, sendo a proporção volumoso: concentrado da dieta de 50:50. As amostras de sangue foram coletadas no $28^{\circ}, 56^{\circ}$ e $84^{\circ}$ dias, junto com a pesagem dos animais. Após 84 dias de experimento os animais foram abatidos, foi avaliado, área de olho de lombo (AOL $\mathrm{cm}^{2}$ ) e espessura de gordura subcutânea (EGS mm) do 
músculo Longissimus. Foi observado maior ganho de peso (kg/dia) e peso final $(\mathrm{kg})$ nos animais alimentados com a dieta controle em relação aos alimentados com uréia e também maior ganho de peso nos animais alimentados com a dieta controle em relação aos alimentados com dietas contendo $2 \%$ de uréia. Também foi observado maior ganho de peso nos animais alimentados com dietas contendo $1 \%$ de uréia em relação aos alimentados com dietas contendo $2 \%$ de uréia. Observou-se menores concentrações de glicose sérica $(\mathrm{mg} / \mathrm{dl})$ e AST (UI/L) nos animais alimentados com uréia pecuária em relação aos alimentados com uréia encapsulada. Maiores concentrações $(\mathrm{mg} / \mathrm{dl})$ de uréia e nitrogênio ureico sérico foram observados nos animais alimentados com dietas contendo $2 \%$ de uréia em relação aos com $1 \%$ de uréia. A utilização de uréia encapsulada, independente dos níveis de inclusão na dieta, não influenciou na qualidade da carcaça dos animais. Quando utilizada com inclusão de $2 \%$ na dieta, influenciou negativamente o desempenho dos animais.

Palavras-chave: Gado de corte, Uréia, Uréia encapsulada de liberação lenta, Síntese de proteína microbiana, Balanço de nitrogênio. 


\begin{abstract}
GARDINAL, R. Use of polymer-coated slow release urea in the feeding of beef Nellore. Utilização de uréia encapsulada de liberação lenta na alimentação de novilhos Nelore. 110 f. Dissertação (Mestrado em ciências) Faculdade de Medicina Veterinária e Zootecnia, Universidade de São Paulo, Pirassununga, 2011.
\end{abstract}

The present study was developed from two experiments. At first the aim was to evaluate the use of polymer-coatedslow release urea in rations of Nelore bulls with ruminal cannulas and its effect on consumption and nutrient digestibility, rumen fermentation and microbial production, nitrogen balance, and blood parameters concentrations. Eight Nelore bulls with ruminal cannulas, kept in individual tie stalls, were assigned to two $4 \times 4$ contemporary Latin squares balanced to receive the following experimental diets: 1) Control (C), consisting of diet without the addition of urea, 2) Feed-grade Urea (FGU) with 2,0\% urea in ration, based on dry matter (DM), 3) Polymer-coated urea1 (PCU-1), with 2.0\% PCU1 in the ration, based on DM, and 4) Polymer-coated urea 2 (PCU-2) with $2.0 \%$ PCU2 in the ration based on DM. The forage source was corn silage, and the proportion forage:concentrate diet was 50:50. There was higher dry matter intake (DMI), original matter intake (OMI), crude protein (PB), ether extract (EE), non-fiber carbohydrates (NFC) and neutral detergent fiber (NDF) in relation to percentage of body weight (BW\%) in control animals compared with those fed urea. Lower digestibility of $\mathrm{CP}$ was observed in control animals compared with those fed urea. Higher concentrations of ruminal NH3-N were found in animals fed urea compared to those fed PCU and higher concentrations of propionate were found in animals fed PCU compared to those fed FGU. There was a higher consumption of gross energy, digestible energy, net energy, net energy production and efficiency gains net energy production in animals receiving control diet than those fed urea. There was a greater consumption of nitrogen $(\mathrm{N})$ ( $\mathrm{g} /$ day) in animals receiving control diet compared 
to urea fed groups, even greater amount of $\mathrm{N}$ and total \% $\mathrm{N}$ in feces in control animals than urea fed groups and higher $\mathrm{N}$ and \% urinary Nin ureafed animals compared to those fed PCU. Higher concentrations were observed in serum cholesterol in the control group compared urea fed groups and higher concentrations of urea and serum urea-N in FGU group compared to PCU group. The use of PCU positively affected ruminal fermentation, however inclusion levels of $2 \%$ decreases the intake of animals. In the second experiment, to evaluate the use of PCU in diets of bull calves in confinement and its effect on intake, animal performance, carcass quality and blood parameters. Animals were used 84 whole steers, Nellore, aged approximately 18 months and initial weight of $350 \mathrm{~kg}$. The animals were confined for a period of 84 days, preceded by an adaptation period of 7 days to receive the following experimental diets: 1) Control (C), consisting of diet without the addition of urea, 2) 1 FGU-1, with $1.0 \%$ urea in ration based on DM, 3) $2 F G U-1$, with $2.0 \%$ urea in ration, based on DM, 4) $1 \mathrm{PCU}-1$, with $1.0 \%$ PCU1 in ration, based on DM, 5) 2PCU-1 with 2.0\% PCU1 in ration, based on DM and 6) 1PCU-2, with $1.0 \%$ PCU2 in ration, based on DM, and 7) 2PCU-2, with2.0\% PCU2 in ration, based on DM. The forage source was corn silage, and the proportion forage: concentrate diet was 50:50. Blood samples were collected at the $28^{\text {th }}, 56^{\text {th }}$ and $84^{\text {th }}$ days with the weighing of the animals. After the $84^{\text {th }}$ of the experiment the animals were slaughtered, was evaluated rib eye area (REA square centimeters) and subcutaneous fat thickness (SFT mm) of the Longissimus muscle. There was more weight gain $(\mathrm{kg} /$ day) and final weight $(\mathrm{kg})$ in animals fed the control diet than those fed urea and these parameters were also higher in animals fed the control diet than those fed diets containing $2 \%$ urea and was even higher higher in animals fed diets containing $1 \%$ urea than those fed diets containing $2 \%$ urea. It was observed lower concentrations of serum glucose $(\mathrm{mg} / \mathrm{dl})$ and AST (IU L) in animals fed FGU than those fed PCU. Also, higher concentrations $(\mathrm{mg} / \mathrm{dl})$ of urea and serum urea nitrogen levels were observed in animals fed diets containing $2 \%$ urea compared to those with $1 \%$ urea in rations. The use of $\mathrm{PCU}$, regardless the levels in diet did not influenced the carcass quality When used with inclusion of $2 \%$ in the ration, had a negative effect on animal performance. 
Keywords: Dairy Cattle, Urea, Polymer-coated slow release urea, MicrobialProtein synthesis, Nitrogenbalance. 


\section{LISTA DE ABREVIAÇÕES E SIGLAS}

AG Ácidos Graxos

AST Aspartato Aminotranferase

BE Balanço de Energia

BN Balanço de Nitrogênio

CD Coeficiente de Digestibilidade

CED Consumo de Energia Digestível

CEL Consumo de Energia Líquida

CMS Consumo de Matéria Seca

CT Carboidratos Totais

DP Derivados de Purina

ED Energia Digestível

EE Extrato Etéreo

ELg Energia Líquida de Ganho

EM Energia Metabolizável

FDA Fibra em Detergente Ácido

FDAi Fibra em detergente ácido indigestível

FDN Fibra em Detergente Neutro

FS Farelo de Soja

GGT Gama Glutamiltranferase

MN Matéria Natural

MO Matéria Orgânica

MPCV Mudança de Peso de Corpo Vazio

MS Matéria Seca 


\begin{tabular}{ll} 
NDT & Nutrientes digestíveis totais \\
NIDA & Nitrogênio indigestível em detergente ácido \\
NIDN & Nitrogênio indigestível e detergente neutro \\
Nmic & Nitrogênio Microbiano \\
N-NH & Nitrogênio Amoniacal \\
Pabs & Purinas Absorvíveis \\
PB & Proteína Bruta \\
PBmic & Proteína bruta microbiana \\
PDR & Proteína Degradável no Rúmen \\
pH & Potencial Hidrogeniônico \\
Pmic & Proteína microbiana \\
PNDR & Proteína Não Degradável no Rúmen \\
PV & Peso Vivo \\
UE1 & Uréia encapsulada com polímero 1 \\
UE2 & Uréia encapsulada com polímero 2 \\
ULL & Uréia de liberação lenta \\
UP & Uréia protegida \\
\hline
\end{tabular}




\section{LISTA DE TABELAS}

Tabela 1. Composição da uréia encontrada no Brasil.......................................................... 35

Tabela 2. Composição bromatológica dos ingredientes da dieta.................................... 55

Tabela 3. Proporção dos ingredientes e composição bromatológica do concentrado experimental expressos na matéria seca (\%MS).

Tabela 4. Proporção dos ingredientes e composição bromatológica da ração experimental expressos na matéria seca (\%MS).

Tabela 5. Composição bromatológica dos ingredientes da dieta.

Tabela 6. Proporção dos ingredientes e composição bromatológica dos concentrados experimentais expressos na matéria seca (\%MS).

Tabela 7. Proporção dos ingredientes e composição bromatológica das dietas experimentais expressos na matéria seca (\%MS).

Tabela 8. Consumos e digestibilidade aparente total de matéria seca e nutrientes em função das dietas experimentais.

Tabela 9. Fermentação ruminal de acordo com as fontes de uréia utilizadas nas dietas experimentais.

Tabela 10. Síntese de proteína microbiana de acordo com as fontes de uréia utilizadas nas dietas experimentais.

Tabela 11. Balanço de energia de acordo com as dietas experimentais 81

Tabela 12. Balanço de nitrogênio em função das dietas experimentais.

Tabela 13. Parâmetros sanguíneos de acordo com as fontes de uréia utilizadas nas dietas experimentais.

Tabela 14. Desempenho e qualidade da carcaça de novilhos Nelore em confinamento em função das dietas experimentais.

Tabela 15. Parâmetros sanguíneos de novilhos Nelore em confinamento em função das dietas experimentais. 


\section{LISTA DE FIGURAS}

Figura 1. Ciclo da uréia no fígado (Santos, 2006).......................................................... 31

Figura 2. Metabolismo de nitrogênio (N) em ruminantes (Santos, 2006)

Figura 3. Fatores que afetam a síntese microbiana. Onde (1) representa a ação da enzima urease. Adaptado de Owens e Zinn, 1988)... 


\section{SUMÁRIO}

1. Introdução

2. Hipótese

3. Objetivos

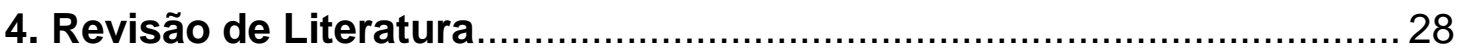

4.1. Nitrogênio não protéico na alimentação de ruminantes........................... 28

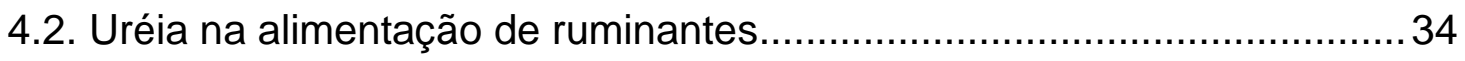

4.3. Uréia de liberação lenta na alimentação de ruminantes.......................... 37

4.4. Consumo de matéria seca...................................................................39

4.5. Digestibilidade aparente total dos nutrientes......................................42

4.6. Fermentação e síntese de proteína microbiana ruminal........................... 44

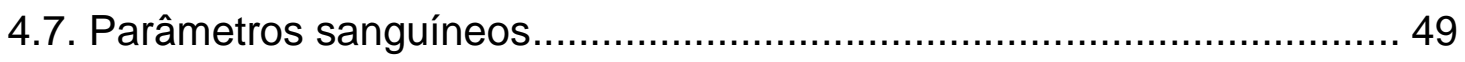

4.8. Desempenho e qualidade de carcaça..................................................... 50

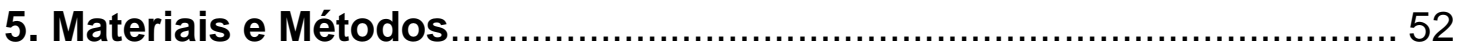

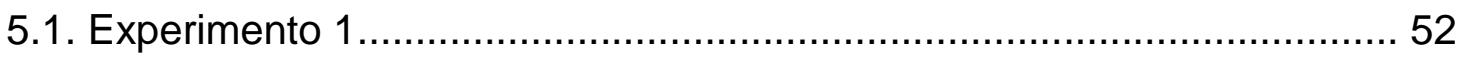

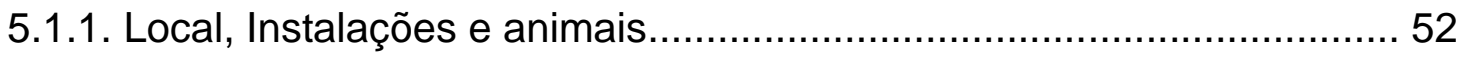

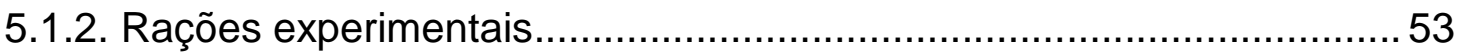

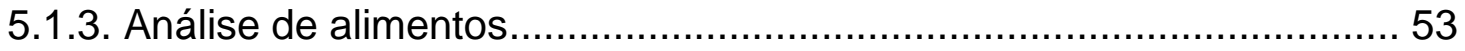

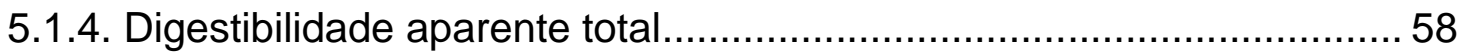

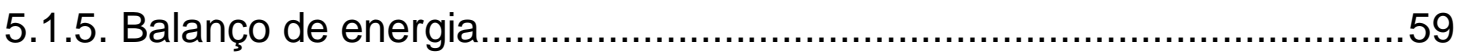

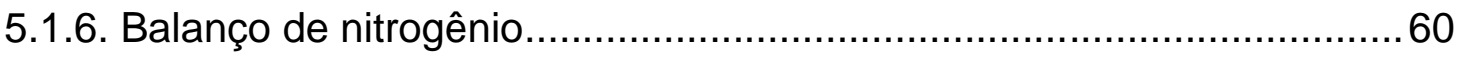

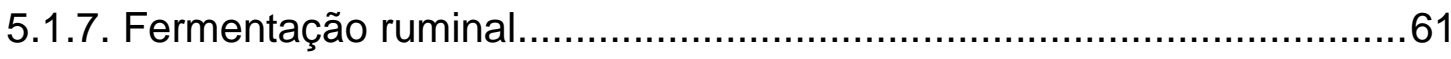

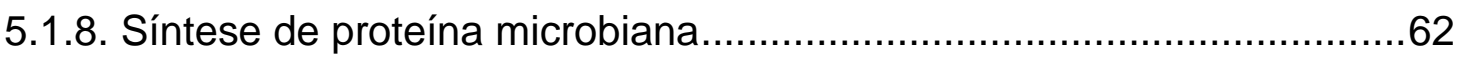

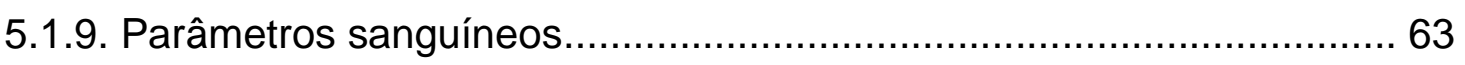

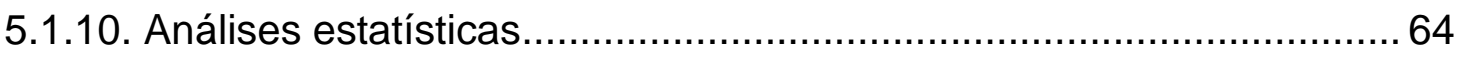


5.2. Experimento 2

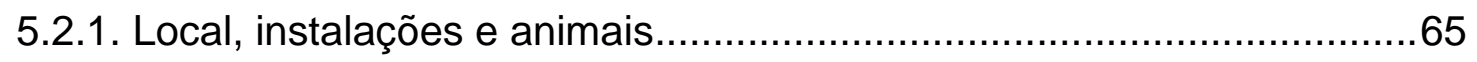

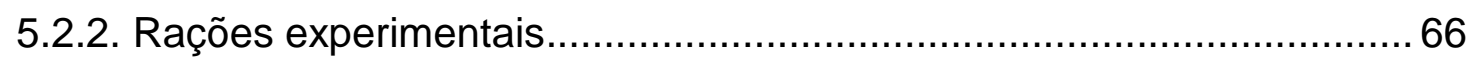

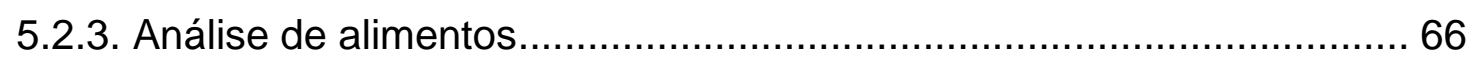

5.2.4. Desempenho e qualidade de carcaça................................................. 70

5.2.5. Parâmetros sanguíneos................................................................... 70

5.2.6. Análises estatísticas..................................................................... 71

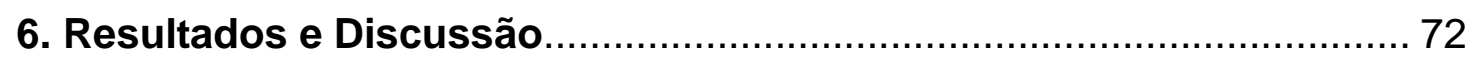

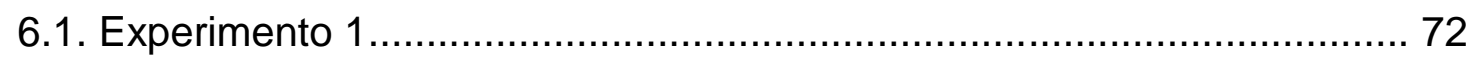

6.1.1. Consumo e digestibilidade aparente................................................. 72

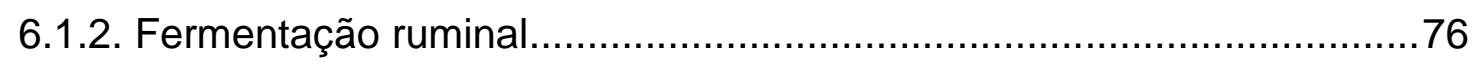

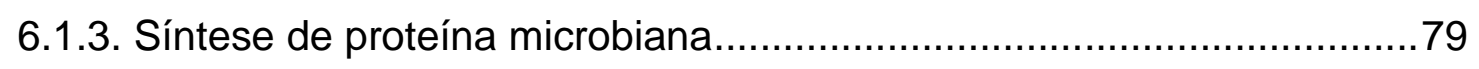

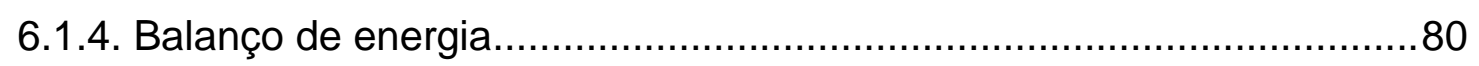

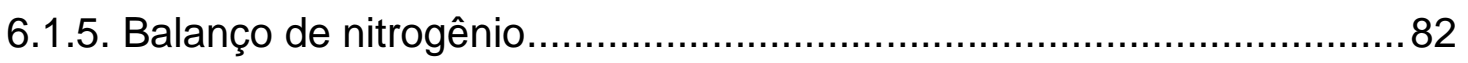

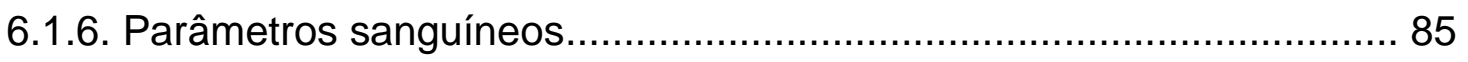

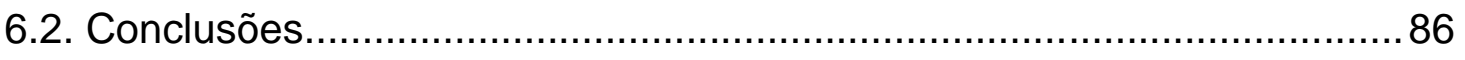

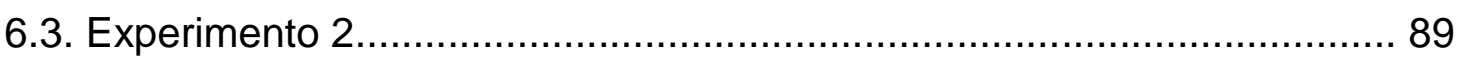

6.3.1. Desempenho e qualidade de carcaça................................................... 89

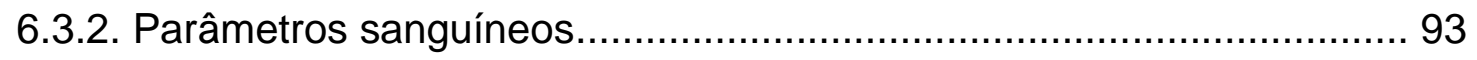

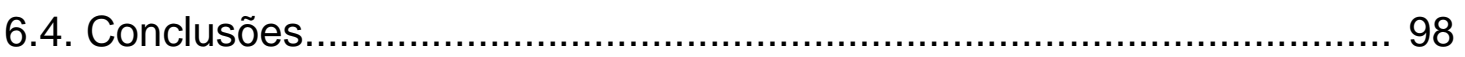

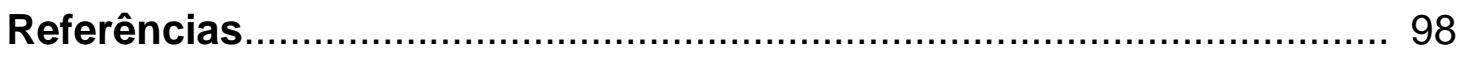




\section{Introdução}

Detentor do maior rebanho comercial bovino do mundo, com 176,6 milhões de cabeças (Anualpec, 2010) o agronegócio brasileiro possui a pecuária de corte como uma das mais importantes atividades, representando uma parcela substancial do PIB e gerando mais de nove milhões de empregos diretos e indiretos. A partir da década de 90, com as imposições da globalização, o setor pecuário (corte) tem apresentado avanços expressivos de desenvolvimento, aumentando sua competitividade produtiva e econômica.

Firmando-se como o maior exportador mundial de carne bovina e atualmente exportando para mais de 70 países, o Brasil vem conquistando cada vez mais mercados por todo mundo. Atualmente ocupa o terceiro lugar no consumo mundial de carne bovina e o segundo em produção de equivalente de carcaça, 7.778 milhares de toneladas (Anualpec, 2010). Com uma taxa de abate de $23 \%$ ao ano, representado 41,2 milhões de cabeças por ano, no ano de 2010, o Brasil exportou uma quantia de 1.230 .571 toneladas de carne o que representa quase cinco bilhões de dólares (ABIEC, 2010).

Com a tecnificação e a intensificação do processo produtivo na pecuária de corte, tem sido usada, entre outras, a prática do confinamento como alternativa na terminação de novilhos. Ao se considerar o elevado custo da terra, principalmente na Região Sudeste, o confinamento é uma estratégia capaz de satisfazer tanto o produtor quanto o consumidor, uma vez que permite reduzir o ciclo de produção e disponibilizar ao mercado carcaças de animais jovens e, conseqüentemente, de melhor qualidade, atendendo as exigências do mercado atual.

Nesse contexto, a alimentação dos animais confinados representa a maior porcentagem dos custos da produção e cabe aos pesquisadores encontrar formulações que viabilizem a utilização de produtos alternativos, em substituição aos alimentos tradicionais como o farelo de soja e o milho, sendo que estes devem ser de menor custo e não comprometer o desempenho dos animais ou que limitem a um certo ponto, de forma que o balanço final entre $o$ custo da alimentação e a receita gerada pelo ganho de peso dos animais seja positiva (Valadares et al., 2002). 
O processo evolutivo permitiu aos ruminantes o desenvolvimento do trato gastrintestinal que tornou possível a utilização de carboidratos fibrosos e de nitrogênio não protéico, convertendo estes em proteína de alta qualidade.

Sabe-se que, dos ingredientes de uma ração, os protéicos são os mais onerosos e sua utilização implica em maior custo por arroba na terminação de bovinos em confinamento. Nesse contexto, o farelo de soja é um dos principais ingredientes protéicos de origem vegetal, que se enquadra nesta realidade.

Atualmente, as principais metas da bovinocultura são aumentar a capacidade de conversão de nutrientes de origem vegetal em proteína animal para consumo humano, reduzir os custos na produção e diminuir o descarte de resíduos para o meio ambiente (Manella, 2004). Para atender essas premissas é necessário otimizar o uso de proteína pelo ruminante, manipulando-se as frações da proteína da dieta, de modo, que se tenha proteína degradável no rúmen (PDR) e proteína não degradável no rúmen (PNDR).

A uréia é uma importante fonte de PDR e tem sido o composto nitrogenado não protéico mais amplamente utilizado na dieta de bovinos, em virtude de seu baixo custo por unidade de nitrogênio, da disponibilidade no mercado, da facilidade de utilização e por não provocar decréscimo na produtividade ou aparecimento de problemas de saúde nos animais (Magalhães et al., 2002).

Compostos de nitrogênio não protéico (NNP), como a uréia, são convertidos em amônia no rúmen que pode ser utilizada ou absorvida através da parede ruminal (Van Soest, 1994). Entretanto, a quantidade de NNP utilizada é limitada devido à rápida hidrólise do nitrogênio das fontes de NNP em amônia no rúmen. Esta rápida taxa de quebra da amônia pode ocorrer muito mais rápida quando comparada à utilização de amônia pelas bactérias ruminais, resultando em acumulação e escape de amônia do rúmen (Satter e Roffler, 1975). Conseqüentemente, o excesso de amônia é absorvido pela parede ruminal e, uma vez na corrente sanguínea, a amônia pode ser tóxica para o animal (Blaxter, 1962).

Vários estudos vêm sendo realizados na tentativa de se avaliar os efeitos da manipulação da nutrição protéica devido à sua importância no metabolismo e desempenho de bovinos (Oliveira Jr., 2002). Nos últimos anos, 
a busca dos nutricionistas tem sido substituir fontes de proteína verdadeira por NNP. Considerando que a proteína bruta é o nutriente de maior custo na ração, à substituição de fonte protéica vegetal por uma com alta concentração de $\mathrm{N}$ como uréia, poderia resultar na redução dos custos do confinamento. Desta forma, o uso de uréia de liberação lenta pode ser uma alternativa positiva na substituição total ou parcial da proteína, como fonte de nitrogênio.

Alguns autores relataram que compostos com liberação controlada de nitrogênio, tais como amiréia, biureto, certos materiais de cobertura e a maioria dos complexos de uréia com formaldeído ou melaço, auxiliaram a evitar a toxicidade da amônia, mas não afetaram a utilização de nutrientes. A efetividade de liberação de nitrogênio nestes produtos varia muito pouco, podendo limitar a incorporação na proteína microbiana, ou liberação muito elevada de nitrogênio não proteíco, resultando em altos níveis de nitrogênio não proteíco sem ter outros substratos disponíveis no mesmo momento para utilização pelos microrganismos ruminais.

Os resultados, no entanto, são bastante variáveis. Os ensaios de liberação de amônia in situ são favoráveis ao uso do produto, pois comprovam uma liberação mais gradual (Ferreira, 2005), assim como trabalhos de avaliação metabólica (Huntington et al., 2006). No entanto, em experimentos de consumo, digestibilidade e desempenho não têm sido verificadas vantagens no uso de uréia de liberação lenta se comparado à uréia comum (Galo et al., 2003).

Desta forma, a utilização de uréia encapsulada na alimentação de ruminantes pode favorecer o melhor aproveitamento do nitrogênio disponível, sendo a liberação para o ambiente ruminal mais lenta e constante, favorecendo a fermentação e síntese de proteína microbiana ruminal, com reflexos positivos no desempenho produtivo do animal. 


\section{Hipótese}

Este projeto de pesquisa será constituído de dois experimentos:

1. A hipótese científica a ser avaliada no primeiro experimento é de que a utilização de uréia encapsulada de liberação lenta em dietas de novilhos canulados no rúmen altera positivamente o padrão de fermentação e síntese de proteína microbiana ruminal, sem influenciar, no entanto, o consumo e a digestibilidade das dietas.

2. A hipótese científica a ser avaliada no segundo experimento é de que a utilização de uréia encapsulada de liberação lenta em dietas de novilhos inteiros em confinamento melhora o desempenho dos animais, sem, no entanto, influenciar na qualidade da carcaça dos animais.

\section{Objetivos}

O primeiro experimento tem como objetivo avaliar a utilização de uréia encapsulada de liberação lenta em dietas de Novilhos nelore canulados no rúmen e seus efeitos sobre o consumo e digestibilidade aparente total da matéria seca e dos nutrientes, fermentação e produção microbiana ruminal, balanço de nitrogênio, e as concentrações de parâmetros sangüíneos.

O segundo experimento tem como objetivo avaliar a utilização de uréia encapsulada de liberação lenta em dietas de novilhos Nelore inteiros em confinamento e seus efeitos sobre o desempenho, qualidade de carcaça e parâmetros sanguíneos. 


\section{Revisão de Literatura}

\subsection{Nitrogênio não proteico na alimentação de ruminantes}

A proteína tem um papel fundamental na nutrição de ruminantes, sendo sua essencialidade não apenas pelo fornecimento de aminoácidos para 0 animal, mas também como fonte de nitrogênio para síntese de proteína microbiana (Oliveira Jr, 2002). A proteína da dieta é dividida em proteína degradável no rúmen (PDR) e proteína não degradável no rúmen (PNDR). A PDR é constituida de nitrogênio de proteína verdadeiro e não verdadeira. Proteína verdadeira é degradada a peptídeos e aminoácidos e, eventualmente, desaminada em nitrogênio amôniacal ou incorporado em proteína microbiana. A proteína não verdadeira é composta de nitrogênio não proteíco (NNP) que é aquele composto de nitrogênio presente no DNA, RNA, amônia, aminoácidos, e pequenos peptídeos. O nitrogênio de peptídeos, aminácidos e amônia são utilizados para o crescimento microbiano.

Diversos estudos foram conduzidos nos últimos 30 anos sobre o uso de fontes protéicas para ruminantes, tendo como objetivo maximizar a eficiência de utilização da proteína dietética, melhorar o desempenho animal e reduzir perdas de nitrogênio para o ambiente (Santos, 1998).

O objetivo da nutrição protéica dos ruminantes é disponibilizar ao animal uma adequada quantidade de proteína degradada no rúmen (PDR), para que ocorra eficiência dos processos digestivos neste compartimento gástrico e, conseqüentemente, otimizar o desempenho animal com a mínima quantidade de proteína bruta dietética (DePeters, 1992). A maximização da eficiência do uso da proteína bruta dietética requer a seleção de alimentos protéicos e suplementos de NNP, que possam disponibilizar quantidades adequadas de PDR que satisfaçam, mas não excedam, as exigências de nitrogênio necessárias para a máxima síntese de proteína microbiana, e, em determinadas situações, utilizar adequadas fontes de proteína não degradada no rúmen para o fornecimento de aminoácidos absorvíveis no intestino delgado 
em complementação a PDR. O suprimento de quantidades adequadas de PDR é fundamental para otimizar a produção de proteína microbiana (PM) e complementá-la adequadamente com PNDR e, assim, suprir as exigências em proteína metabolizável dos animais (Santos, 2006).

A proteína microbiana é normalmente a principal fonte de proteína metabolizável para ruminantes. A síntese de proteína microbiana no rúmen fornece a maioria de proteína fornecida para o intestino delgado de ruminantes, sendo responsável por 50-80\% de proteína total absorvível (Orskov e Macleod, 1983). A proteína não degradável no rúmen é a segunda fonte seguida da proteína endógena. A mistura de aminoácidos provenientes dessas fontes é denominada proteína metabolizável.

Microrganismos ruminais, principalmente as bactérias, utilizam carboidratos e proteínas como fontes de energia para realizarem a síntese microbiana. Os carboidratos são a principal fonte de energia para as bactérias, embora também sejam utilizados como esqueletos de carbono na síntese protéica microbiana em combinação com uma fonte de nitrogênio, principalmente amônia. Assim, a síntese de proteína microbiana ruminal depende do fornecimento de quantidades adequadas e do tipo de carboidratos como fonte de energia para a síntese de ligações peptídicas junto com fontes de nitrogênio, principalmente NNP. Carboidratos prontamente fermentáveis, como amido ou açúcares, são mais eficazes do que outras fontes de carboidratos, como a celulose (Hoover e Stern, 1982). Vários estudos in vitro (Stern et al, 1978; Henning et al, 1991) e in vivo (Casper e Schingoethe, 1989; Cameron et al, 1991) demonstraram que infusões de quantidades crescentes de carboidratos prontamente fermentáveis diminuiram as concentrações de amônia por causa da melhora da absorção de nitrogênio por microrganismos ruminais.

No entanto, a proporção ideal de carboidratos não fibrosos (CNF) com nitrogênio amoniacal ainda não foi bem determinada. Hoover e Stokes (1991) sugeriram que o crescimento microbiano máximo é atingido com uma relação 2:1 CNF:PDR. Embora essa relação não é viável em condições práticas, ilustra a importância do fornecimento de quantidades adequadas de nitrogênio disponível quando a energia não é o limitante. Além da importância do 
fornecimento das quantidades de nutrientes, a sincronia com que os nutrientes tornam-se disponíveis também é importante, pois uma dieta que é limitada em energia fermentável, com proteína bruta ou proteína altamente degradável em excesso, poderá ocorrer produção excessiva de amônia.

Contudo, nem toda amônia produzido poderá ser convertido em PM. A amônia em excesso é absorvida pela parede do rúmen e transportada para o fígado, onde ocorre a conversão em uréia, através do ciclo da uréia (Figura 1), a qual é lançada no sangue. A absorção de amônia é na sua maioria passiva, na forma não ionizada $\mathrm{NH}_{3}$ (Smith, 1975), isto é, essa passa através das membranas no sentido de uma concentração fisiológica menor (gradiente fisiológico). A quantidade de amônia na forma não ionizada no rúmen depende do $\mathrm{pH}$ e da quantidade total de amônia.

$\mathrm{O} \mathrm{pH}$ parece ser o fator mais importante na determinação da quantidade de amônia absorvida, sendo a proporção de amônia na forma não ionizada pequena $(0,38$ a $2,50 \%$ para $\mathrm{pH}$ de 6,62 a 7,42$)$. Para que se estabeleça rapidamente o equilíbrio da amônia que sai do meio, a forma não ionizada é rapidamente protonada para a forma ionizada: $\mathrm{NH}_{3}+\mathrm{H}^{+} \leftrightarrow \mathrm{NH}_{4}^{+}$(Visek, 1984, Huntington e Archibeque, 1999). Uma vez que a concentração de amônia na circulação periférica é mantida a baixos níveis devido à conversão de amônia a uréia no fígado, está retorna a circulação sanguínea e poderá seguir diferentes destinos: retornar ao rúmen via saliva, ou pela própria parede do rúmen, ou poderá ainda ser excretada na urina por meio de filtração renal. Quando a uréia retorna ao rúmen, é convertida novamente em amônia e pode-se utilizá-la como fonte de nitrogênio para bactérias (Bach, 2005; Valadares Filho, 2002). 


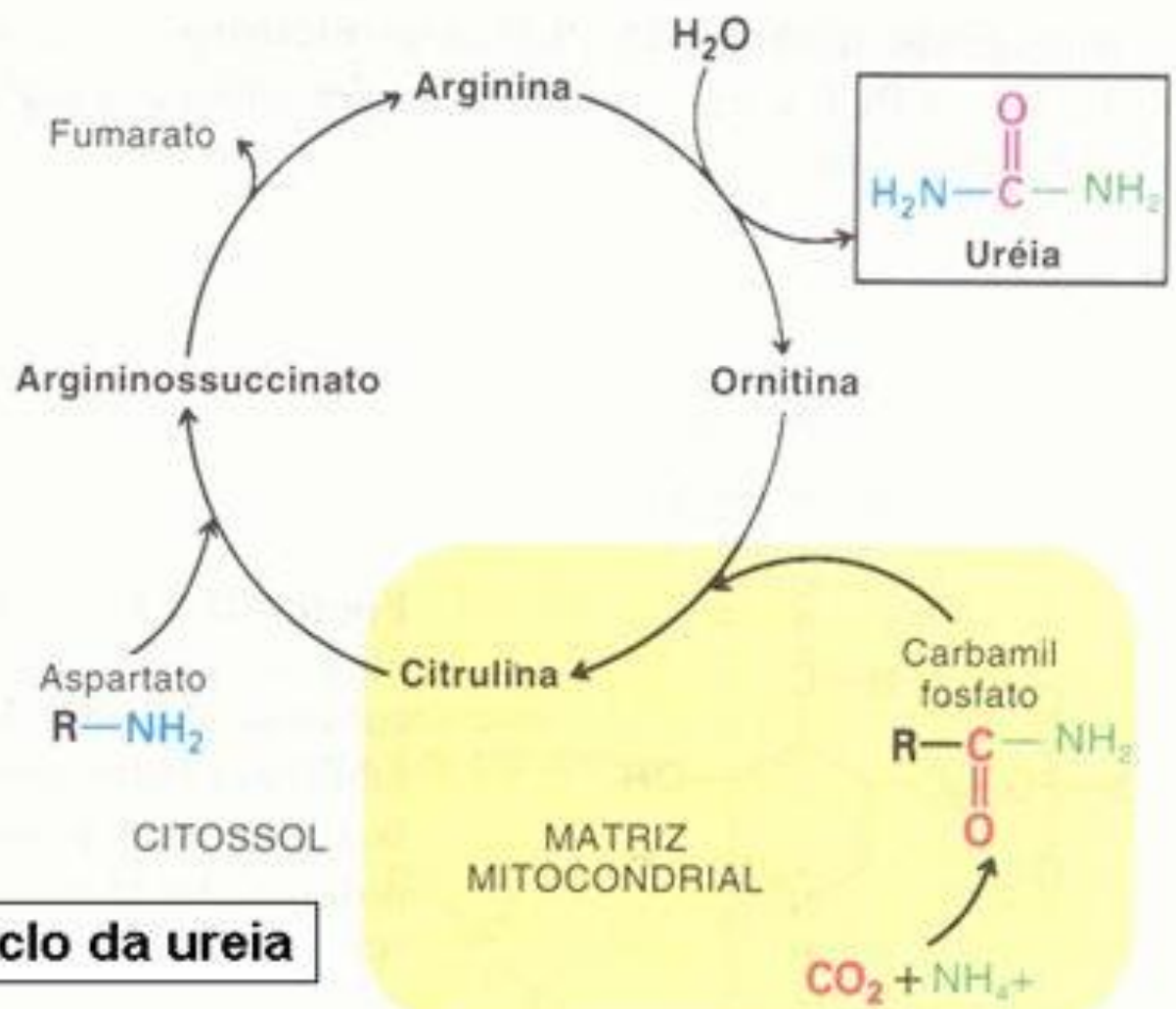

Figura 1. Ciclo da uréia no fígado (Santos, 2006)

Baseado no uso preferencial de energia pelas bactérias ruminais, estas são classificadas como celulolíticas e amilolíticas. Russell et al. (1992) propôs um modelo simplificado para descrever as exig6encias de energia e proteína de subpopulações microbianas. Microrganismos que degradam carboidratos estruturais (celulolíticos) têm pouca necessidade de manutenção, crescem lentamente, e utilizam amônia como fonte de nitrogênio, enquanto que os microorganismos que degradam carboidratos não estruturais (amilolítico) têm exigências mais altos de manutenção, crescem rapidamente, e utilizam amônia, peptídeos e aminoácidos como fontes de nitrogênio (Russell et al., 1992). As bactérias ruminais utilizam dois mecanismos distintos para a fixação de amônia nos esqueletos de carbonos durante a síntese de aminoácidos: a) através de enzima glutamina sintetase (GS); b) através da enzima glutamato desidrogenase $(\mathrm{GDH})$. Quando a concentração de amônia ruminal é alta, predomina a ação da GDH. Essa enzima não requer ATP para a fixação de amônia. Por outro lado, a atuação da enzima GS predomina quando a concentração de amônia ruminal é baixa. No caso da GS, para cada mole de 
amônia fixada há a utilização de 1 mole de ATP. Portanto, quando a concentração de amônia ruminal é baixa, a eficiência de síntese é reduzida, pois parte da energia que seria destinada para crescimento é utilizada no processo de fixação da amônia.

A quantidade total de proteína microbiana a fluir para o intestino delgado depende da disponibilidade de nutrientes e eficiência de utilização destes nutrientes pelas bactérias ruminais. Portanto, o metabolismo do nitrogênio no rúmen pode ser dividido em dois eventos distintos: a degradação protéica, que fornece fontes de nitrôgenio para as bactérias, e a síntese de proteína microbiana (Clark et al, 1992; Stern et al., 1994; Jouany, 1996; Firkins et al., 1998;. Dewhurst et al., 2000). O esquema abaixo ilustra todo o metabolismo de nitrogênio em ruminantes. (Figura 2) 


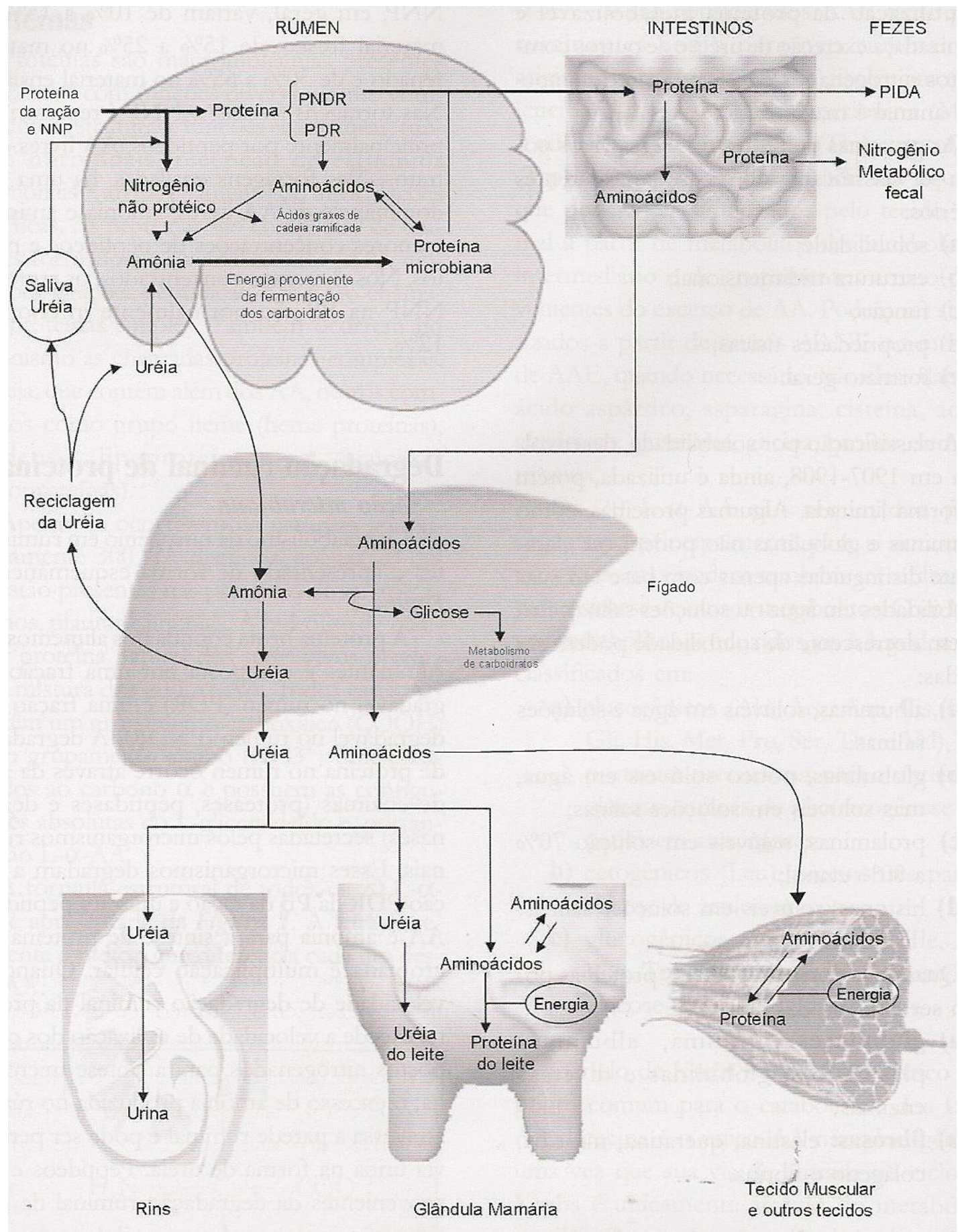

Figura 2. Metabolismo de nitrogênio (N) em ruminantes (Santos, 2006)

A suplementação com NNP, além de fornecer amônia para síntese de proteína microbiana (principalmente em bactérias, mas também de maneira mais reduzida em protozoários e fungos) e a menor custo ( $\mathrm{kg} \mathrm{de} \mathrm{N}$ ), apresenta outras vantagens: 1) cria uma ação tamponante no rúmen, de modo a manter o $\mathrm{pH}$ em uma faixa mais adequada para a digestão da celulose, 2) altera o hábito 
alimentar no sentido de refeições mais freqüentes, resultando em um possível incremento na eficiência energética da dieta (Huber, 1994), 3) diminui a excreção de resíduos nitrogenados para o meio ambiente.

Sob condições típicas na alimentação de gado de corte, manipulação ou degradação protéica ruminal, a eficiência de utilização do nitrogênio (EUN) no rúmen é a estratégia mais eficaz para reduzir as perdas de nitrogênio (Tamminga, 1996). Perdas de nitrogênio podem ser reduzidas, diminuindo a degradação da proteína no rúmen e (ou) aumentando o nitrogênio utilização pelos microorganismos ruminais.

Neste contexto, se insere a uréia como fonte de NNP. Uma fonte de NNP tem a vantagem de geralmente ser mais barata que uma fonte de proteína verdadeira na mesma quantidade de nitrogênio (Oliveira Jr., 2002). A quantidade de nitrogênio exigida pelos microrganismos é função da quantidade de energia disponível no rúmen, porque os protozoários e bactérias precisam de nitrogênio e energia, simultaneamente, para que ocorra uma proliferação desejável (Lucci, 1997).

\subsection{Uréia na alimentaçao de ruminantes}

As fontes de compostos nitrogenados utilizados na alimentação de bovinos podem ser classificadas como fontes de nitrogênio não protéico (NNP) e de nitrogênio protéico.

Atualmente, a principal fonte de NNP utilizado em rações de ruminantes é a uréia. Esta é adicionada na ração por dois motivos básicos. Do ponto de vista nutricional, ela é usada para adequar a ração em PDR. Do ponto de vista econômico, ela é utilizada com o objetivo de baixar o custo do suplemento proteíco (Santos, 2006).

A uréia é um composto orgânico sólido, solúvel em água e álcool, possui cor branca e é cristalizada por meio do sistema prismático. Quimicamente, é classificada como amida, daí ser considerada um composto nitrogenado não protéico, e possui em sua composição pequena quantidade de ferro e chumbo 
$(0,003 \%)$, não considerados tóxicos, além dos demais elementos: nitrogênio $(46,4 \%)$, biureto $(0,55 \%)$, água $(0,25 \%)$, amônio livre $(0,008 \%)$ e cinzas $(0,003 \%)($ Tabela 1) (Santos et al., 2001).

Tabela 1. Composição da uréia encontrada no Brasil.

\begin{tabular}{cc}
\hline Compostos & Proporção (\%) \\
\hline Nitrogênio & 46,4 \\
Biureto & 0,55 \\
Água & 0,25 \\
Amônia livre & 0,008 \\
Cinza & 0,003 \\
Ferro + Chumbo & 0,003 \\
\hline
\end{tabular}

Após a ingestão, a uréia é hidrolisada pela ação da urease sintetizada pelas bactérias do rúmen, produzindo amônia e dióxido de carbono.(Figura 3) A amônia é o composto central da síntese de proteína no rúmen, sendo incorporada na proteína microbiana, principalmente de bactérias, mas também, de modo mais reduzido, de protozoários e fungos. Desta forma, a uréia não pode ser considerada uma proteína verdadeira e sim um composto nitrogenado não protéico (Santos et al., 2001). 


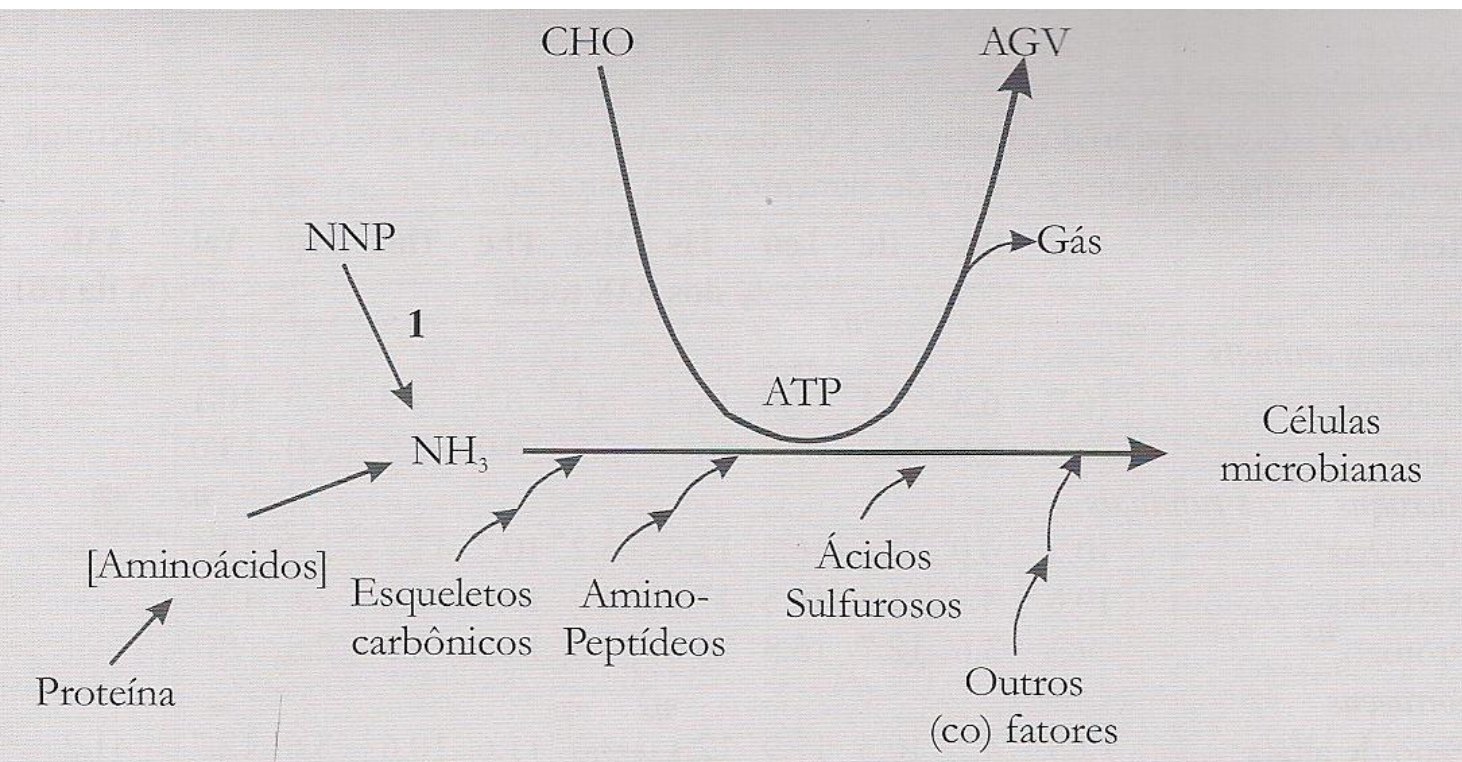

Figura 3. Fatores que afetam a síntese microbiana. Onde (1) representa a ação da enzima urease. Adaptado de Owens e Zinn, 1988).

A amônia é considerada um eletrólito fraco, de modo que, quando em solução, suas duas formas, ionizada $\left(\mathrm{NH}_{4}{ }^{+}\right)$e não ionizada $\left(\mathrm{NH}_{3}\right)$, estão em equilíbrio. As concentrações observadas de $\mathrm{NH}_{4}{ }^{+}$e $\mathrm{NH}_{3}$ na solução, dependem do $\mathrm{pH}$ e da temperatura (Visek, 1984). Baseado em princípios físico-químicos, deduziu-se que as membranas celulares de mamíferos são altamente permeáveis à forma não ionizada $\left(\mathrm{NH}_{3}\right)$ e que um rápido equilíbrio entre as formas $\mathrm{NH}_{3}$ e $\mathrm{NH}_{4}{ }^{+}$é estabelecido. A variação no $\mathrm{pH}$ por meio das membranas leva à formação de gradientes, concentrando a amônia dentro dos compartimentos com menor pH (Visek, 1984). De acordo com Ortolani e Antonelli (2004), em pH de 7,0, somente $1 \%$ da amônia permanece na forma não ionizada.

A adaptação dos animais à uréia utilizada nas dietas é prática de extrema importância, pois em situações de uso indiscriminado ou acidental, a uréia (seja em pó ou líquida) pode causar altas taxas de mortalidade (Ortolani e Antonelli, 2000). Comumente utiliza-se um máximo de 0,22g de uréia/kg de peso vivo, durante a primeira semana de adaptação, em rebanhos não adaptados. Rebanhos adaptados suportam níveis de uréia duas vezes maiores que o citado acima (Froslie, 1977). Assim, durante o metabolismo da uréia no 
rúmen, é preciso considerar suas diferentes transformações, como a hidrólise e o aproveitamento dos produtos finais do seu metabolismo, e seus efeitos sobre o estado metabólico do animal, pois condições adversas, como variações rápidas de $\mathrm{pH}$ e deficiência no fornecimento de energia, podem inviabilizar sua utilização, tornando-a perigosa do ponto de vista nutricional, em alguns casos. O período de adaptação representa um fator indispensável para o uso de uréia nas rações, permitindo ao animal adaptar o seu trato digestivo e flora microbiana à nova dieta e ter maior aproveitamento do nitrogênio fornecido.

Alguns autores como Salman et al. (1996) e Chalupa (1968) sugerem que 0 uso de uréia pelos ruminantes é limitado em virtude de sua baixa palatabilidade, sendo consistentemente eficiente quando não ultrapassa 1/3 do nitrogênio total ou $1 \%$ da matéria seca total da dieta. Porém, vários experimentos realizados com níveis de uréia acima dos recomendados mostraram que não houve prejuízo aos animais (Thomas et al., 1984; Hussein e Berger, 1995; Shain et al., 1998; Souza et al., 2002; Magalhães., et al 2003).

Para se calcular o percentual de proteína bruta ou total em determinado alimento, multiplica-se o percentual de nitrogênio existente pelo fator 6,25 (100 dividido por $16 \%$ de nitrogênio em média nas proteínas). Da mesma forma, para se calcular a quantidade de equivalente protéico da uréia ou outra fonte protéica (tiuréia, biureto, di-ureído-isobutano, ácido úrico etc) basta multiplicar o teor percentual de nitrogênio pelo fator 6,25 . Assim, para a uréia o equivalente protéico será de $290 \%$, ou seja, $46,4 \%$ N x 6,25 (Santos, 2001).

\subsection{Uréia de liberação lenta na alimentação de ruminantes}

A uréia de liberação lenta (ULL) surgiu como alternativa de modo a minimizar a alta conversão de uréia em amônia no rúmen, com o objetivo de disponibilizar a uréia de forma mais lenta, fazendo com que a conversão em amônia fosse modulada, assim, convergindo de modo mais estreito e paralelo com a digestão de carboidratos (Pinos-Rodríguez et al., 2010). Os compostos 
de uréia de liberação lenta que tem sido utilizado na alimentação de ruminantes incluem biureto, amiréia, fosfato de uréia, revestimentos à base de óleo, uréia tratada com formaldeído, e uréia revestida com polímeros (Taylor Edwards et al., 2009). Estes compostos não foram tão vantajosos como a utilização da uréia por si só porque parte substancial do NPN neles podiam deixar o rúmen sem ser convertidos em $\mathrm{NH}_{3}$, reduzindo sua incorporação na proteína microbiana (Galo et al, 2003; Firkins et al, 2007).

Recentemente, as propriedades de liberação lenta foram alcançadas usando uréia com substratos como cloreto de cálcio para controlar a taxa de liberação de $\mathrm{NH}_{3}$ (Huntington et al, 2006; Golombeski et al, 2006). Cherdthong et al. (2010), em experimento in vitro, verificou que mistura de sulfato de cálcio mais uréia reduziu as concentrações de $\mathrm{NH}_{3}$ ruminal, bem como melhorou a população microbiana, em comparação com uréia sem proteção. Ainda é relatado na literatura que a uréia de liberação lenta melhora a palatabilidade dos suplementos que contém uréia (Forero et al.,2001).

Segundo Akay et al. (2004), a uréia de liberação lenta com polímero confere tempo de degradação da uréia de até $16 \mathrm{~h}$, sendo a sua solubilização lenta e constante. Os autores avaliaram a utilização in situ do nitrogênio da uréia encapsulada comparando com a uréia comum e com a soja em grão. A degradação in situ da uréia de liberação lenta seguiu padrão mais semelhante ao da soja do que ao da uréia. A uréia de liberação lenta teve velocidade intermediária de utilização durante as primeiras $16 \mathrm{~h}$ de fermentação ruminal, seguida de velocidade mais lenta de utilização de 16 a 30h. Esse padrão de utilização em duas fases assemelhou-se ao observado para a soja. Em avaliações com fermentadores in vitro, o uso de uréia de liberação lenta permitiu maior síntese de proteína bacteriana e utilização mais rápida de nutrientes em relação à dieta com uréia tradicional, aumentando a utilização de FDA, FDN, e MO, em 16,6; 6,8; 4,0 e 8,0\%, respectivamente (Akat et al., 2004). 


\subsection{Consumo de matéria seca}

O consumo de matéria seca (CMS) é um importante critério para avaliação de dietas. O CMS depende de muitas variáveis, incluindo peso vivo, condições ambientais, fatores psicogênicos e de manejo, histórico de alimentação, condição corporal e tipo e qualidade dos ingredientes da ração, particularmente forragens (National Research Council - NRC, 1996).

Mertens (1992) afirmou que os pontos críticos para se estimar o consumo são as limitações relativas ao animal, ao alimento e às condições de alimentação. Quando a densidade energética da ração é alta (baixa concentração de fibra), em relação às exigências do animal, o consumo será limitado pela demanda energética. Para rações de densidade energética baixa (alto teor de fibra), o consumo será limitado pelo efeito de enchimento. Se houver disponibilidade limitada de alimentos, o enchimento e a demanda de energia não seriam importantes para predizer o consumo.

Segundo Van Soest (1994), o controle da ingestão de alimentos é o resultado de vários mecanismos inter-relacionados, que são integrados na resposta final de alimentação. O consumo de matéria seca é controlado por fatores fisiológicos de curto e longo prazo, em que o controle é realizado pelo balanço nutricional da dieta, especificamente relacionada à manutenção do equilíbrio energético, por fatores físicos, que estão associados à capacidade de distensão do próprio rúmen, e por fatores psicogênicos, que envolvem a resposta do animal a fatores inibidores ou estimuladores relacionados ao alimento e, ou, ao ambiente (Sniffen et al., 1993; Mertens, 1992; e Van Soest, 1994).

Estudando o efeito de níveis de uréia sobre o consumo e o ganho de peso, Obeid et al. (1980) utilizaram 72 novilhos Nelores inteiros, com 20 meses e $325 \mathrm{Kg}$ de PV, confinados durante 100 dias, utilizando silagem de milho como volumoso fornecida à vontade. Os tratamentos constituíram-se na substituição da proteína do farelo de soja pelo NNP da uréia (0, 50 e 100\%). A substituição de $100 \%$ da uréia comprometeu o ganho de peso dos animais $(1,03 ; 1,02$ e $0,80 \mathrm{Kg} / \mathrm{dia}$ ). O consumo de matéria seca e a conversão alimentar (CA) não foram afetados pelos tratamentos. 
Trabalhando durante 84 dias com 40 bovinos anelorados, de 18 meses e $271,0 \mathrm{Kg}$ de peso vivo, alimentados com rações contendo duas fontes de nitrogênio (farelo de algodão e milho $x$ milho e uréia) e utilizando como volumoso a cana-de-açúcar, na proporção de $60 \%$ na MS total, Coutinho Filho et al. (1995) observaram que o consumo de matéria seca não diferiu entre os tratamentos (2,6 e 2,4\% do PV), enquanto que a conversão alimentar foi superior para os animais cuja fonte dietética protéica foi o farelo de algodão (10,30 x 11,30 Kg de MS/Kg de ganho).

No estudo de Clarindo (2008) foi substituida uma fonte de proteína verdadeira (farelo de soja) por fonte de nitrogênio não-protéico (uréia), utilizando 24 animais Nelores machos, castrados, e dietas com 0, 0,75\% e 1,3\% de inclusão de uréia na ração em relação a matéria seca. Observou diferença no consumo entre os tratamentos onde a dieta sem uréia apresentou valor médio maior, mas os animais alimentados com farelo de soja apresentaram ganho de peso e eficiência alimentar superiores aos alimentados com uréia.

Paixão (2004) avaliou o efeito de duas fontes protéicas (farelo de soja e uréia) e dois níveis de oferta de concentrado ( 0,75 e 1,25\% do peso vivo) na dieta de 16 novilhos confinados, com peso médio inicial de $286 \mathrm{~kg}$, distribuídos num esquema fatorial $2 \times 2$, utilizando rações isoprotéicas (12\% PB) e volumoso constituído de silagem de capim-elefante e silagem de sorgo, numa relação de 80:20, respectivamente. Observou-se que a fonte protéica não afetou o consumo de matéria seca e dos nutrientes. Ainda, num segundo experimento realizado com quatro novilhos Holandeses com peso vivo médio inicial de $445 \mathrm{~kg}$, fistulados no rúmen e abomaso, tratados com dois níveis de uréia (0 e 100\%) em substituição ao farelo de soja e dois níveis de oferta de concentrado (0,75 e 1,25\% do PV), observou que o consumo de EE e CNF foram afetados pela fonte protéica.

Rennó et al. (2005) estudando o efeito de 4 níveis crescentes de uréia (0; 0,$65 ; 1,3$ e 1,95\% na MS) na ração, utilizando 16 animais confinados, castrados, de quatro grupos genéticos (Holandês, $1 / 2$ Holandês-Guzerá $(1 / 2 \mathrm{Hol}-$ Guz), $1 / 2$ Holandês-Gir (1/2Hol-Gir) e puros Zebu), mantidos em regime de confinamento e alimentados com feno de capim-tifton 85 (Cynodon spp) e 
concentrado, na relação 50:50, observaram que dentro dos grupos genéticos Holandês, $1 / 2$ Holandês- Guzerá e $1 / 2$ Holandês-Gir, a inclusão de níveis crescentes de uréia não influenciou o consumo de MS, com médias de 2,42; 2,35 e 2,20 \%PV, para os respectivos grupos genéticos. Somente para o grupo Zebu, o consumo de MS em \%PV, foi afetado de forma linear decrescente pela inclusão de uréia.

Ainda, Magalhães et al. (2002) alimentaram bovinos com grau de sangue variando de $1 / 2$ Holandês-Zebu até Holandês puro por cruza com 0; 0,65; 1,3 e 1,95\% de uréia na MS (no último tratamento, a uréia substituiu em 100\% o farelo de soja, com $65 \%$ de volumoso), relataram que o consumo de MS não foi afetado pela inclusão de uréia no concentrado, observando-se consumo médio de $2,55 \%$ PV.

Feijó et al. (1997), avaliaram o efeito da substituição do farelo de soja pela uréia $(0,50$ e 100\%) e do tipo de silagem (milho, sorgo granífero e sorgo de duplo propósito) sobre o desempenho e características de carcaça em 72 bovinos F1 Pardo Suíço x Nelore (experimento 1), inteiros, mantidos em regime de confinamento por um período de 92 dias, com dietas isoprotéicas, e silagem oferecidas à vontade e concentrado na proporção de $0,72 \%$ de PV. Foi observado que o consumo de matéria seca tendeu a ser menor à medida que 0 farelo de soja era substituído pela uréia $(2,19 ; 2,16$ e 2,15\% do PV). Ainda, observou-se diferença quanto a conversão alimentar (5,53; 6,09 e 7,52 Kg de $\mathrm{MS} / \mathrm{Kg}$ de ganho), ganho de peso $(1,71 ; 1,57$ e $1,24 \mathrm{~kg}$ de $\mathrm{PV} / \mathrm{dia})$ e 0 rendimento de carcaça $(54,3 ; 53,4$ e $52,9 \%)$ que foram menores à medida que o farelo de soja foi substituído pela uréia.

Em outro experimento, Feijó et al. (1997) utilizaram 48 novilhos Nelore com idade média de 34 meses e peso vivo médio inicial de $378 \mathrm{Kg}$, em esquema fatorial $2 \times 3$, sendo 2 silagens (sorgo granífero e sorgo de duplo propósito) e os mesmos três níveis de substituição do farelo de soja por uréia, confinados por 70 dias. Observou-se que a medida que a uréia substituiu gradativamente o farelo de soja, ocorreu redução do consumo de MS $(10,08$; 9,94 e 9,49 kg de MS/dia). Porém, o ganho médio diário de peso e a CA não foram influenciados pelos níveis de uréia e apresentaram médias, respectivamente, de $1,02 \mathrm{~kg}$ e 7,40 kg de MS/kg de ganho. 
Magalhães (2003), avaliando o efeito de 4 níveis de uréia na dieta (0; 0,$65 ; 1,30$ e $1,95 \%$ de uréia na base da MS total) substituindo a proteína do farelo de soja na dieta de 24 novilhos de origem leiteira, em confinamento, junto a mistura de volumoso contendo silagem de milho e silagem de capimelefante, na proporção 70:30, respectivamente, com uma relação volumoso:concentrado da dieta total de 65:35, observou-se que o consumo não foi afetado pelos níveis de uréia das dietas, com exceção do consumo de PDR, que apresentou comportamento linear crescente.

Galina et al. (2003) alimentaram novilhos zebuínos com 100\% de canade-açúcar (T1), cana-de-açúcar suplementada com 1,8 kg de MS de uréia de liberação lenta (T2) e cana-de-açúcar: milho (40:60\%) suplementada com 1,8 $\mathrm{kg}$ de MS de uréia de liberação lenta (T3). Ao avaliarem o consumo voluntário de matéria seca e consumo de matéria orgânica verificaram que ambos foram maiores para as dietas contendo uréia de liberação lenta.

\subsection{Digestibilidade aparente total dos nutrientes}

A digestão dos ruminantes envolve constante atividade simbiótica dos microrganismos ruminais com o hospedeiro, que são altamente susceptíveis às alterações do meio, afetando não só a extensão da degradação dos componentes dos alimentos, mas também as quantidades e proporções dos produtos resultantes da ação destes.

A associação entre composição química e o potencial de degradação dos alimentos vai determinar o maior ou menor crescimento microbiano e produção de ácidos graxos voláteis no rúmen, que são as principais fontes de proteína e energia para bovinos, respectivamente (Crurch, 1990).

Os fatores mais importantes que afetam a degradação de proteína microbiana incluem o tipo de proteína, interações com outros nutrientes (principalmente carboidratos dentro do mesmo alimento e no conteúdo 
ruminal), e a população microbiana predominante (dependente do tipo de ração, taxa de passagem ruminal, e $\mathrm{pH}$ ruminal).

Os pesquisadores têm buscado cada vez mais o controle de liberação de nitrogênio oriundo da uréia, a fim de permitir maior sincronização com a degradabilidade dos carboidratos, sendo estes mais aproveitados pelas bactérias ruminais, aumentando a eficiência e o fluxo de proteína microbiana, reduzindo as necessidades de fontes protéicas verdadeiras e conseqüentemente melhorando o desempenho animal.

Silveira et al. (2009) utilizando oito novilhos mestiços Europeu $\times$ Zebu, canulados no rúmen e no duodeno, com peso vivo médio inicial de $410 \mathrm{~kg} \mathrm{e}$ aproximadamente 26 meses de idade, avaliaram três fontes protéica na dieta com cana-de-açúcar (uréia, farelo de soja ou farelo de glúten de milho - 60), sobre a degradabilidade in situ da matéria seca e de fibra em detergente neutro. Observaram que não houve diferença entre os tratamentos na degradabilidade da matéria seca, entretanto, o maior valor de degradabilidade efetiva da FDN foi obtido com a dieta contendo farelo de soja.

Rennó et al. (2005) estudando o efeito de 4 níveis crescentes de uréia (0; 0,65; 1,3 e 1,95\% na MS) na ração sobre a digestibilidade, observaram que a digestibilidade aparente total da matéria seca não foi influenciada pelos grupos genéticos e nem pelos níveis de uréia nas rações.

Paixão (2004) avaliando o efeito de duas fontes protéicas (farelo de soja e uréia) e dois níveis de oferta de concentrado ( 0,75 e 1,25\% do peso vivo) na ração sobre a digestibilidade observou que a fonte protéica não afetou nenhuma das digestibilidades estudados. Ainda, num segundo experimento realizado com quatro novilhos Holandeses com peso vivo médio inicial de 445 $\mathrm{kg}$, fistulados no rúmen e abomaso, tratados com dietas contendo dois níveis de uréia (0 e 100\%) em substituição ao farelo de soja e dois níveis de oferta de concentrado ( 0,75 e 1,25\% do PV), com volumoso constituído de silagem de capim-elefante e silagem de sorgo numa relação de 80:20, respectivamente, observou que a digestibilidade aparente total dos CNF foi maior no tratamento com uréia $(86,54 \times 83,90)$.

Magallhães (2003) avaliando o efeito de 4 níveis de uréia na dieta (0; 0,$65 ; 1,30$ e 1,95\% de uréia na base da MS total) em substituição a proteína 
do farelo de soja sobre a digestibilidade, observou que as digestibilidades da matéria seca e proteína bruta aumentaram linearmente com os níveis de uréia nas rações.

\subsection{Fermentação e síntese de proteína microbiana ruminal}

A eficiência de síntese de proteína microbiana no rúmen depende dos efeitos da fermentação ruminal sobre a degradação e sincronização dos componentes dos alimentos e sobre a síntese de compostos a serem utilizados pelo hospedeiro através da absorção ruminal e intestinal (Hoover, 1986). Isto determina a melhor ou pior capacidade de conversão do alimento em produto animal (carne e leite).

O objetivo final da nutrição ruminal adequada é maximizar o crescimento microbiano e a quantidade de PDR que é capturado pelas células microbianas no rúmen. Maximizar a captura de nitrogênio degradável não só melhora o fornecimento de aminoácidos para o intestino delgado, mas também diminui perdas de nitrogênio. $O$ conhecimento dos compostos de nitrogênio necessários para o crescimento de bactérias ruminais é importante para a compreensão da nutrição protéica de ruminantes e os fatores que afetam a fermentação ruminal, particularmente a digestão de fibras.

O rúmen é um ambiente complexo habitado por diferentes espécies microbianas, cada uma delas com diferentes necessidades de nutrientes e metabolismos. Portanto, considerar as necessidades de nutrientes dos microorganismos ruminais é fundamental para a compreensão do metabolismo do nitrogênio no rúmen, bem como os fatores que podem modificá-lo.

O conhecimento dos compostos nitrogenados necessários para 0 crescimento de bactérias ruminais é importante para a compreensão da nutrição protéica de ruminantes e os fatores que afetam a fermentação ruminal, particularmente a digestão de fibras. Há uma antiga crença de que bactérias celulolíticas ruminais usa nitrogênio amoniacal como sua única fonte 
de nitrogênio. Alguns resultados recentemente publicados não são consistentes com esta conclusão (Russell et al., 2009)

Russell et al. (1983) em estudo relatou que os microrganismos que fermentam carboidratos não fibrosos derivam cerca de $66 \%$ das proteínas de peptídeos ou aminoácidos, e o restante obtém a partir de nitrogênio amoniacal. Esses pesquisadores afirmam que esta proporção não é influenciada pela taxa de crescimento microbiano e que na ausência de carboidratos, todo nitrogênio de peptídeos seriam convertidos em amônia. No entanto, a concentração ótima de peptídeos no rúmen necessária para maximizar a síntese de proteína microbiana não foi determinada. Atasoglu et al. (1999) relataram que a proporção de nitrogênio bacteriano derivado de amônia diminui à medida que a relação de nitrogênio amoniacal:nitrogênio total disponível diminui.

Recentemente, Atasoglu et al. (2004) estudaram o destino do nitrogênio e carbonos de aminoácidos em misturas de microrganismos ruminais. Os resultados mostraram que várias aminoácidos foram sintetizadas por microrganismos do rúmen com maior dificuldade do que outros. Em geral, acredita-se que os microrganismos ruminais não tem um requisito absoluto para qualquer aminoácido, assim, Atasoglu et al. (2004) sugere que alguns aminoácidos pode estar limitando o crescimento. Eles também confirmaram a teoria de que bactérias do rúmen têm dificuldade em sintetizar Phe, Leu, e lle (Oltjen et al, 1971; Amin e Onodera, 1997) e propõem que Lys é um aminoácido potencial limitante para 0 crescimento de bactérias no rúmen. Portanto, assegurar 0 abastecimento generoso de aminoácidos especificamente pode resultar em maior crescimento microbiano.

Além de um fornecimento adequado de carboidratos e fontes de nitrogênio, bem como outros fatores nutricionais, como o fornecimento de enxofre, outros fatores não-nutricionais, como o pH ruminal e taxa de diluição, também desempenham um papel importante na síntese de proteína microbiana. Em condições práticas, a eficiência de síntese de proteína microbiana (ESPM) permanece relativamente constante dentro de uma ampla faixa de $\mathrm{pH}$. Para avaliar o potencial efeito do $\mathrm{pH}$ ruminal e ESPM, uma metaanálise descrito por St-Pierre (2001), foi realizada com a literatura fornecendo dados in vivo $(\mathrm{n}=187)$, utilizando análise de regressão de modelo misto. Os 
resultados desta meta-análise com as observações ajustadas para o efeito médio de estudo mostra nenhuma relação entre $\mathrm{pH}$ ruminal e ESPM. Estas observações concordam com estudos in vitro (Hoover e Miller, 1992; Calsamiglia et. al, 2002). Em contraste, o fluxo total do nitrogênio bacteriana é negativamente relacionada com $\mathrm{pH}$. $\mathrm{pH}$ ruminal baixo é resultado da fermentação de grandes quantidades de matéria orgânica disponíveis. Quando a quantidade de matéria orgânica fermentada aumenta, a síntese de proteína microbiana também aumenta (Hoover e Stokes, 1991). Como resultado, a relação negativa entre $\mathrm{pH}$ e fluxo de nitrogênio bacteriano é conseqüência do aumento da oferta de energia com rações altamente fermentáveis ( $\mathrm{pH}$ baixo).

Silveira et al. (2009), utilizando oito novilhos mestiços Europeu $\times$ Zebu, canulados no rúmen e no duodeno, avaliaram três fontes protéica na dieta com cana-de-açúcar (uréia, farelo de soja ou farelo de glúten de milho - 60), sobre a eficiência de síntese microbiana e observaram que as diferentes fontes protéicas não diferiram em relação a síntese de proteína microbiana e $\mathrm{pH}$ ruminal. Sales et al. (2008), estudando a inclusão de diferentes níveis de uréia na alimentação a pasto $(0,0 ; 1,6 ; 3,2$ ou $4,8 \%$ na matéria natural) em 4 animais mestiços Holandês $\times$ Zebu, não-castrados, com peso médio inicial de $320 \mathrm{~kg}$, fistulados no esôfago, rúmen e abomaso sobre os parâmetros nutricionais de bovinos, observaram que os níveis de uréia não afetaram significativamente 0 $\mathrm{pH}$ e a concentração de amônia ruminal $\left(\mathrm{N}-\mathrm{NH}_{3}\right)$.

Rennó et al. observaram que o $\mathrm{pH}$ ruminal apresentou comportamento semelhante para os grupos genéticos e foi influenciado positivamente pela inclusão de uréia na dieta, já as concentrações de $\mathrm{N}-\mathrm{NH}_{3}$ foram influenciadas positivamente pelos níveis de uréia na ração apenas para os animais holandeses e mestiços.

Paixão (2004) bservaram que a síntese de proteína microbiana não foi afetada pelos tratamentos, apresentando média de 112,55 g de PB por $\mathrm{Kg}$ de NDT. Ainda, num segundo experimento realizado com quatro novilhos Holandeses com peso vivo médio inicial de $445 \mathrm{~kg}$, fistulados no rúmen e abomaso. Observou-se que tanto $\circ \mathrm{pH}$ quanto $\circ \mathrm{N}-\mathrm{NH}_{3}$ foram afetados pela fonte protéica, onde foram observados maiores valores médios na dieta com uréia tanto, para $\mathrm{pH}(6,35 \times 6,10)$ como para $\mathrm{N}-\mathrm{NH}_{3}(39,15 \times 21,40)$. 
Oliveira Jr et al. (2004) utilizando seis novilhos da raça Nelore, distribuídos em delineamento em quadrado latino $3 \times 3$ duplicado, avaliaram a substituição total de uma fonte de proteína verdadeira (farelo de soja), por uréia ou amiréia (fontes de nitrogênio não protéico) e bagaço de cana-de-açúcar in natura como única fonte de volumoso (20\% da MS) sobre a concentração de amônia ruminal. Foi observado maior concentração de $\mathrm{N}-\mathrm{NH}_{3}$ no tratamento que continha apenas uréia, e os tratamentos com amiréia e farelo de soja não diferiram entre si. Magallhães (2005) avaliou o efeito de 4 níveis de uréia na dieta $(0 ; 0,65 ; 1,30$ e 1,95\% de uréia na base da MS total) sobre a produção de proteína microbiana e observou que não houve efeito dos níveis de uréia nas rações sobre a eficiência de síntese microbiana.

Galina et al. (2003) observaram proporção molar de acetato menor para ambas as dietas com uréia de liberação lenta. Além disto, a concentração de amônia e a digestão das frações potencialmente digestíveis e indigestíveis foram aumentadas nas dietas com uréia de liberação lenta.

Xin et al. (2010) em estudo avaliaram os efeitos da uréia revestida com poliuretano sobre a concentração de ácido graxos voláteis (AGV) ruminal em vacas leiteiras de raça holandesa alimentadas com dieta a base de silagem de milho. Utilizaram três tratamentos i) dieta com uréia tradicional (DUT) ; ii) dieta com uréia revestida com poliuretano (DUP) e iii) dieta com isolado de proteína de soja (DIPS). No estudo não foram observadas diferenças na concentração de AGV totais entre os três tratamentos, mas as porcentagens molares dos AGV individuais foram significativamente alterados pelos tratamentos dietéticos. Às dietas a base de uréia resultaram em maior proporção de acetato e menores de propionato que a dieta DIPS, o que causou um aumento na relação acetato:propionato.

Um estudo recente conduzido por Taylor-Edwards. et al (2009) que mensurou os efeitos da uréia de liberação lenta (ULL) versus uréia tradicional sobre N-NH3 ruminal em bovinos de corte, onde novilhos multi-cateterizados foram utilizados para determinar os efeitos de doses intra-ruminais de ULL ou uréia tradicional sobre o fluxo de nutrientes e as variáveis de sangue por $10 \mathrm{~h}$ após a administração, no sistema porta das viceras (SPV). Observou-se que a dosagem intra-ruminal da ULL impediu o rápido aumento das concentrações de 
$\mathrm{N}-\mathrm{NH}_{3}$ ruminal, o que diferentemente ocorreu com a dosagem de uréia tradicional. A uréia tradicional sofreu hidrólise rápida no rúmen para $\mathrm{N}$ $\mathrm{NH}_{3}$. Isso significou que concentrações $\mathrm{N}^{-N_{3}}$ ruminal dosadas foram 263\% maiores nos animais tratados com uréia tradicional do que nos novilhos tratados com ULL, principalmente porque as concentrações $\mathrm{N}-\mathrm{NH}_{3}$ ruminal do tratamento com uréia tradicional subiu de forma acentuada em $0,5 \mathrm{~h}$ após a administração. Os autores relatam que este rápido aumento na concentração de $\mathrm{N}^{-\mathrm{NH}_{3}}$ para o tratamento com uréia tradicional foi significativo o suficiente para aumentar o pH ruminal por mais de 0,5 unidade dentro de $0,5 \mathrm{~h}$ após a administração.

Ainda, o $\mathrm{pH}$ ruminal e as concentrações de $\mathrm{N}^{-\mathrm{NH}_{3}}$ ruminal foram positivamente relacionados. Além disso, observou-se que as concentrações de $\mathrm{N}-\mathrm{NH}_{3}$ ruminal permaneceram maiores para novilhos tratados com uréia tradicional do que aqueles tratados com ULL até 8 a 10h após a administração. Estes resultados demonstram que in vivo a ULL, de fato, têm taxa mais lenta de liberação de $\mathrm{N}-\mathrm{NH}_{3}$ do que a uréia tradicional e pode efetivamente modular concentrações $\mathrm{N}^{-\mathrm{NH}_{3}}$ ruminal quando substituído por uréia (Highstreet et al., 2010; Inostroza et al., 2010; Pinos-Rodríguez et al., 2010; Xin et al., 2010).

A utilização do nitrogênio por microrganismos do rúmen pode ser refletida pela concentração de $\mathrm{N}-\mathrm{NH}_{3}$ ruminal. Num estudo in vitro realizado por Xin et al. (2010), utilizando uréia revestida com poliuretano e uréia tradicional, as concentrações de $\mathrm{N}-\mathrm{NH}_{3}$ de todas as dietas aumentaram dentro de $1 \mathrm{~h}, \mathrm{e}$ depois diminuíram gradualmente. No entanto, a dieta com uréia revestida de poliuretano (URP) apresentou uma menor concentração de $\mathrm{N}^{-\mathrm{NH}_{3}} \mathrm{em}$ todos os momentos. Ainda, durante um intervalo de $8 \mathrm{~h}$ de fermentação in vitro, a dieta com URP diminuiu a concentração de $\mathrm{N}^{-\mathrm{NH}_{3}}$ de $8,2-20,6 \%$ em comparação com a dieta de uréia tradicional. Isto concorda com o resultado de Prokop e Klopfenstein (1977), que descobriram que a uréia de liberação lenta (combinação de uréia e formol) poderia diminuir a concentração de $\mathrm{N}-\mathrm{NH}_{3}$ ruminal em $25,3 \%$ quando comparada com uréia tradicional. Ainda, nenhuma diferença significativa foi encontrada entre URP e a dieta com farelo de soja na liberação de $\mathrm{N}-\mathrm{NH}_{3}$ ruminal. Este resultado é semelhante ao encontrado no 
relatório de Galo (2003), em que a liberação de uréia a partir de uma uréia revestida com polímero foi $83 \%$ tão extensa como a uréia sem revestimento, após $1 \mathrm{~h}$ de incubação com água destilada. Outros produtos, tais como uma combinação uréia e cálcio, tiveram efeitos semelhantes. Cass e Richardson (1994) fizeram uma comparação em um estudo in vitro e observaram que uma combinação de uréia e cálcio produzia uma taxa de liberação mais lenta de $\mathrm{N}-\mathrm{NH}_{3}$ do que a uréia tradicional. No estudo, as concentrações de $\mathrm{N}^{-\mathrm{NH}_{3}}$ começaram a aumentar em $8 \mathrm{~h}$ para a dieta com uréia tradicional. No entanto, as concentrações de $\mathrm{N}-\mathrm{NH}_{3}$ com dietas contendo URP e farelo de soja diminuíram. Com base nesses resultados, pode-se inferir que dietas com uréia de liberação lenta prolongam a utilização de fontes adicionais de nitrogênio durante a fermentação ruminal. Portanto, a sincronização entre a liberação de $\mathrm{N}-\mathrm{NH}_{3}$ ruminal e disponibilidade de carboidratos pode ser melhorada, conseqüentemente resultando em maior síntese de proteína microbiana.

\subsection{Parâmetros sanguíneos}

A concentração de nitrogênio ureico e uréia plasmática tem sido usada como indicador do status protéico, particularmente em comparações qualitativas entre fontes e/ou níveis de ingestão de compostos nitrogenados dietéticos (Preston et al., 1965). A uréia plasmática é eliminada pelos rins, por filtração glomerular e reabsorção tubular por processo passivo, secundário à reabsorção de fluidos (Malnic e Marcondes, 1986). Assim, a quantidade de uréia excretada é influenciada por estas funções, além de ser, de acordo com Harmeyer e Martens (1980), alterada principalmente por sua concentração plasmática, sob várias condições dietéticas. A excreção fracional de uréia é, segundo estes autores, constante em ruminantes e próxima de $50 \%$. No entanto, Aires (1985) afirmou que esse parâmetro pode variar de 30 a 60\%.

Rennó et al. (2008) estudando o efeito de 4 níveis crescentes de uréia (0; 0,$65 ; 1,3$ e 1,95\% na MS) na ração sobre a concentração plasmática de 
uréia, observaram que $\mathrm{N}$-uréico plasmático aumentou linearmente em função dos níveis de uréia. Paixão (2004) avaliando o efeito de duas fontes protéicas (farelo de soja e uréia) e dois níveis de oferta de concentrado (0,75 e 1,25\% do peso vivo) na ração sobre a concentração de uréia plasmática, observou que as concentrações de $\mathrm{N}$-uréico no plasma não foi influenciado pela fonte protéica. Magallhães (2005), também não observou efeito dos níveis de uréia sobre a concentração de uréia plasmática. Oliveira Jr et al. (2004) observaram resultados semelhantes de que a concentração de nitrogênio uréico no plasma e a concentração de glicose plasmática foram similares entre tratamentos.

\subsection{Desempenho e qualidade de carcaça}

O grau com que dietas suplementadas com uréia são capazes de suportar ganhos de peso em novilhos confinados tem sido inconsistente, necessitando estudos mais acurados para definir a quantidade de uréia que poderia ser utilizada (Thomas et al., 1984). No que concerne a níveis de substituição, a recomendação tradicionalmente adotada pela maioria dos pesquisadores é que o NNP pode substituir até $33 \%$ do nitrogênio protéico da dieta dos ruminantes (Velloso, 1984). Ainda tem sido sugerido limitar a quantidade de uréia em até 1,0\% na matéria seca total da dieta (Haddad, 1984).

De acordo com Mertens (1994), 60 a 90\% do desempenho animal é função direta do consumo de alimentos. Seixas et al. (1999), ao avaliarem o desempenho de novilhos em confinamento, recebendo dietas a base de silagem de milho e três fontes protéicas: amiréia 30 , uréia $(1,30 \%$ na $M S)$ e farelo de algodão, não reportaram diferenças para as médias de ganho de peso. Da mesma forma, Shain et al. (1998), trabalhando com níveis crescentes de uréia $(0 ; 0,88 ; 1,34$ e 1,96\% na MS) na dieta de novilhos, não evidenciaram diferenças quanto ao ganho de peso, porém salientaram que os animais suplementados com uréia na ração, tiveram ganhos mais elevados e foram eficientes do que aqueles que não receberam uréia. 
Entretanto, Feijó et al. (1997) e Knaus et al. (2001) encontraram desempenhos inferiores, evidenciados em especial, pelo menor ganho de peso, em animais alimentados com uréia quando comparado àqueles que receberam fontes de proteína verdadeira, e atribuíram esse comportamento à insuficiência de PNDR nas dietas que continham uréia em sua composição.

A carcaça é um elemento muito importante do animal, pois contém a porção comestível (carne). Sendo assim, as informações das características de carcaça passaram a ser parâmetros fundamentais, e com isso, a rentabilidade na produção da porção comestível, bem como os cortes de importância comercial. Existem alguns fatores, associados à qualidade da carne, que são de um consenso geral e estão diretamente ligados ao aumento da maciez, da suculência e do sabor. Portanto, na tecnologia de carnes, o termo qualidade tem sentido amplo, associando características quantitativas e qualitativas da carcaça e da carne.

Dentre as características de carcaça mais importantes encontram-se 0 rendimento $(R C)$ e peso de carcaça quente (PCQ), por serem características diretamente relacionadas à produção de carne e pode variar de acordo com fatores intrínsecos e/ou extrínsecos ao animal (URANO et al. 2006), esses fatores são: idade, sexo, raça, cruzamento, peso ao nascer e peso ao abate, além da nutrição animal.

Além do rendimento, o peso de carcaça, dentre outras medidas são importantes para avaliação da carcaça, dentre elas: a área de olho de lombo (AOL) e espessura de gordura subcutânea (EGS). A área de olho lombo medida entre a $12^{\mathrm{a}}$ e a $13^{\mathrm{a}}$ costelas é amplamente aceita e utilizada como um indicador da composição de carcaça, e, apesar de apresentar uma pequena associação com a quantidade de carne magra, ela pode ser utilizada como um indicador dessa composição (LUCHIARI FILHO, 2000). O grau de acabamento das carcaças é avaliado pela EGS, sendo esta a característica de maior impacto no rendimento, visto que o rendimento de carne magra diminui com o aumento na EGS.

Magalhães (2003), em estudo com novilhos, não verificou diferença entre os tratamentos com diferentes níveis de uréia $(0 ; 0,65 ; 1,30 ; 1,95)$ na EGS, assim como Hussein e Berger (1995), em experimento, não verificaram 
comprometimento das características de carcaça dos animais, quando $50 \%$ da proteína do farelo de soja foi substituída pela uréia. Shain et al. (1998), trabalhando com animais em confinamento recebendo níveis crescentes de uréia na ração $(0 ; 0,88 ; 1,34$ e 1,96\% na MS), não encontraram diferenças no peso de carcaça quente e na EGS nos animais dos diferentes tratamentos. Resultados semelhantes foram encontrados por Milton et al. (1997) usando níveis crescentes de uréia $(0 ; 0,5 ; 1,0$ e 1,5\% na MS) na ração de novilhos em terminação, verificando que a AOL não foi afetada pelos diferentes níveis, enquanto que a EGS apresentou comportamento linear crescente com a inclusão de uréia na dieta.

\section{Materiais e Métodos}

\subsection{Experimento 1}

\subsubsection{Local, Instalações e animais}

O experimento foi realizado no Laboratório de Pesquisa em Bovinos de Leite (LPBL) do Departamento de Nutrição e Produção Animal (VNP) da Faculdade de Medicina Veterinária e Zootecnia da Universidade de São Paulo (FMVZ-USP), situado no Campus Administrativo da USP de Pirassununga, no período de 05 Julho a 18 de Agosto de 2010.

A localização geográfica do campus da USP em Pirassununga é 21059 de latitude sul e $47^{\circ} 26^{\prime}$ de longitude oeste (W.Gr) e altitude média de 635 metros. O clima da região é tropical do tipo Cwa na classificação de Koppen, e a temperatura média anual é de $20,8^{\circ} \mathrm{C}$, com precipitação pluviométrica média anual de $1298 \mathrm{~mm}$.

Foram utilizados 8 novilhos castrados da raça Nelore (Bos taurus indicus) com média de peso vivo e idade de $503 \mathrm{~kg}$ e 22 meses de idade respectivamente. Os animais foram canulados no rúmen segundo a metodologia descrita por Leão e Coelho da Silva (1980). As unidades 
experimentais foram agrupados em dois quadrados latinos $4 \times 4$ balanceados $e$ contemporâneos, com duração do período experimental de 11 dias, sendo 7 dias de adaptação e 4 dias de coleta de amostras.

Os animais foram mantidos em regime de confinamento, alocados em baias individuais cobertas, tipo tie stall, com piso de concreto, dotadas de comedouros de alvenaria e bebedouros automáticos.

\subsubsection{Rações experimentais}

As dietas fornecidas aos animais em estudo foram compostas por quatro rações durante todo o período experimental, formuladas para serem isonitrogenadas, isocalóricas e isoenxofre, de forma a atenderem as exigências nutricionais de novilhos em crescimento com ganho de peso corporal de aproximadamente $0,80 \mathrm{~kg} / \mathrm{dia}$, conforme recomendações do NRC (1996).

Os animais foram distribuídos aleatoriamente para receber as seguintes rações experimentais: 1) Controle (C), composta por ração sem a inclusão de uréia; 2) Uréia pecuária (Reforce N) (U), com a utilização de 2,0\% de uréia pecuária na ração, baseada na matéria seca; 3) Uréia encapsulada 1 (UE-1), a utilização de 2,0\% de uréia encapsulada com o polímero 1 na ração, baseada na matéria seca; e 4) Uréia encapsulada 2 (UE-2), com a utilização de 2,0\% de uréia encapsulada com o polímero 2 na ração, baseada na matéria seca.

A forragem oferecida foi constituída de silagem de milho, sendo a proporção volumoso: concentrado da dieta de 50:50, respectivamente.

\subsubsection{Análise de alimentos}

Diariamente foram feitas as pesagens das quantidades dos volumosos e concentrados fornecidos e das sobras de cada tratamento. Os animais foram arraçoados 1 (uma) vezes ao dia, às 7:00, de acordo com o consumo de 
matéria seca do dia anterior, de forma a ser mantido um porcentual diário de excedente da dieta, entre 5 e $10 \%$ para que não houvesse limitação de consumo.

As duas porções constituintes da ração, concentrado e volumoso, foram misturadas no cocho e fornecidas na forma de dieta completa. Ao final de cada período de adaptação era realizada a coleta e armazenamento a $-20^{\circ} \mathrm{C}$ do $\mathrm{pool}$ de amostras de alimentos e sobras obtidos durante as coletas para posterior análise de nutrientes.

As análises químico-bromatológicas foram realizadas no Laboratório de Bromatologia do VNP-FMVZ-USP. A proporção dos ingredientes no concentrado e dieta total, assim como a respectiva composição bromatológica das rações experimentais, concentrados e ingredientes encontram-se nas Tabelas 2, 3 e 4.

Nos alimentos fornecidos e nas amostras de sobras foram analisados os teores de matéria seca $(M S)$, matéria orgânica $(M O)$, matéria mineral $(M M)$, extrato etéreo $(\mathrm{EE})$, proteína bruta $(\mathrm{PB})$, nitrogênio insolúvel em detergente neutro (NIDN), nitrogênio insolúvel em detergente ácido (NIDA) e lignina, de acordo com as metodologias descritas por Silva e Queiroz (2002). 
Tabela 2. Composição bromatológica dos ingredientes da dieta.

\begin{tabular}{|c|c|c|c|c|}
\hline Composição química & $\begin{array}{l}\text { Silagem de } \\
\text { Milho }\end{array}$ & $\begin{array}{c}\text { Farelo } \\
\text { de Soja }\end{array}$ & $\begin{array}{l}\text { Milho } \\
\text { Moído }\end{array}$ & $\begin{array}{c}\text { Grão de } \\
\text { Soja }\end{array}$ \\
\hline Matéria Seca (MS) ${ }^{1}$ & 34,76 & 90,21 & 89,89 & 95,32 \\
\hline Matéria Orgânica $(\mathrm{MO})^{2}$ & 94,32 & 94,05 & 98,38 & 94,46 \\
\hline Matéria Mineral $(\mathrm{MM})^{2}$ & 5,67 & 5,95 & 1,62 & 5,54 \\
\hline Proteína Bruta $(\mathrm{PB})^{2}$ & 9,68 & 50,67 & 8,90 & 39,04 \\
\hline $\mathrm{NIDN}^{2}$ & 18,43 & 4,88 & 10,20 & 17,27 \\
\hline $\mathrm{NIDA}^{2}$ & 10,09 & 2,75 & 4,20 & 6,60 \\
\hline Extrato Etéreo $(E E)^{2}$ & 2,70 & 2,48 & 2,51 & 20,73 \\
\hline Carboidratos Totais $(\mathrm{CT})^{2}$ & 83,11 & 40,90 & 86,97 & 34,69 \\
\hline Fibra em Detergente Neutro $(F D N)^{2}$ & 52,46 & 12,61 & 11,64 & 17,01 \\
\hline Carboidrato não Fibroso $(\mathrm{CNF})^{2}$ & 30,65 & 28,29 & 75,33 & 17,68 \\
\hline Fibra em Detergente Ácido (FDA)² & 36,90 & 9,90 & 4,10 & 14,64 \\
\hline $\mathrm{FDAi}^{2}$ & 14,08 & 0,82 & 1,13 & 0,94 \\
\hline Lignina $^{2}$ & 4,59 & 0,89 & 0,99 & 2,26 \\
\hline $\mathrm{NDT}^{2}$ & 63,33 & 81,48 & 87,52 & 98,73 \\
\hline ELL $(\text { Mcal } / k g)^{3}$ & 1,30 & 2,30 & 2,10 & 2,80 \\
\hline $\mathrm{EB}(\mathrm{cal} / \mathrm{g} / \mathrm{MS})^{3}$ & 3878,63 & 4129,50 & 3891,25 & 5016,75 \\
\hline
\end{tabular}


Tabela 3. Proporção dos ingredientes e composição bromatológica do concentrado experimental expressos na matéria seca (\%MS).

\begin{tabular}{|c|c|c|c|c|}
\hline \multirow{2}{*}{ Ingredientes (\%) } & \multicolumn{4}{|c|}{ Dietas experimentais } \\
\hline & $\mathrm{C}^{4}$ & $U^{5}$ & UE-1 $1^{6}$ & UE-2 $2^{7}$ \\
\hline Fubá de milho & 62,74 & 88,32 & 88,32 & 88,32 \\
\hline Farelo de soja & 21,42 & - & - & - \\
\hline Grão de soja & 11,81 & 3,41 & 3,41 & 3,41 \\
\hline Uréia & - & 4,00 & 4,00 & 4,00 \\
\hline Mistura Mineral & 3,99 & 4,00 & 4,00 & 4,00 \\
\hline Calcário & 0,21 & 0,21 & 0,21 & 0,21 \\
\hline Sal & 0,21 & 0,21 & 0,21 & 0,21 \\
\hline \multicolumn{5}{|l|}{ Composição química (\%MS) } \\
\hline Matéria Seca (MS) & 91,39 & 91,06 & 91,06 & 91,06 \\
\hline Matéria Orgânica $(\mathrm{MO})^{2}$ & 93,02 & 90,11 & 90,11 & 90,11 \\
\hline Matéria Mineral $(\mathrm{MM})^{2}$ & 10,04 & 10,04 & 10,04 & 10,04 \\
\hline Proteína Bruta $(\mathrm{PB})^{2}$ & 21,05 & 20,47 & 20,47 & 20,47 \\
\hline $\mathrm{NIDN}^{2}$ & 9,48 & 9,60 & 9,60 & 9,60 \\
\hline $\mathrm{NIDA}^{2}$ & 4,00 & 3,93 & 3,93 & 3,93 \\
\hline Extrato Etéreo $(E E)^{2}$ & 4,55 & 2,92 & 2,92 & 2,92 \\
\hline Carboidratos Totais $(\mathrm{CT})^{2}$ & 67,42 & 77,99 & 77,99 & 77,99 \\
\hline $\begin{array}{l}\text { Fibra em Detergente Neutro } \\
\left(\text { FDN) }{ }^{2}\right.\end{array}$ & 12,01 & 10,86 & 10,86 & 10,86 \\
\hline$(F D A)^{2}$ & 6,42 & 4,12 & 4,12 & 4,12 \\
\hline Carboidratos não fibrosos (CNF) ${ }^{2}$ & 54,41 & 67,13 & 67,13 & 67,13 \\
\hline $\mathrm{FDAi}^{2}$ & 1,00 & 1,03 & 1,03 & 1,03 \\
\hline Lignina $^{2}$ & 1,08 & 0,95 & 0,95 & 0,95 \\
\hline $\mathrm{NDT}^{2}$ & 84,02 & 80,66 & 80,66 & 80,66 \\
\hline ELL $(\text { Mcal } / \mathrm{kg})^{3}$ & 2,14 & 1,95 & 1,95 & 1,95 \\
\hline $\mathrm{EB}(\mathrm{cal} / \mathrm{g} / \mathrm{MS})^{3}$ & 3918,39 & 3607,82 & 3607,82 & 3607,82 \\
\hline
\end{tabular}


Tabela 4. Proporção dos ingredientes e composição bromatológica da ração experimental expressos na matéria seca (\%MS).

\begin{tabular}{|c|c|c|c|c|}
\hline \multirow{2}{*}{ Ingredientes (\%) } & \multicolumn{4}{|c|}{ Dietas experimentais } \\
\hline & $\mathrm{C}^{4}$ & $\mathrm{U}^{5}$ & UE $-1^{6}$ & UE-2 $2^{7}$ \\
\hline Silagem de Milho & 50,23 & 50,00 & 50,00 & 50,00 \\
\hline Fubá de milho & 31,23 & 44,16 & 44,16 & 44,16 \\
\hline Farelo de Soja & 10,66 & - & - & - \\
\hline Grão de soja & 5,88 & 1,70 & 1,70 & 1,70 \\
\hline Uréia & - & 2,00 & 2,00 & 2,00 \\
\hline Mistura Mineral & 1,99 & 1,98 & 1,98 & 1,98 \\
\hline Calcário & 0,11 & 0,11 & 0,11 & 0,11 \\
\hline Sal & 0,11 & 0,11 & 0,11 & 0,11 \\
\hline \multicolumn{5}{|l|}{ Composição química (\%MS) } \\
\hline Matéria Seca $(\mathrm{MS})^{1}$ & 62,95 & 62,89 & 62,89 & 62,89 \\
\hline Matéria Orgânica $(\mathrm{MO})^{2}$ & 93,68 & 92,21 & 92,21 & 92,21 \\
\hline Matéria Mineral $(\mathrm{MM})^{2}$ & 7,83 & 7,83 & 7,83 & 7,83 \\
\hline Proteína Bruta $(\mathrm{PB})^{2}$ & 15,34 & 15,07 & 15,07 & 15,07 \\
\hline $\mathrm{NIDN}^{2}$ & 13,98 & 14,01 & 14,01 & 14,01 \\
\hline $\mathrm{NIDA}^{2}$ & 7,06 & 7,01 & 7,01 & 7,01 \\
\hline Extrato Etéreo $(E E)^{2}$ & 3,62 & 2,81 & 2,81 & 2,81 \\
\hline Carboidratos Totais $(\mathrm{CT})^{2}$ & 75,31 & 80,55 & 80,55 & 80,55 \\
\hline Fibra em Detergente Neutro (FDN) ${ }^{2}$ & 32,33 & 31,66 & 31,66 & 31,66 \\
\hline Fibra em Detergente Ácido $(\mathrm{FDA})^{2}$ & 21,73 & 20,51 & 20,51 & 20,51 \\
\hline Carboidratos não fibrosos $(\mathrm{CNF})^{2}$ & 42,98 & 48,89 & 48,89 & 48,89 \\
\hline $\mathrm{FDAi}^{2}$ & 7,57 & 7,55 & 7,55 & 7,55 \\
\hline Lignina $^{2}$ & 2,84 & 2,77 & 2,77 & 2,77 \\
\hline $\mathrm{NDT}^{2}$ & 73,63 & 71,99 & 71,99 & 71,99 \\
\hline ELL $(\text { Mcal } / k g)^{3}$ & 1,72 & 1,62 & 1,62 & 1,62 \\
\hline $\mathrm{EB}(\mathrm{cal} / \mathrm{g} / \mathrm{MS})^{3}$ & 3898,66 & 3742,98 & 3742,98 & 3742,98 \\
\hline
\end{tabular}

Valor expresso em porcentagem da matéria natural; ${ }^{2}$ Valores expressos em porcentagem da matéria seca; ${ }^{3}$ Obtido com auxílio de bomba calorimétrica; ${ }^{4}$ Controle; ${ }^{5}$ Uréia pecuária; ${ }^{6} U$ réia encapsulada $1 ;{ }^{7}$ Uréia encapsulada 2.

O teor de proteína bruta (PB) foi obtido pelo produto da multiplicação do teor de nitrogênio total por 6,25 . Os carboidratos totais (CT) foram calculados segundo Sniffen et al. (1992), em que : CT- $100-$ (\% PB +\% EE +\% MM). Os teores de carboidratos não-fibrosos (CNF) foram estimados segundo Hall, (1998) onde: $\mathrm{CNF}=100-[(\% \mathrm{~PB}-\% \mathrm{~PB}$ Uréia + \% Uréia $)+\% \mathrm{EE}+\% \mathrm{MM}+$ $\%$ FDN]. 
Os nutrientes digestíveis totais foram calculados conforme equações do NRC (2001), em que: NDT $=$ CNFD + PBD + $(A G D * 2,25)+$ FDND - 7, onde PBD, CNFD, FDND e AGD representam o total destes nutrientes digestíveis. Os teores de fibra detergente neutro (FDN), fibra detergente neutro livre de cinza e proteína (FDNcp), e fibra detergente ácido (FDA) foram obtidos conforme método descrito por Van Soest et al. (1991), utilizando-se a-amilase e sem adição de sulfito de sódio na determinação do FDN, em Sistema Ankon®.

\subsubsection{Digestibilidade aparente total}

Para estimativa da digestibilidade aparente total dos nutrientes e da matéria seca, as amostras de fezes, silagem e sobras foram coletadas nos $8^{\circ}$, $9^{\circ}, 10^{\circ}$ e $11^{\circ}$ dias de cada período experimental. Os "pool" de amostras de cada animal foram acondicionados em sacos plásticos e armazenados em freezer à $-20{ }^{\circ} \mathrm{C}$. As amostras de silagem, sobras e fezes foram pré-secas em estufa com ventilação forçada $\left(60^{\circ} \mathrm{C} / 72\right.$ horas) e processadas em moinho de facas com peneiras de porosidade $2 \mathrm{~mm}$, já as amostras dos demais ingredientes da ração, farelo de soja, milho moído e grão de soja foram processados em moinho de facas com peneiras de porosidade $1 \mathrm{~mm}$.

A excreção total de fezes de cada animal foi estimada pela concentração do indicador interno de fibra em detergente ácido indigetível (FDAi).

$\mathrm{Na}$ avaliação das frações químicas dos componentes indigestíveis, utilizou-se 4 repetições de cada amostra pré-seca, as quais foram acondicionadas em sacos de tecido não-tecido (TNT- $100 \mathrm{~g} / \mathrm{m}^{2}$ ), com dimensões de $4 \times 5 \mathrm{~cm}$, segundo a relação de $20 \mathrm{mg}$ de matéria seca por centímetro quadrado de superfície (Nocek, 1988).

Segundo metodologia adaptada por Casali (2006), as amostras foram incubadas por 288 horas no rúmen de dois novilhos canulados da raça Nelore, previamente adaptados com concentrado a base de farelo de soja e milho moído e volumoso a base de silagem de milho 
Após a retirada do rúmen os sacos foram lavados com água corrente até o total clareamento desta, e imediatamente conduzidos à estufa de ventilação forçada (60\%/72 horas). Posteriormente, os sacos foram submetidos ao tratamento com detergente ácido (Mertens, 2002) por uma hora, em equipamento analisador de fibra Ankon®. Após este período foram lavados

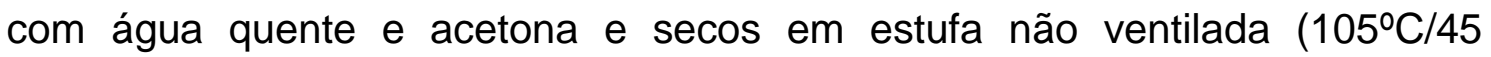
minutos), sendo retirados, acondicionados em dessecador (20 sacos/dessecador), e pesados obtendo-se ao final deste tratamento, a concentração de FDAi.

\subsubsection{Balanço de energia}

Para obtenção do consumo de energia bruta e realização do cálculo da eficiência do uso de energia consumida, as amostras de silagem, ingredientes e concentrados foram analisadas quanto ao seu teor de energia bruta em bomba calorimétrica, de acordo com Harvatine e Allen (2006). O consumo de energia digestível (CED) foi obtido por meio do coeficiente de digestibilidade das rações experimentais e do consumo de energia bruta, de acordo com os valores de energia obtidos para os ingredientes e a silagem de milho (Harvatine e Allen, 2006).

$O$ consumo de energia líquida (CEL), os valores de energia líquida de ganho $\left(E L_{g}\right)$ e mudança de peso de corpo vazio (MPCV) foram calculados de acordo com as equações do NRC (2000), a seguir: CEL (Mcal/dia) $=0,703 \times$ $\mathrm{EM}$ (consumo) $-0,19+\{[(0,097 \times \mathrm{EM}$ (consumo) $+0,19) / 97] \times[\mathrm{EE}-3]\} ; \mathrm{EM}$ $($ consumo $)=1,01 \times(\operatorname{ED}$ (consumo $)-0,45]+0,0046 \times(E E-3)$ onde: $E M=$ energia metabolizável; $\mathrm{EE}$ = extrato etéreo; $\mathrm{ED}=$ energia digestível.

Os valores de energia metabolizável (EM) foram obtidos pela seguinte fórmula: $\mathrm{EM} \quad(\mathrm{Mcal} / \mathrm{Kg})=\left[1,01^{*}\left\{(\% \mathrm{CNF} / 100)^{*} 4,2+\quad(\% \mathrm{FDN} / 100)^{*} 4,2+\right.\right.$ $\left.\left.\left.(\% \mathrm{~PB} / 100)^{\star} 5,6+(\% \mathrm{AG} / 100)^{*} 9,4-03\right)\right\}-0,45\right]+0,0046^{*}(\mathrm{EE}-3,0)$.

A mudança de peso de corpo vazio (MPCV) foi calculada a partir do peso vivo $(\mathrm{PV})$ onde: $\mathrm{PCV}=0,81^{*} \mathrm{PV}$. A energia líquida de ganho foi calculada 
através da fórmula: $\mathrm{EL}_{\mathrm{g}}=\mathrm{EL}$ (consumo) $-\mathrm{EL}$ (mantença) onde $\mathrm{EL}$ (mantença) $=(0,07)^{\star}\left(P V^{*} 0,85\right)^{0,75}$

A eficiência de utilização de energia para ganho de peso foi estimada a partir da relação entre os teores de energia líquida de ganho em função da EM da dieta, segundo Harvatine e Allen (2006).

\subsubsection{Balanço de nitrogênio}

Para o cálculo de balanço de nitrogênio foi realizada a determinação da concentração de creatinina na urina de acordo com metodologia descrita por Valadares et al. (1999) e Rennó (2003). As amostras spot de $50 \mathrm{~mL}$ de urina foram obtidas de todos os animais no 9 o dia de cada período experimental, quatro horas após a alimentação matinal, durante miçcão espontânea. As alíquotas de $50 \mathrm{~mL}$ de urina (amostra spot) foram filtradas e alíquotas de $10 \mathrm{~mL}$ foram diluídas imediatamente em $40 \mathrm{~mL}$ de ácido sulfúrico a 0,036 N para evitar destruição bacteriana dos derivados de purinas e precipitação do ácido úrico e foram armazenadas a $-15{ }^{\circ} \mathrm{C}$ para posteriores análises de ácido úrico e alantoína. Uma amostra de urina pura foi armazenada para determinação dos compostos nitrogenados totais, de uréia e creatinina.

As concentrações de creatinina foram determinadas por meio de kits comerciais (Laborlab®), utilizando reação enzimática calorimétrica cinética em aparelho SBA-200 CELM®. Para a realização dessa análise, $100 \mu \mathrm{L}$ de urina foram diluídos em $4.900 \mu \mathrm{L}$ de água deionizada. Os resultados obtidos foram calculados pela seguinte fórmula: Creatinina $(\mathrm{mg} / \mathrm{dL})=$ creatinina $(\mathrm{mg} / \mathrm{dL}){ }^{*} 0,020 * 50$ (Biggs e Copper, 1961).

O volume urinário total diário foi estimado dividindo-se as excreções urinárias diárias de creatinina pelos valores observados de concentração de creatinina na urina das amostras spot. Dessa forma, com a excreção média diária de creatinina e a concentração de creatinina $(\mathrm{mg} / \mathrm{dL})$ na amostra spot de urina, foi estimado o volume total diário de urina, em litros por animal/dia, para o cálculo do balanço de nitrogênio. 
O consumo de nitrogênio foi determinado retirando-se o valor de conversão de nitrogênio total das amostras para obtenção do valor de proteína bruta $(6,25)$, obtendo-se a quantidade em gramas de nitrogênio consumida. $O$ mesmo cálculo foi realizado com os valores de proteína bruta das fezes obtendo-se a excreção total de nitrogênio em $\mathrm{g} / \mathrm{kg} \mathrm{MS}$.

O nitrogênio total das amostras de urina foi determinado de acordo com as metodologias descritas por Silva e Queiroz (2002), onde a quantidade em gramas de nitrogênio para cada $100 \mathrm{~mL}$ de urina foi obtido dividindo-se o valor de proteína bruta das amostras pelo fator 6,25.

$O$ balanço de nitrogênio foi obtido subtraindo o total de nitrogênio em gramas consumido pelos valores de nitrogênio na urina e fezes, obtendo-se os valores de nitrogênio retido em gramas e em porcentagem de nitrogênio total.

\subsubsection{Fermentação ruminal}

As amostras de líquido ruminal foram coletadas no último dia de cada período, sendo uma coleta realizada antes da alimentação ( 0 hora), e seis coletas com intervalos de 2 horas após a alimentação (2, 4, 6, 8, 10 e 12 horas). Logo após a coleta foram determinados os valores de $\mathrm{pH}$ ruminal utilizando potenciômetro. As análises foram realizadas no Laboratório de Bioquímica e Fisiologia Animal do VNP- FMVZ-USP.

No laboratório as amostras foram centrifugadas a $2.000 \times \mathrm{g}$ por 15 minutos, $1 \mathrm{~mL}$ do sobrenadante foi colocado em tubo de ensaio e adicionandose $0,2 \mathrm{~mL}$ de ácido fórmico P.A., arrolhado e identificado e armazenado em congelador a $-20{ }^{\circ} \mathrm{C}$ para determinação de ácidos graxos de cadeia curta. Da mesma amostra $2 \mathrm{~mL}$ do sobrenadante foi pipetado e armazenado em tubos de ensaio contendo $1 \mathrm{~mL}$ de ácido sulfúrico a $1 \mathrm{~N}$, para posterior determinação da concentração de nitrogênio amoniacal $\left(\mathrm{N}-\mathrm{NH}_{3}\right)$.

A metodologia utilizada para análise de ácidos graxos de cadeia curta foi preconizada por Erwin et al. (1961), sendo utilizado cromatógrafo a gás (Modelo 9001 Gas Chromatograph, Marca Finnigan) equipado com coluna de vidro de 02 metros de comprimento x 1/4, empacotada com 80/120 Carbopack 
B-DA/4\% Carbowax 20M. Os gases utilizados foram o nitrogênio como gás de arraste na vazão de $25 \mathrm{~mL} /$ minuto, oxigênio como gás comburente na vazão de $175 \mathrm{~mL} /$ minuto, e hidrogênio como gás combustível na vazão de $15 \mathrm{~mL} /$ minuto. As temperaturas utilizadas do vaporizador foi de $220{ }^{\circ} \mathrm{C}$, do detector de ionização de chamas de $250{ }^{\circ} \mathrm{C}$ e da coluna de separação de $195{ }^{\circ} \mathrm{C}$ por 3 minutos, aumentando $10^{\circ} \mathrm{C} /$ minuto até $200^{\circ} \mathrm{C}$.

Soluções padrão a 0,1 Normal de ácido acético, propiônico e butírico foram preparadas e padronizadas com hidróxido de potássio $(\mathrm{KOH})$ 0,1 Normal, a fim de produzir solução padrão de ácidos graxos voláteis de concentração conhecida. As determinações foram realizadas injetando-se $1 \mu \mathrm{L}$ de amostra em cromatógrafo integrado a computador, que processava os cálculos de quantificação, utilizando-se do software BORWIN versão 1.21 para cromatografia.

$\mathrm{O}$ nitrogênio amoniacal $\left(\mathrm{N}-\mathrm{NH}_{3}\right)$ foi determinado pelo método de ácido salicílico. Foram adicionados aos tubos contendo amostras de líquido ruminal e ácido sulfúrico a $1 \mathrm{~N}, 1 \mathrm{~mL}$ de tungstato de sódio a $10 \%$, e posteriormente as amostras foram centrifugadas a $1.200 \times \mathrm{g}$ durante 15 minutos. Em seguida foram pipetados $25 \mu \mathrm{L}$ do sobrenadante a um tubo limpo e neste adicionados 5 $\mathrm{mL}$ do reagente fenol e $5 \mathrm{~mL}$ de hipoclorito.

Os tubos foram agitados para homogeneização das amostras e colocados em banho-maria a $37^{\circ} \mathrm{C}$ durante 15 minutos adquirindo coloração azul. Após resfriamento as amostras foram analisadas em espectofotômetro quanto a sua absorbância e os resultados obtidos foram utilizados em equação de regressão para calcular a concentração em $\mathrm{mg} / \mathrm{dL}$, onde: Concentração de $\mathrm{N}-\mathrm{NH}_{3}(\mathrm{mg} / \mathrm{dL})=$ Absorbância $-(\mathrm{a}) / \mathrm{b} ; \mathrm{b}=\mathrm{R}^{2}$ da equação elaborada a partir do padrão.

\subsubsection{Síntese de proteína microbiana}

As análises para determinação da síntese de proteína microbiana foram realizadas no Laboratório de Bioquímica e Fisiologia Animal do VNP-FMVZUSP. 
Alíquotas de $50 \mathrm{~mL}$ de urina (amostra spot) foram obtidas de todas os animais no 9 o dia do período experimental, aproximadamente 4 horas após a alimentação, durante micção espontânea. A urina foi filtrada e alíquotas de 10 $\mathrm{mL}$ foram diluídas imediatamente em $40 \mathrm{~mL}$ de ácido sulfúrico a $0,036 \mathrm{~N}$ para evitar destruição bacteriana dos derivados de purinas e precipitação do ácido úrico.

A excreção urinária diária de creatinina foi estimada a partir da excreção média diária, estabelecida de $27,76 \mathrm{mg} / \mathrm{Kg}$ de peso vivo para gado de corte (Rennó, 2003). Dessa forma, com a excreção média diária de creatinina e a concentração de creatinina $(\mathrm{mg} / \mathrm{dL})$ na amostra spot de urina, foi estimado o volume total diário de urina, em litros por animal/dia. As concentrações de alantoína na urina e os de ácido úrico na urina foram determinadas pelo método colorimétrico, conforme metodologia de Fujihara et al. (1987), descrita por Chen e Gomes (1992).

A excreção total de derivados de purinas foi calculada pela soma das quantidades de alantoína e ácido úrico excretadas na urina expressas em $\mathrm{mmol} / \mathrm{dia}$. As purinas microbianas absorvidas (Pabs, mmol/dia) foram calculadas a partir da excreção de derivados de purinas (DP, mmol/dia), por meio da equação Pabs $=\left(\mathrm{DP}-0,236^{*} \mathrm{PV}^{0,75}\right) / 0,84$, em que 0,84 é a recuperação de purinas absorvidas como derivados de purina e $0,236^{\star} \mathrm{PV}^{0,75}$, a excreção endógena de derivados de purina (Orellana Boero et al., 2001).

A síntese ruminal de compostos nitrogenados ( $\mathrm{Nmic}, \mathrm{gN} / \mathrm{dia}$ ) foi calculada com base nas purinas absorvidas (Pabs, mmol/dia), utilizando-se a equação (Chen e Gomes, 1992): Nmic $=\left(70^{*} \mathrm{Pabs}\right) /\left(0,83^{*} 0,134^{*} 1.000\right)$, em que 70 é o conteúdo de $\mathrm{N}$ nas purinas $(\mathrm{mgN} / \mathrm{mol}) ; 0,134$, a relação $\mathrm{N}$ purina: $\mathrm{N}$ total nas bactérias (Valadares et al., 1999); e 0,83, a digestibilidade intestinal das purinas microbianas.

\subsubsection{Parâmetros sanguíneos}

As coletas de sangue foram realizadas no $10^{\circ}$ dia de cada período experimental por punção da veia jugular, anteriormente ao fornecimento das 
rações no período da manhã. As amostras foram coletadas em tubos vacuolizados (vacutainer) de $10 \mathrm{~mL}$ para dosagem dos parâmetros sanguíneos glicose, colesterol total, proteínas totais, albumina, uréia e nitrogênio uréico, as enzimas aspartato aminotransferase (AST) e gama glutamil transferase (GTA).

Imediatamente após coleta as amostras foram coletadas refrigeradas e centrifugadas a 2000 x g durante 15 minutos, para a separação do soro. $\mathrm{O}$ centrifugado obtido foi transferido para tubetes plásticos, identificados e armazenados a $-20^{\circ} \mathrm{C}$, até o procedimento das análises laboratoriais.

As análises das concentrações dos parâmetros sanguíneos foram realizadas no Laboratório de Bioquímica e Fisiologia Animal do VNP-FMVZUSP, por meio de kits comerciais (Laborlab® e CELM®) que utilizam método enzimático colorimétrico de ponto final, sendo a leitura realizada em analisador automático de bioquímica sanguínea (Sistema de Bioquímica Automático SBA200 CELM®).

\subsubsection{Análises estatísticas}

Os dados obtidos foram submetidos à análise de variância e contraste ortogonal pelo comando PROC MIXED do programa Statistical Analysis System versão 9.2 (SAS, 2010), de acordo com o modelo estatístico:

$$
\text { Yijk }=\mu+Q i+A j+P y+T k+E i j k
$$

Onde: Yijk = variável dependente, $\mu=$ médias gerais, $\mathrm{Qi}=$ efeito de quadrado, $\mathrm{Aj}$ = efeito do animal $(\mathrm{i}=1 \mathrm{a} 8), \mathrm{Py}=$ efeito de período $(\mathrm{j}=1$ a 4$), \mathrm{Tk}$ = efeito de tratamento $(\mathrm{k}=1$ a 4$)$, e Eijk = erro. Foi considerado efeito aleatório animal dentro de quadrado.

Para avaliação dos efeitos de tratamentos foram considerados os seguintes contrastes ortogonais: $\mathrm{C} 1=$ dieta controle $(\mathrm{C})$ versos dietas com inclusão de ureia (U + UE1 + UE2); o objetivo foi comparar a dieta controle com as dietas com inclusão de uréia, seja ela pecuária ou encapsulada de liberação lenta; C2=dieta com inclusão de uréia convencional (U) versos dietas com inclusão de uréia encapsulada de liberação lenta; o objetivo foi avaliar as diferenças entre a uréia pecuária e as uréia encapsuladas de liberação lenta; 
C3 = dieta com inclusão da uréia de liberação lenta encapsulada com polímero 1 versos uréia de liberação lenta encapsulada com polímero 2; objetivo foi comparar as duas uréias encapsuladas de liberação lenta. Todos os valores obtidos foram submetidos a análise de variância com nível de $5 \%$ de significância. Os graus de liberdade calculados foram realizados de acordo com o método satterthwaite $(\mathrm{ddfm}=$ satterth). Os parâmetros de fermentação ruminal (AGCC, valores de $\mathrm{pH}$ e $\mathrm{N}-\mathrm{NH}_{3}$ ) foram submetidos ao comando REPEATED do PROC MIXED para avaliação de medidas repetidas no tempo. As médias dos tratamentos foram obtidas por meio do LSMEANS. A estrutura de Akaike foi utilizada o que permite maiores critérios de informação. Para as variáveis medidas ao longo do tempo, o modelo incluiu o tratamento (dieta), o tempo e a interação entre o tempo e o tratamento como efeitos fixos. Para todas as variáveis foi utilizado efeito aleatório de animal dentro do quadrado.

\subsection{Experimento 2}

\subsubsection{Local, Instalações e animais}

O experimento foi conduzido no Laboratório de Pesquisas em Bovinos de Leite (LPBL) do VNP-FMVZ-USP, situado no Campus Administrativo de Pirassununga, no período de 14 de Junho a 14 de Setembro de 2010.

A localização geográfica do campus da USP em Pirassununga é 21059 de latitude sul e 47026 de longitude oeste (W.Gr) e altitude média de 635 metros. O clima da região é tropical do tipo Cwa na classificação de Koppen, e a temperatura média anual é de $20,8^{\circ} \mathrm{C}$, com precipitação pluviométrica média anual de $1298 \mathrm{~mm}$.

Foram utilizados 84 animais machos inteiros, da raça Nelore, com idade aproximada de 18 meses e peso vivo inicial médio de $350 \mathrm{~kg}$. Os animais foram confinados por período de 84 dias, precedido de um período de adaptação, de 7 dias. Os animais foram agrupados em delineamento inteiramente casualizado 
em 7 piquetes; correspondentes a 7 (sete) dietas, formuladas para ganho de peso de $1,5 \mathrm{~kg} /$ dia segundo NRC (1996).

\subsubsection{Rações experimentais}

As dietas fornecidas aos animais em estudo foram compostas por sete rações durante todo o período experimental, formuladas para serem isonitrogenadas, isocalóricas e isoenxofre, de forma a atenderem as exigências nutricionais de novilhos em crescimento com ganho de peso corporal de aproximadamente $1,50 \mathrm{~kg} / \mathrm{dia}$, conforme recomendações do NRC (1996).

Os animais foram distribuídos aleatoriamente para receber as seguintes rações experimentais: 1) Controle (C), composta por ração sem a inclusão de uréia; 2) Uréia pecuária (Reforce N) (U-1), com a utilização de 1,0\% de uréia pecuária na ração, baseada na matéria seca; 3) Uréia pecuária (Reforce N) (U2), com a utilização de 2,0\% de uréia pecuária na ração, baseada na matéria seca; 4) Uréia encapsulada 1 (UE1-1), a utilização de 1,0\% de uréia encapsulada com o polímero 1 na ração, baseada na matéria seca; 5) Uréia encapsulada 1 (UE1-2), a utilização de 2,0\% de uréia encapsulada com o polímero 1 na ração, baseada na matéria seca; e 6) Uréia encapsulada 2 (UE21), com a utilização de $1,0 \%$ de uréia encapsulada com o polímero 2 na ração, baseada na matéria seca; e 7) Uréia encapsulada 2 (UE2-2), com a utilização de 2,0\% de uréia encapsulada com o polímero 2 na ração, baseada na matéria seca.

O volumoso oferecido foi a silagem de milho, sendo a proporção volumoso: concentrado da dieta de 50:50.

\subsubsection{Análise de alimentos}

Diariamente foram feitas as pesagens das quantidades dos volumosos e concentrados fornecidos e das sobras de cada tratamento. Os animais foram arraçoados uma vez no dia, às 7:00, de acordo com o consumo de matéria 
seca do dia anterior, de forma a ser mantido um porcentual diário de excedente da dieta, entre 5 e 10\% para que não houvesse limitação de consumo.

As duas porções constituintes da ração, concentrado e volumoso, foram misturadas no cocho e fornecidas na forma de dieta completa. A cada 7 (sete) dias era realizada a coleta e armazenamento a $20^{\circ} \mathrm{C}$ do pool de amostras de alimentos e sobras obtidos durante para posterior análise de nutrientes.

As análises químico-bromatológicas foram realizadas no Laboratório de Bromatologia do VNP-FMVZ-USP. A proporção dos ingredientes no concentrado e dieta total, assim como a respectiva composição bromatológica das rações experimentais, concentrados e ingredientes encontram-se nas Tabelas 5, 6 e 7 .

As análises químico-bromatológicas foram realizadas conforme descrito no experimento 1.

Tabela 5. Composição bromatológica dos ingredientes da dieta.

\begin{tabular}{|c|c|c|c|c|}
\hline Composição química & $\begin{array}{c}\text { Silagem de } \\
\text { Milho }\end{array}$ & $\begin{array}{l}\text { Farelo } \\
\text { de Soja }\end{array}$ & $\begin{array}{l}\text { Milho } \\
\text { Moído }\end{array}$ & $\begin{array}{c}\text { Grão de } \\
\text { Soja }\end{array}$ \\
\hline${\text { Matéria Seca }(\mathrm{MS})^{1}}^{1}$ & 34,76 & 90,21 & 89,89 & 95,32 \\
\hline Matéria Orgânica $(\mathrm{MO})^{2}$ & 94,32 & 94,05 & 98,38 & 94,46 \\
\hline Matéria Mineral $(\mathrm{MM})^{2}$ & 5,67 & 5,95 & 1,62 & 5,54 \\
\hline Proteína Bruta $(\mathrm{PB})^{2}$ & 9,68 & 50,67 & 8,90 & 39,04 \\
\hline $\mathrm{NIDN}^{2}$ & 18,43 & 4,88 & 10,20 & 17,27 \\
\hline $\mathrm{NIDA}^{2}$ & 10,09 & 2,75 & 4,20 & 6,60 \\
\hline Extrato Etéreo $(E E)^{2}$ & 2,70 & 2,48 & 2,51 & 20,73 \\
\hline Carboidratos Totais $(\mathrm{CT})^{2}$ & 83,11 & 40,90 & 86,97 & 34,69 \\
\hline Fibra em Detergente Neutro (FDN) ${ }^{2}$ & 52,46 & 12,61 & 11,64 & 17,01 \\
\hline Carboidrato não Fibroso (CNF) ${ }^{2}$ & 30,65 & 28,29 & 75,33 & 17,68 \\
\hline Fibra em Detergente Ácido (FDA) ${ }^{2}$ & 36,90 & 9,90 & 4,10 & 14,64 \\
\hline $\mathrm{FDAi}^{2}$ & 14,08 & 0,82 & 1,13 & 0,94 \\
\hline Lignina $^{2}$ & 4,59 & 0,89 & 0,99 & 2,26 \\
\hline $\mathrm{NDT}^{2}$ & 63,33 & 81,48 & 87,52 & 98,73 \\
\hline ELL $(\text { Mcal } / \mathrm{kg})^{3}$ & 1,30 & 2,30 & 2,10 & 2,80 \\
\hline $\mathrm{EB}(\mathrm{cal} / \mathrm{g} / \mathrm{MS})^{3}$ & 3878,63 & 4129,50 & 3891,25 & 5016,75 \\
\hline
\end{tabular}


Tabela 6. Proporção dos ingredientes e composição bromatológica dos concentrados experimentais expressos na matéria seca (\%MS).

\begin{tabular}{|c|c|c|c|c|c|c|c|}
\hline Ingredientes (\% MS) & \multicolumn{7}{|c|}{ Dietas experimentais } \\
\hline Farelo de soja & 21,42 & 7,05 & - & 7,05 & - & 7,05 & - \\
\hline Uréia & 0,00 & 1,83 & 4,00 & 1,83 & 4,00 & 1,83 & 4,00 \\
\hline Mistura Mineral & 3,99 & 3,99 & 4,00 & 3,99 & 4,00 & 3,99 & 4,00 \\
\hline Calcário & 0,21 & 0,21 & 0,21 & 0,21 & 0,21 & 0,21 & 0,21 \\
\hline \multicolumn{8}{|l|}{ Composição química } \\
\hline Matéria Seca (MS) & 91,39 & 91,06 & 91,06 & 91,06 & 91,06 & 91,06 & 91,06 \\
\hline Matéria Orgânica $(\mathrm{MO})^{2}$ & 93,02 & 92,04 & 90,11 & 92,04 & 90,11 & 92,04 & 90,11 \\
\hline Matéria Mineral $(\mathrm{MM})^{2}$ & 10.04 & 10,04 & 10,04 & 10,04 & 10,04 & 10,04 & 10,04 \\
\hline Proteína Bruta $(\mathrm{PB})^{2}$ & 21,05 & 20,15 & 20,47 & 20,15 & 20,47 & 20,15 & 20,47 \\
\hline $\mathrm{NIDN}^{2}$ & 9,48 & 9,93 & 9,60 & 9,93 & 9,60 & 9,93 & 9,60 \\
\hline $\mathrm{NIDA}^{2}$ & 4,00 & 4,09 & 3,93 & 4,09 & 3,93 & 4,09 & 3,93 \\
\hline Carboidratos não fibrosos $(\mathrm{CNF})^{2}$ & 54,41 & 62,03 & 67,13 & 62,03 & 67,13 & 62,03 & 67,13 \\
\hline $\mathrm{FDAi}^{2}$ & 1,00 & 1,02 & 1,03 & 1,02 & 1,03 & 1,02 & 1,03 \\
\hline Lignina $^{2}$ & 1,08 & 1,05 & 0,95 & 1,05 & 0,95 & 1,05 & 0,95 \\
\hline $\mathrm{NDT}^{2}$ & 84,02 & 83,17 & 80,66 & 83,17 & 80,66 & 83,17 & 80,66 \\
\hline ELL $(\text { Mcal } / \mathrm{kg})^{3}$ & 2,14 & 2,06 & 1,95 & 2,06 & 1,95 & 2,06 & 1,95 \\
\hline $\mathrm{EB}(\mathrm{cal} / \mathrm{g} / \mathrm{MS})^{3}$ & 3918,39 & 3795,10 & 3607,82 & 3795,10 & 3607,82 & 3795,10 & 3607,82 \\
\hline
\end{tabular}


Tabela 7. Proporção dos ingredientes e composição bromatológica das dietas experimentais expressos na matéria seca (\%MS).

\begin{tabular}{|c|c|c|c|c|c|c|c|}
\hline \multirow{2}{*}{ Ingredientes (\% MS) } & \multicolumn{7}{|c|}{ Dietas experimentais } \\
\hline & $\mathrm{C}^{4}$ & $\mathrm{U}-1 \%^{5}$ & $\mathrm{U}-2 \%^{6}$ & UE1-1\% ${ }^{7}$ & UE1-2\% ${ }^{8}$ & UE2-1\% ${ }^{9}$ & $\mathrm{UE} 2-2 \%^{10}$ \\
\hline Fubá de milho & 31,23 & 38,70 & 44,16 & 38,70 & 44,16 & 38,70 & 44,16 \\
\hline Grão de soja & 5,88 & 4,91 & 1,70 & 4,91 & 1,70 & 4,91 & 1,70 \\
\hline Uréia & 0,00 & 0,92 & 2,00 & 0,92 & 2,00 & 0,92 & 2,00 \\
\hline Mistura Mineral & 1,99 & 1,99 & 1,98 & 1,99 & 1,98 & 1,99 & 1,98 \\
\hline Calcário & 0,11 & 0,11 & 0,11 & 0,11 & 0,11 & 0,11 & 0,11 \\
\hline \multicolumn{8}{|l|}{ Composição química } \\
\hline Matéria Seca (MS) ${ }^{1}$ & 62,95 & 62,92 & 62,89 & 62,92 & 62,89 & 62,92 & 62,89 \\
\hline Matéria Orgânica $(\mathrm{MO})^{2}$ & 93,68 & 93,19 & 92,21 & 93,19 & 92,21 & 93,19 & 92,21 \\
\hline Matéria Mineral $(\mathrm{M} M)^{2^{\prime}}$ & 7,83 & 7,83 & 7,83 & 7,83 & 7,83 & 7,83 & 7,83 \\
\hline Proteína Bruta $(\mathrm{PB})^{2}$ & 15,34 & 14,98 & 15,07 & 14,98 & 15,07 & 14,98 & 15,07 \\
\hline $\mathrm{NIDN}^{2}$ & 13,98 & 14,18 & 14,01 & 14,18 & 14,01 & 14,18 & 14,01 \\
\hline $\mathrm{NIDA}^{2}$ & 7,06 & 7,09 & 7,01 & 7,09 & 7,01 & 7,09 & 7,01 \\
\hline Carboidratos não fibrosos (CNF) ${ }^{2}$ & 42,98 & 46,34 & 48,89 & 46,34 & 48,89 & 46,34 & 48,89 \\
\hline $\mathrm{FDAi}^{2}$ & 7,57 & 7,55 & 7,55 & 7,55 & 7,55 & 7,55 & 7,55 \\
\hline Lignina $^{2}$ & 2,84 & 2,82 & 2,77 & 2,82 & 2,77 & 2,82 & 2,77 \\
\hline $\mathrm{NDT}^{2}$ & 73,63 & 73,26 & 71,99 & 73,26 & 71,99 & 73,26 & 71,99 \\
\hline $\operatorname{ELL}(\mathrm{Mcal} / \mathrm{kg})^{3}$ & 1,72 & 1,68 & 1,62 & 1,68 & 1,62 & 1,68 & 1,62 \\
\hline $\mathrm{EB}(\mathrm{cal} / \mathrm{g} / \mathrm{MS})^{3}$ & 3898,66 & 3837,32 & 3742,98 & 3837,32 & 3742,98 & 3837,32 & 3742,98 \\
\hline
\end{tabular}

Valor expresso em porcentagem da matéria natural; ${ }^{2}$ Valores expressos em porcentagem da matéria seca; ${ }^{3} \mathrm{Obtido}$ com auxílio de bomba calorimétrica; ${ }^{4} \mathrm{C}=\mathrm{C}$ Controle; ${ }^{5} \mathrm{U}$ -

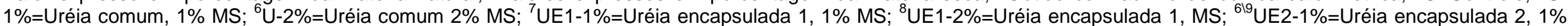
MS; ${ }^{10}$ UE2-2\%=Uréia encapsulada $2,2 \%$ MS. 


\subsubsection{Desempenho e qualidade de carcaça}

Os animais foram pesados antes do inicio do período experimental para mensurar o peso inicial dos animais e nos dias $28^{\circ}, 56^{\circ}$ e no $84^{\circ}$ do experimento para acompanhar o ganho de peso e peso final. Após 84 dias de experimento, os animais foram transportados para frigorífico comercial, sob Inspeção Federal, onde foram abatidos, por meio de insensibilização por pistola pneumática e posterior sangria. Após o abate, as carcaças permaneceram por 24 horas em câmara fria para estabelecimento do rigor mortis.

Após $24 \mathrm{~h}$ foi realizada a desossa e foi avaliado a área de olho de lombo $\left(A O L \mathrm{~cm}^{2}\right.$ ) e espessura de gordura subcutânea (EGS $\mathrm{mm}$ ) do músculo Longissimus da carcaça direita de cada animal, com auxílio de uma régua quadriculada específica.

\subsubsection{Parâmetros sanguíneos}

Foram realizadas coletas de sangue nos dias $28^{\circ}, 56^{\circ}$, e $84^{\circ}$ por punção da veia e/ou artéria coccídea, anteriormente ao fornecimento da dieta no período da manhã. As amostras foram coletadas (vacutainer) para dosagem dos parâmetros sanguíneos glicose, colesterol total, colesterol-HDL, proteínas totais, albumina, uréia e nitrogênio uréico e a enzimas aspartato aminotransferase (AST) no plasma.

Imediatamente após coleta as amostras foram refrigeradas $\mathrm{e}$ centrifugadas a $2000 \times$ g durante 15 minutos, para a separação do soro ou plasma e em seguida armazenados a $-2 \stackrel{\circ}{\circ}$, até o procedimento das análises laboratoriais.

As análises das concentrações dos parâmetros sanguíneos foram realizadas no Laboratório de Bioquímica e Fisiologia Animal do Departamento de Nutrição e Produção Animal da FMVZ-USP, por meio de kits comerciais (Laborlab® e CELM®). Foi utilizado o método enzimático colorimétrico de 
ponto final, sendo a leitura realizada em analisador automático de bioquímica sanguínea (Sistema de Bioquímica Automático SBA-200 CELM®).

\subsubsection{Análises estatísticas}

Os dados foram analisados utilizando-se o procedimento PROC MIXED (SAS, Versão 9.2, Institute Cary, NC 2010), de acordo com o seguinte modelo estatístico:

$$
Y i j=\mu+D i+T j+D i(T j)+e i j
$$

Onde: Yij = variável dependente, $\mu=$ média geral, $\mathrm{Di}=$ efeito da dieta $(\mathrm{i}=1 \mathrm{a}$ 7), $\mathrm{Tj}$ = efeito de dias em confinamento, $\mathrm{Di}(\mathrm{Tj})=$ efeito da interação entre dias da dieta e confinamento e eij = erro, Os graus de liberdade calculados foram realizados de acordo com o método satterthwaite (ddfm = satterth). Os dados obtidos foram submetidos à análise de variância e Contraste ortogonal pelo comando PROC MIXED do SAS, versão 9,2 (SAS, 2010), adotando-se nível de significância de $5 \%$.

Para avaliação dos efeitos de tratamentos foram considerados os seguintes contrastes ortogonais: $\mathrm{C} 1=$ dieta controle $(\mathrm{C})$ versos dietas com inclusão de uréia (U1 + U2 + UE1-1 + UE1-2 + UE2-1 + UE2-2); o objetivo foi comparar a dieta controle com as dietas com inclusão de uréia, seja ela pecuária ou encapsulada de liberação lenta; $\mathrm{C} 2=$ dieta com inclusão de uréia pecuária (U) versos dietas com inclusão de uréia encapsulada de liberação lenta; o objetivo foi avaliar as diferenças entre a uréia pecuária e as uréia encapsuladas de liberação lenta; C3 = dieta controle versus dietas com 1\% de inclusão de uréia; C4 = dieta controle versus dietas com $2 \%$ de inclusão de uréia; C5 = dietas com inclusão de 1\% de uréia versus dietas com inclusão de 2\% de uréia; C6 = dieta com inclusão da uréia de liberação lenta encapsulada com polímero 1 versos uréia de liberação lenta encapsulada com polímero 2. O LSMEANS foi utilizado para obtenção das médias ajustadas dos tratamentos. 


\section{Resultados e Discussão}

\subsection{Experimento 1}

\subsubsection{Consumo e digestibilidade aparente total}

Foi observado maior consumo de matéria seca $(\mathrm{kg} / \mathrm{dia})(\mathrm{P}<0,05)$ para os animais que receberam a dieta controle quando comparados aos animais que receberam dieta contendo uréias, e observou-se também maior consumo dos demais nutrientes (MO, PB, EE, CNF, FDN, NDT) (Tabela 8).

O menor consumo dos animais alimentados com as dietas contendo uréia contradiz com os resultados encontrados por Rennó et al. (2005), Paixão (2004), Magalhães (2003), Coutinho Filho (1995) e Obeid et. al. (1980) onde não observaram diferença no consumo entre os tratamentos com e sem uréia.

Galina et al. (2003) ao comparar dietas com e sem uréia, onde a fonte de uréia utilizada foi de liberação lenta, observou aumento de consumo de matéria seca e dos demais nutrientes nos animais alimentados com dietas contendo uréia. Já, Clarindo (2008) fornecendo níveis crescente de uréia (0; 0,$4 ; 0,75$ e 1,3\%) e Feijó et al. (1997) substituindo farelo de soja por uréia (0, 50 e 100\%), observaram menor consumo de matéria seca e dos demais nutrientes. Wilson et al. (1975), fornecendo níveis crescentes de uréia $(1,0$; 1,$65 ; 2,30$ e 3,0\% na MS total) concluíram que a uréia parece deprimir o consumo quando é incluída na dieta em níveis acima de 2\%. Esses autores atribuíram esse comportamento ao sabor amargo da uréia e, conseqüentemente, à sua baixa palatabilidade.

No presente estudo o fato das dietas com uréia terem apresentado menor consumo deve estar correlacionado com a quantidade de inclusão de uréia em relação à matéria seca da dieta, provavelmente devido a baixa palatabilidade quando em altas concentrações na dieta (2\%), pois nos estudos citados a cima onde o consumo não foi alterado ou mesmo aumentou, o nível de inclusão da dieta foi de no máximo de $1,95 \%$ da matéria seca da dieta.

Salman et al. (1996) sugerem que o uso de uréia pelos ruminantes acima de $1 \%$ da matéria seca da dieta total limita o consumo pela baixa 
patabilidade. Galo et al. (2003) ao testar diferentes níveis de inclusão de uréia na dieta de vacas leiteiras observaram diminuição do consumo dos animais quanto maior foi a inclusão de uréia. Segundo Bloomfield et al. (1960), a taxa de hidrólise da uréia no rúmen ocorre quatro vezes mais rápida do que a utilização da amônia pelos microrganismos, e segundo o autor se a inclusão da uréia estiver alta esse processo é intensificado, alterando a taxa de fermentação, digestibilidade do alimento e alterando o consumo.

Não foi observado efeito $(P>0,05)$ para todas as variáveis de consumo (MS, MO, PB, EE, CNF, FDN, NDT) quando avaliados os animais que foram alimentados com dietas contendo uréia comum e comparados aos animais alimentados com os dois tipos de uréia encapsulada. Ainda, não foram encontrados efeitos para todas as variáveis de consumo, a exceção a variável de consumo de proteína bruta $(\mathrm{kg} / \mathrm{dia})(\mathrm{P}<0,05)$ quando analisou os animais que foram alimentados com a dieta contendo a uréia encapsulada 1 em relação aos alimentados com a dieta contendo a uréia encapsulado do tipo 2. Este fato, provavelmente, deve estar correlacionado a fatores intrínsecos do tipo de uréia e sua tecnologia de liberação, e ao seu revestimento.

Foi observada tendência para a variável consumo de matéria seca em relação à porcentagem do peso vivo (\%PV) $(\mathrm{P}=0,052)$, onde animais que receberam a dieta controle apresentaram valor médio maior quando comparado ao valor médio de consumo dos animais que receberam dieta contendo uréia. Este fato como já discutido acima, deve estar correlacionado a diminuição do consumo dos animais que recebiam dieta contendo alta inclusão de uréia $(2 \%)$ em relação à matéria seca da dieta. 
Tabela 8. Consumos e digestibilidade aparente total de matéria seca e nutrientes em função das dietas experimentais.

\begin{tabular}{|c|c|c|c|c|c|c|c|c|}
\hline \multirow{2}{*}{ Variável } & \multicolumn{4}{|c|}{ Dietas experimentais } & \multirow{2}{*}{ EPM } & \multicolumn{3}{|c|}{ Contrastes } \\
\hline & $\mathrm{C}^{1}$ & $\mathrm{U}^{2}$ & UE-1 ${ }^{3}$ & UE-2 $2^{4}$ & & $\mathrm{C} 1$ & $\mathrm{C} 2$ & C3 \\
\hline \multicolumn{9}{|l|}{ Consumo (kg/dia) } \\
\hline Matéria seca (MS) & 8,46 & 7,90 & 8,04 & 7,55 & 0,22 & $\mathbf{0 , 0 2 9}$ & 0,703 & 0,125 \\
\hline Matéria orgânica (MO) & 7,95 & 7,27 & 7,39 & 6,99 & 0,20 & 0,006 & 0,743 & 0,156 \\
\hline Proteína bruta $(\mathrm{PB})$ & 1,31 & 1,21 & 1,23 & 1,12 & 0,03 & $\mathbf{0 , 0 1 3}$ & 0,414 & $\mathbf{0 , 0 4 5}$ \\
\hline Extrato etéreo (EE) & 0,32 & 0,24 & 0,24 & 0,23 & 0,01 & $<0,001$ & 0,383 & 0,206 \\
\hline Carboidrato não fibroso (CNF) & 3,51 & 3,25 & 3,29 & 3,10 & 0,10 & 0,013 & 0,615 & 0,130 \\
\hline Fibra em detergente neutro (FDN) & 2,79 & 2,55 & 2,62 & 2,53 & 0,06 & 0,041 & 0,807 & 0,489 \\
\hline Nutrientes digestíveis totais (NDT) & 6,28 & 5,69 & 5,77 & 5,44 & 0,16 & 0,001 & 0,634 & 0,110 \\
\hline \multicolumn{9}{|l|}{ Consumo (\%PV) } \\
\hline Matéria seca & 1,74 & 1,64 & 1,67 & 1,57 & 0,04 & $\mathbf{0 , 0 5 2}$ & 0,690 & 0,114 \\
\hline Fibra em detergente neutro & 0,57 & 0,53 & 0,54 & 0,52 & 0,01 & 0,061 & 0,905 & 0,473 \\
\hline \multicolumn{9}{|l|}{ Digestibilidade Aparente Total (\%) } \\
\hline Materia seca & 66,48 & 70,03 & 66,16 & 72,31 & 1,13 & 0,133 & 0,703 & $\mathbf{0 , 0 1 7}$ \\
\hline Matéria orgânica & 69,20 & 71,47 & 67,64 & 74,51 & 1,17 & 0,338 & 0,857 & $\mathbf{0 , 0 1 3}$ \\
\hline Proteína bruta & 64,14 & 73,49 & 67,49 & 73,83 & 1,24 & $<0,001$ & 0,117 & 0,005 \\
\hline Extrato etéreo & 86,07 & 85,28 & 87,56 & 89,03 & 1,01 & 0,541 & 0,165 & 0,550 \\
\hline Carboidratos totais & 69,37 & 70,61 & 66,81 & 74,03 & 1,22 & 0,626 & 0,937 & $\mathbf{0 , 0 1 7}$ \\
\hline Fibra em detergente neutro & 58,85 & 61,80 & 57,19 & 61,87 & 1,17 & 0,564 & 0,394 & 0,135 \\
\hline Carboidrato não fibroso & 77,81 & 77,39 & 74,20 & 84,14 & 1,68 & 0,796 & 0,574 & $\mathbf{0 , 0 1 2}$ \\
\hline $\mathrm{NDT}_{\mathrm{OBS}}$ & 69,81 & 73,85 & 70,10 & 77,49 & 1,24 & 0,076 & 0,979 & $\mathbf{0 , 0 1 0}$ \\
\hline
\end{tabular}

'Controle; ${ }^{2}$ Ureia pecuária; ${ }^{3}$ Uréia encapsulada $1 ;{ }^{4}$ Uréia encapsulada 2. C1= Controle vs Fontes Uréia; $\mathrm{C} 2=$ Uréia encapsuladas Vs Ureia pecuária; C3 = UE-1xUE-2.

Não foram observadas diferenças na digestibilidade aparente total dos nutrientes $(P>0,05)$, e na exceção da proteína bruta $(P<0,05)$, nos animais alimentados com a dieta controle quando comparados aos animais que receberam as dietas contendo uréia. O aumento verificado na digestibilidade da PB pode ser explicado pelo fato da uréia ser considerada $100 \%$ digestível. Assim, a substituição da proteína do farelo de soja pela uréia provocou melhora na digestibilidade aparente da PB da dieta. Segundo Huntingtons e Archibeque (1999), o efeito positivo da inclusão de uréia na dieta de ruminantes sobre a digestibilidade dos nutrientes ocorrem em função da capacidade dos microrganismos ruminais em assimilar os produtos da fermentação. Este resultado vai de encontro ao encontrado por Magalhães (2003), que observou o 
aumento linear da digestibilidade de MS e PB em função dos níveis de inclusão de uréia. Porém, contradiz aos achados de Hennessy et al. (1995), e Cecava e Archibeque (1999), que não observaram influência da inclusão de uréia sobre a digestibilidade de proteína bruta, assim como Rennó et al. (2005). Paixão (2004) reportou que a inclusão de uréia aumentou a digestibilidade dos carboidratos não fibrosos, e Silveira et al. (2008) reportou um aumento da digestibilidade de FDN no tratamento com farelo de soja quando comparado aos tratamentos que continham diferentes níveis de uréia.

Ainda, não foi observada diferença na digestibilidade aparente total dos nutrientes $(P>0,05)$ quando foram analisados os animais que foram alimentados com dietas contendo uréia comum e comparados aos animais alimentados com os dois tipos de uréia encapsulada. Este resultado contradiz aos achados de Xin et al. (2010), que observaram maior digestibilidade aparente total para proteina bruta e matéria seca em animais tratados com dietas contendo uréia encapsulada quando comparado a animais que foram alimentados com dietas contendo uréia pecuária. Também de forma semelhante Puga et al. (2001) e Galina et al. (2003) observaram maior digestibilidade aparente de MS, FDN e MO nos animais tratados com dietas contendo uréia encapsulada quando comparado aos animais que receberam dieta com uréia comum. Este aumento na digestibilidade observado por esses autores, segundo eles, deve-se ao fato de uma melhor atividade de fermentação da fibra no rúmen, onde a uréia encapsulada melhora o desequilíbrio de nutrientes para as bactérias do rúmen, fornecendo assim mais moduladamente $\mathrm{NH}_{3}$, e obtendo melhor sincronia da utilização do NNP e energia pelos microrganismos, melhorando a eficiência de síntese microbiana.

Foram observadas diferenças na digestibilidade aparente total de todos os nutrientes $(P<0,05)$, a exceção do extrato etéreo e da fibra em detergente neutro quando analisou os animais que foram alimentados com a dieta contendo a uréia encapsulada 1 em relação aos alimentados com a dieta contendo a uréia encapsulado do tipo 2. Este fato, provavelmente, deve estar correlacionado a fatores intrínseco ao tipo de uréia e sua tecnologia de liberação, e ao seu revestimento. 


\subsubsection{Fermentação ruminal}

Não foi observada diferença na concentração de $\mathrm{N}-\mathrm{NH}_{3}$ ruminal $(P>0,05)$ nos animais que receberam a dieta controle quando comparados aos animais que receberam dietas contendo uréia (Tabela 9). Segundo Bloomfield et al. (1960), a taxa de hidrolise da uréia no rúmen ocorre 4 vezes mais rápido do que a utilização pelos microrganismos, assim sua transformação em amônia no rúmen através da enzima urease é imediata, fazendo com que os níveis de amônia se elevem muito rapidamente, logo é de se esperar que a concentração de nitrogênio amoniacal aumente em função da inclusão de uréia. Ainda, Huntington e Archibeque (1999) verificaram que a taxa de produção de $\mathrm{N}-\mathrm{NH}_{3}$ no rúmen reflete a solubilidade e a fermentabilidade da dieta, bem como a produção endógena de compostos nitrogenados, logo dietas que contenha NNP como fonte de PDR apresenta concentrações maiores de nitrogênio amoniacal. Ainda, segundo Owens e Zinn (1988), o pico de nitrogênio amoniacal em dietas contendo uréia comum ocorre até $2 \mathrm{~h}$ após a alimentação e em dietas com baixa quantidade de PDR, como é o caso da dieta controle com farelo de soja, esse pico ocorre por volta de 4h após a alimentação, mas em concentrações menores. No caso de presente estudo não foram observadas diferenças entre as concentrações de nitrogênio amoniacal da dieta controle e das contendo uréia, provavelmente, pelo fato de as médias das dietas contendo uréia encapsulada serem próximas a média da dieta controle, fazendo que não desse diferença estatística. 
Tabela 9. Fermentação ruminal de acordo com as fontes de uréia utilizadas nas dietas experimentais.

\begin{tabular}{|c|c|c|c|c|c|c|c|c|c|c|c|}
\hline \multirow{2}{*}{ Vari vel } & \multicolumn{4}{|c|}{ Dietas experimentais } & \multirow{2}{*}{ EPM } & \multicolumn{6}{|c|}{ Valor de $P^{5}$} \\
\hline & $\mathrm{C}^{1}$ & $\square^{2}$ & $\mathrm{E} \square^{3}$ & $\mathrm{E} 2^{4}$ & & Trat & Tempo & nt & $\mathrm{C} 1$ & $\mathrm{C} 2$ & C3 \\
\hline $\mathrm{p} \square$ & 6,42 & 6,45 & 6,41 & 6,40 & 0,05 & 0,668 & $<0,001$ & 0,051 & 0,980 & 0,247 & 0,644 \\
\hline $\begin{array}{l}\mathrm{N} \square_{3} \\
\text { (mg dl) }\end{array}$ & 17,90 & 24,02 & 20,69 & 16,38 & 1,60 & 0,002 & $<0,001$ & 0,365 & 0,138 & 0,003 & 0,038 \\
\hline \multicolumn{12}{|c|}{ cidos graxos cadeia curta ( $\mathrm{mol}]$ ) } \\
\hline Total $\mathrm{A} \square \mathrm{V}$ & 114,92 & 110,81 & 113,06 & 110,07 & 2,89 & 0,318 & $<0,001$ & 0,908 & 0,148 & 0,651 & 0,268 \\
\hline Acetato & 78,27 & 75,95 & 76,87 & 74,70 & 1,84 & 0,252 & $<0,001$ & 0,947 & 0,109 & 0,947 & 0,219 \\
\hline Propionato & 24,85 & 23,43 & 25,15 & 24,40 & 0,84 & 0,115 & $<\mathbf{0}$, & 0,874 & 0,648 & 0,026 & 0,376 \\
\hline Butirato & 11,79 & 11,42 & 11,04 & 10,97 & 0,50 & 0,530 & $<0,001$ & 0,842 & 0,232 & 0,385 & 0,888 \\
\hline \multicolumn{12}{|c|}{ cidos graxos cadeia curta ( $\%$ total) } \\
\hline Acetato & 68,42 & 68,87 & 68,26 & 68,21 & 0,45 & 0,358 & $<0,001$ & 0,985 & 0,795 & 0,077 & 0,926 \\
\hline Propionato & 21,46 & 20,99 & 22,07 & 21,85 & 0,35 & 0,023 & $<0,001$ & 0,966 & 0,429 & 0,003 & 0,623 \\
\hline Butirato & 10,11 & 10,12 & 9,65 & 9,93 & 0,29 & 0,607 & $<0,001$ & 0,765 & 0,573 & 0,300 & 0,508 \\
\hline ela ão A P & 3,24 & 3,36 & 3,14 & 3,20 & 0,07 & 0,025 & $<0,001$ & 0,992 & 0,728 & 0,003 & 0,499 \\
\hline
\end{tabular}

Controle; ${ }^{2}$ Ureia pecuária; ${ }^{3}$ Uréia encapsulada $1 ;{ }^{4}$ Uréia encapsulada $2 .{ }^{2}$ Valor de $P$ observado para tratamento (Trat), tempo (T) e interação tratamento vs. tempo (Trat x T), C1= Controle vs Fontes Uréia; C2 = Uréia encapsuladas Vs Ureia pecuária; C3 = UE-1xUE-2.

Foi observada maior concentração de $\mathrm{N}-\mathrm{NH}_{3}$ ruminal $(P<0,05)$ nos animais que receberam a dieta com uréia pecuária quando comparados aos os animais que foram alimentados com os dois tipos de uréia encapsulada (Tabela 9).

Esse resultado vai contra aos achados Pires et al (2004) e Oliveira Jr. et al. (2004), que ao utilizarem amiréia como fonte de uréia de liberação lenta e não encontraram diferenças de concentrações ao comparar os resultados com as dietas que continha apenas uréia. Porém, Taylor-Edwards et al. (2009) e Xin et al. (2010) acharam resultados similares aos observados nesse experimento, onde animais que receberam dietas contendo uréia de liberação lenta quando comparadas a animais que receberam dietas contendo uréia pecuária apresentaram menores concentrações de $\mathrm{N}-\mathrm{NH}_{3}$ ruminal.

Segundo, Taylor-Edwards et al. (2009) a uréia pecuária sofreu hidrolise rápida no rúmen gerando concentrações de $\mathrm{N}-\mathrm{NH}_{3}$ ruminal $263 \%$ maiores nos animais tratados com uréia pecuária do que nos tratados com uréia encapsulada,e ainda, as concentrações de $\mathrm{N}-\mathrm{NH}_{3}$ ruminal do tratamento com uréia pecuária subiu de forma acentuada em $0,5 \mathrm{~h}$ após a administração mostrando que o processo de encapsulamento realmente foi efetivo, na 
liberação de uréia, fazendo com que a as bactérias ruminais pudessem

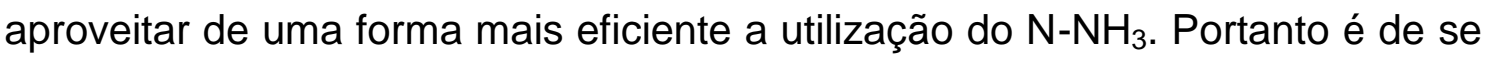
esperar que o encapsulamento nas uréias deste experimento, provavelmente esteja sendo eficiente em modular a liberação de nitrogênio no rúmen.

Foi observada maior concentração de $\mathrm{N}-\mathrm{NH}_{3}$ ruminal $(P>0,05)$ entre os animais que foram alimentados com a dieta contendo a uréia encapsulada 1 em relação aos alimentados com a dieta contendo a uréia encapsulado do tipo 2. Este fato, provavelmente, deve estar correlacionado a concentração de nitrogênio, a fator intrínseco no seu encapsulamento, ou seja, ao tipo de uréia e sua tecnologia de liberação, e a sua proporção de revestimento.

Não foi observada diferença nos valores de $\mathrm{pH}$ ruminal quando comparou os animais que receberam a dieta controle quando comparados aos animais que receberam dietas contendo uréia, nem entre os animais que receberam a dieta com uréia pecuária quando comparados aos os animais que foram alimentados com os dois tipos de uréia encapsulada, e nem entre os animais que foram alimentados com a dieta contendo a uréia encapsulada 1 em relação aos alimentados com a dieta contendo a uréia encapsulado do tipo 2.

Em todos os parâmetros mensurados observou-se efeito de tempo $(\mathrm{P}<0,05)$ e este fato está correlacionado a quantidade de coleta realizada de liquido ruminal (6 coletas), ao intervalo de tempo entre as coletas (a cada $2 \mathrm{~h}$ ) e ao comportamento da fermentação ruminal das dietas. Segundo Church (1979) ruminantes ao consumir dietas à base de volumoso mantem o pH ruminal entre 6,2 e 6,8, ao passo que aqueles que consumem concentrado, entre 5,8 e 6,6. Mould et al. (1983) demonstrou que o efeito de pH é bifásico. Na primeira fase, pode haver acidificação de 6,8 para 6,0, provocando redução na digestão da porção fibrosa do alimento. Após o $\mathrm{pH}$ do ambiente ruminal alcançar valores de 6,0; segunda fase, pode ocorrer uma parada na digestão devido à sensibilidade das bactérias fibrolíticas neste nível de acidez.

Não foram observadas diferenças nas porcentagens de ácidos acético e butírico $(P<0,05)$ quando comparados os animais que receberam a dieta controle em relação aos animais que receberam dietas contendo uréia. Também nos animais que receberam a dieta com uréia pecuária quando 
comparados aos animais que foram alimentados com os dois tipos de uréia encapsulada não apresentaram alterações nos parâmetros, assim como entre os animais que foram alimentados com a dieta contendo a uréia encapsulada 1 em relação aos alimentados com a dieta contendo a uréia encapsulado do tipo 2. Ainda, não foram observadas diferenças nas concentrações de ácidos acético, butírico e no total de ácidos graxos voláteis $(\mathrm{mol} / \mathrm{l})(\mathrm{P}<0,05)$ quando comparou os animais que receberam a dieta controle em relação aos animais que receberam as dietas experimentais.

Foram observadas menores proporções molares de ácido propiônico e concentrações de ácido propiônico (mol/L) e menor relação acetato/propionato nos animais alimentados com a dieta com uréia pecuária quando comparados aos animais alimentados com os dois tipos de uréia encapsulada. Este resultado contradiz o estudo de Xin et al. (2010), que comparou dietas contendo diferentes fontes proteícas (Proteína isolada da soja, uréia pecuária e uréia encapsulada) em vacas leiteiras e não observaram diferenças na concentração de AGV totais entre os três tratamentos, mas as porcentagens molares dos AGV individuais foram significativamente alterados pelos tratamentos dietéticos, onde dietas a base de uréia resultaram em uma maior proporção de acetato e menores de propionato que a dieta com farelo de soja, o que causou um aumento na relação acetato:propionato.

Foi observado efeito das dietas experimentais sobre a concentração de amônia ruminal, porcentagem de ácido propionico e na relação de acetato e propionato $(P<0,05)$.

\subsubsection{Síntese de proteína microbiana}

Não foram observadas diferenças nas concentrações (mmol/dia) de alantoína, ácido úrico, derivados de purina, purinas absorvíveis, compostos nitrogenados microbianos, creatina spot, volume urinário (L/dia), na quantidade de nitrogênio microbiano ( $\mathrm{g} / \mathrm{dia}$ ), na relação alantoína, nos derivados de purina e na eficiência de síntese de proteína microbiana $(P>0,05)$ quando comparadas as dietas experimentais. (Tabela 10) 
Os valores encontrados para os derivados de purinas na urina $e$ alantoína são inferiores das médias aos encontrados por Rennó et al. (2003) $(167,78 \mathrm{mmol} / \mathrm{dia})$ e Magalhães (2003) $(162,45 \mathrm{mmol} / \mathrm{dia})$ quando avaliaram diferentes níveis de inclusão de uréia. Ainda, os valores encontrados para purinas microbianas absorvíveis também foram inferiores aos encontrados por esses autores.

Tabela 10. Síntese de proteína microbiana de acordo com as fontes de uréia utilizadas nas dietas experimentais.

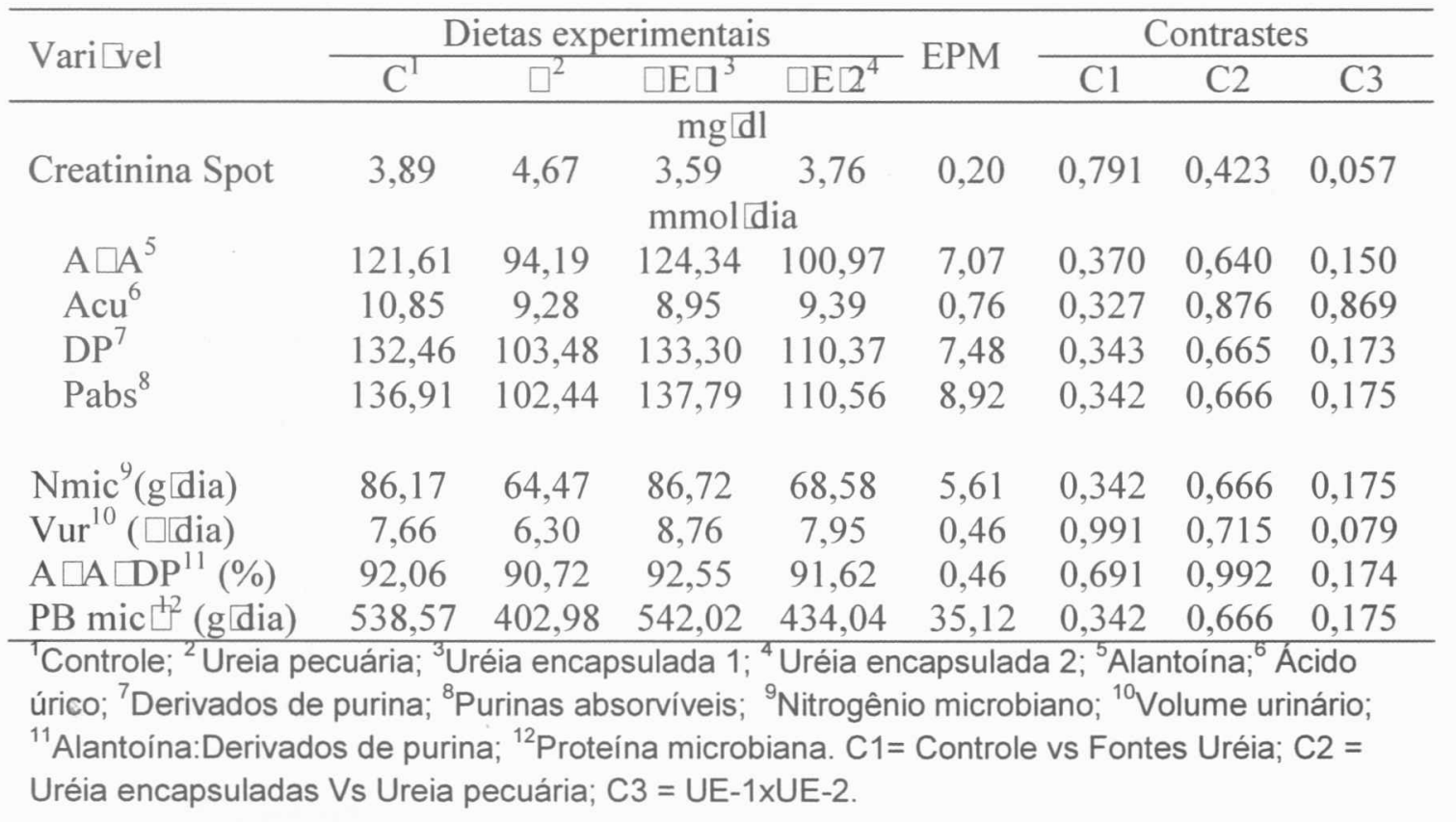

\subsubsection{Balanço energético}

Foram observadas diferenças no consumo (Mcal/d) de EB, ED e $E L_{L}$ $(\mathrm{P}<0,05)$ nos animais alimentados com a dieta controle quando comparados aos animais que receberam as dietas contendo uréia (Tabela 11). Estes resultados convergem com os resultados observados na tabela de consumo de matéria seca e nutrientes (Tabela 8 ), onde os animais que foram alimentados com a dieta controle, em média apresentaram um maior consumo de matéria 
seca e nutrientes totais, e pelo fato de as 4 dietas desse estudo serem isoenergéticas e isoproteícas, é esperado que os animais que receberam a dieta controle apresentem maior consumo de energia bruta, digestível e líquida.

Foi observada maior na energia líquida de ganho de peso vivo ( $E \square_{g}$ Mcaldia) $(P<0,05)$ nos animais alimentados com a dieta controle quando comparados aos animais que receberam as dietas contendo uréia.

Tabela 11. Balanço de energia de acordo com as dietas experimentais

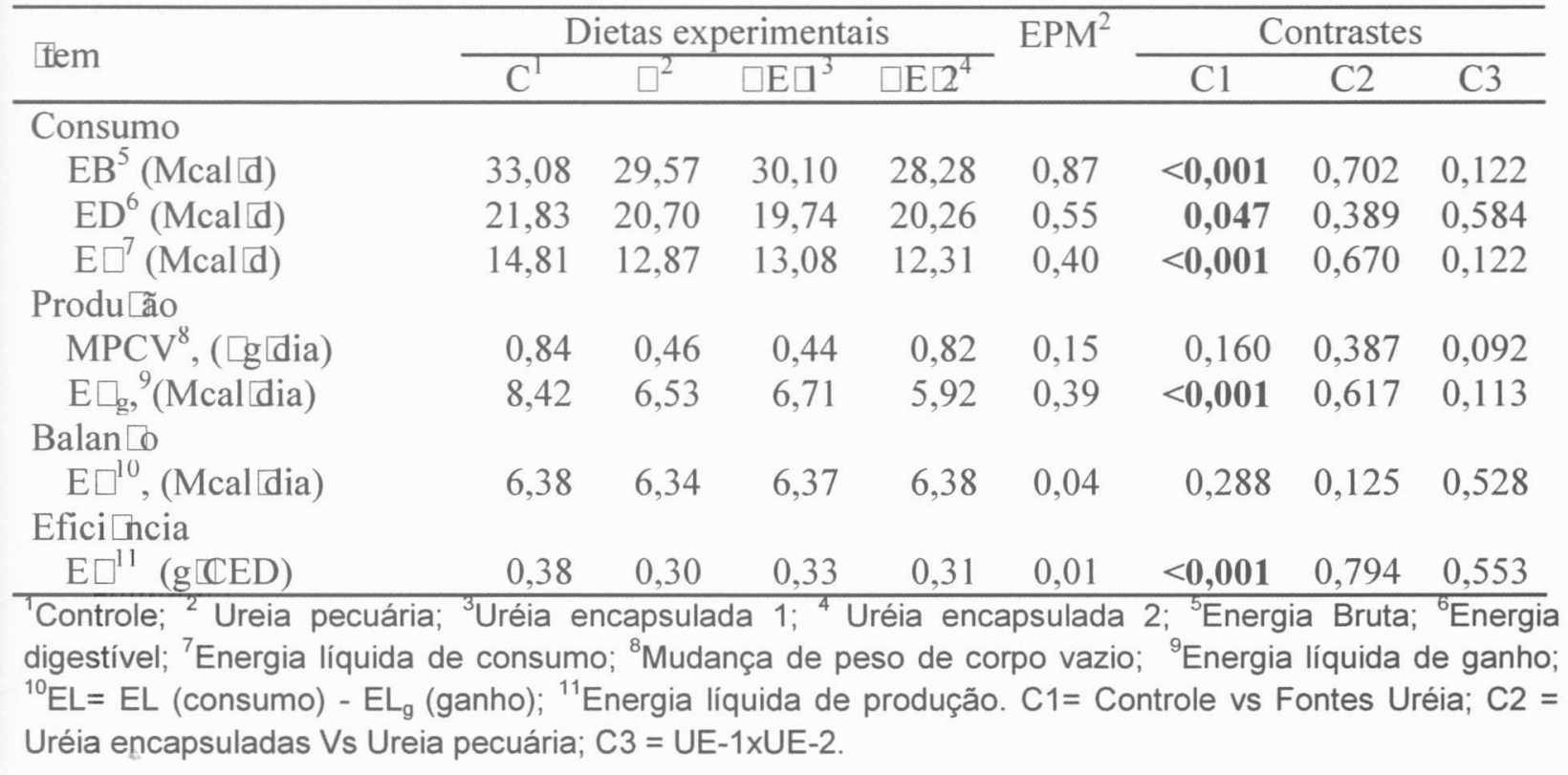

$A \mathrm{El}_{\mathrm{g}}$ de ganho de peso vivo é calculada através da diferença entre o consumo de energia líquida e a energia líquida metabolizável $\left(E L g=C E L-E L_{M}\right)$, assim como já discutido anteriormente através da Tabela 11, os animais que receberam a dieta controle apresentaram além de maior consumo de matéria seca e nutrientes, também apresentaram maior consumo de energia bruta, metabolizável e líquida, conseqüentemente era esperado que apresentassem maior energia líquida de ganho de peso vivo, pois são parâmetros dependentes um do outro. Também foi observada maior eficiência de energia líquida de produção ( $E L$ ganho/CED) $(P<0,05)$ nos animais alimentados com a dieta controle quando comparados aos animais que receberam as dietas contendo uréia. A eficiência é calculada através da divisão da energia liquida de ganho de peso vivo pelo consumo de energia digestível (EL ganho de PV/CED). 
Como observado acima a energia de ganho de peso vivo foi maior em média nos animais que foram alimentados com a dieta controle, logo é esperado que apresentem maior eficiência de energia liquida de produção.

Não foi observada a diferença na eficiência de energia líquida de produção (EL ganho/CED) $(P<0,05)$ entre os animais que foram alimentados com a dieta contendo a uréia encapsulada 1 em relação aos alimentados com a dieta contendo a uréia encapsulado do tipo 2 .

Não foi observada a diferença na mudança de peso de corpo vazio e no balanço de energia líquida $(P>0,05)$ nos animais alimentados com a dieta controle quando comparados aos animais que receberam as dietas contendo uréia.

Não foram observadas diferenças no consumo (Mcal/d) de EB, ED e EL, nem na mudança de peso de corpo vazio $(\mathrm{kg} / \mathrm{dia})$, energia líquida de ganho de peso vivo, balanço de energia líquida e eficiência $(g / C D E)(P>0,05)$ nos animais que receberam a dieta com uréia pecuária quando comparados aos animais que foram alimentados com os dois tipos de uréia encapsulada e também nem entre os animais alimentados com as uréias encapsuladas.

\subsubsection{Balanço de nitrogênio}

Foi observado maior consumo de nitrogênio ( $g$ de $N /$ dia) $(P<0,05)$ nos animais alimentados com a dieta controle quando comparados aos animais que receberam as dietas contendo uréia. Esse maior consumo está correlacionado ao maior consumo, em média, de matéria seca e nutrientes pelos animais alimentados com a dieta controle quando comparados aos animais alimentados com dietas contendo uréia (Tabela 12).

Foi observada maior quantidade de nitrogênio nas fezes e maior porcentagem de nitrogênio total nas fezes $(P<0,05)$ nos animais alimentados com a dieta controle quando comparados aos animais que receberam as dietas contendo uréia. Provavelmente essa menor quantidade de nitrogênio nas fezes dos animais que receberam dietas contendo uréia esteja correlacionada ao menor consumo de matéria seca e nutrientes. Esse resultado contradiz ao de 
Oliveira Jr (2004), que observou um menor consumo nos animais alimentados com a dieta contendo farelo de soja como fonte de proteína, mas não observou efeito de nitrogênio nas fezes.

Segundo Broderick e Reynal (2009), ao testarem o efeito de diferentes fontes de PDR na alimentação de vacas holandesas em lactação, fixaram o nível de proteína bruta nas 4 dietas experimentais em 16\% (dietas isoproteícas) e a PDR em 10,5\%, onde o nível de inclusão de uréia nas dietas foi de, 0; 0,41; 0,$84 ; 1,31 \%$, e observaram resposta linear negativa conforme aumentava a inclusão da uréia em relação ao consumo de matéria seca e consumo de nitrogênio, ainda, observaram menor produção total de fezes conforme diminuiu o consumo de matéria seca, conseqüentemente diminuição da quantidade de nitrogênio nas fezes.

Tabela 12. Balanço de nitrogênio em função das dietas experimentais.

\begin{tabular}{|c|c|c|c|c|c|c|c|c|}
\hline \multirow{2}{*}{ tem } & \multicolumn{4}{|c|}{ Dietas experimentais } & \multirow{2}{*}{ EPM } & \multicolumn{3}{|c|}{ Contrastes } \\
\hline & $\mathrm{C}^{1}$ & $\square^{2}$ & $\square \mathrm{E} \square^{3}$ & $\square \mathrm{E}\left[2^{4}\right.$ & & $\mathrm{C} 1$ & $\mathrm{C} 2$ & $\mathrm{C} 3$ \\
\hline \multicolumn{9}{|l|}{ g de Ndia } \\
\hline Consumo & 211,94 & 194,49 & 197,43 & 179,52 & 6,00 & 0,005 & 0,414 & 0,044 \\
\hline Fe[es & 77,10 & 51,23 & 65,44 & 48,38 & 3,66 & $<0,001$ & 0,176 & 0,001 \\
\hline Urina & 64,42 & 73,53 & 63,27 & 55,03 & 3,00 & 0,930 & 0,022 & 0,230 \\
\hline Balanço & 70,40 & 69,72 & 68,71 & 76,10 & 4,47 & 0,898 & 0,773 & 0,492 \\
\hline \multicolumn{9}{|l|}{$\% \mathrm{~N}$ total } \\
\hline Fezes & 35,85 & 26,50 & 32,50 & 26,16 & 1,24 & $<0,001$ & 0,117 & 0,005 \\
\hline Urina & 30,71 & 38,99 & 32,73 & 31,58 & 1,60 & 0,222 & 0,042 & 0,755 \\
\hline Balanço & 33,43 & 34,50 & 34,76 & 42,25 & 1,88 & 0,256 & 0,250 & 0,068 \\
\hline
\end{tabular}

${ }^{1}$ Controle; ${ }^{2}$ Ureia pecuária; ${ }^{3}$ Uréia encapsulada $1 ;{ }^{4}$ Uréia encapsulada $2 ;.$ C1 $=$ Controle vs Fontes de Uréia; C2 = Uréia encapsuladas Vs Ureia pecuária; C3 = UE-1XUE-2.

Foi observado maior quantidade de nitrogênio na urina (g de N/ dia) e maior porcentagem de nitrogênio total na urina $(P<0,05)$ nos animais que receberam a dieta com uréia pecuária quando comparados aos animais que foram alimentados com os dois tipos de uréia encapsulada. Este resultado provavelmente está correlacionado com a taxa de hidrolise ruminal dos diferentes tipos de uréia (uréia pecuária e uréia encapsulada) e sua concentração a nível ruminal, junto com a eficiência dos microrganismos ruminais no aproveitamento e sincronia da captação da amônia na síntese microbiana. 
Segundo Bloomfild et al. (1960), o pico de amônia ruminal em animais alimentados com uréia comum ocorre em até 2 horas após alimentação e a taxa de hidrólise da uréia ocorre quatro vezes mais rápida do que a utilização da amônia pelos microrganismos, em decorrência disso a amônia absorvida no trato gastrointestinal (nos ruminantes, principalmente no rúmen - retículo) vai para a circulação sanguínea através da veia porta e no fígado através do ciclo da uréia e é convertida em uréia, parte dessa uréia é excretada através da urina e parte volta ao rúmen através da circulação sanguínea (Visek, 1992). Segundo Taylor-Edwards et al. (2009), em estudo observaram que a uréia pecuária sofreu hidrolise rápida no rúmen gerando concentrações de $\mathrm{N}-\mathrm{NH}_{3}$ ruminal $263 \%$ maiores quando comparada a uréia de liberação lenta e que as concentrações de amônia subiram de forma acentuada após 0,5h da alimentação.

Devido a rápida hidrolise da uréia pecuária no rúmen quando comparada a uréia de liberação lenta, os microrganismos conseguem maximizar sua eficiência de síntese microbiana sincronizando melhor a disponibilidade de energia fermentável e o nitrogênio amoniacal formado da hidrólise, fazendo com que a quantidade de amônia absorvida para a circulação sanguínea, e conseqüentemente convertida em uréia no fígado, e excretada através da urina, diminua (Xin et al., 2010; Russell et al., 1992). Este fato provavelmente esteja ocorrendo no presente estudo, onde a uréia encapsulada deve estar tendo melhor modulação da sua liberação e hidrólise quando comparada a uréia pecuária.

Foi observado maior consumo de nitrogênio ( $g$ de $N /$ dia) $(P<0,05)$ nos animais que foram alimentados com a dieta contendo a uréia encapsulada 1 em relação aos alimentados com a dieta contendo a uréia encapsulado 2 . Esse maior consumo está correlacionado ao maior consumo de PB (Tabela 8) pelos animais alimentados com a dieta contendo a uréia encapsulada $1 \mathrm{em}$ relação aos alimentados com a dieta contendo a uréia encapsulado 2.

Ainda, foi observada maior quantidade de nitrogênio nas fezes ( $\mathrm{g}$ de $\mathrm{N} /$ dia) e maior porcentagem de nitrogênio total nas fezes $(\mathrm{P}<0,05)$ nos animais que foram alimentados com a dieta contendo a uréia encapsulada 1 em relação aos alimentados com a dieta contendo a uréia encapsulado 2. Essa 
menor quantidade de nitrogênio nas fezes dos animais alimentados com a dieta contendo a uréia encapsulado 2 é resultado esperado, pois estes animais que receberam a dieta contendo uréia encapsulada 2 apresentaram menor consumo de PB $(P<0,05)$ (Tabela 8).

\subsubsection{Parâmetros sanguíneos}

Foi observada maior concentração de colesterol total sanguíneo $(\mathrm{mg} / \mathrm{dl})$ $(\mathrm{P}<0,05)$ nos animais alimentados com a dieta controle quando comparados aos animais que receberam as dietas contendo uréia (Tabela 13). Segundo a tabela de proporção dos ingredientes e composição bromatológica da ração experimental expressos na matéria seca (Tabela 4) desse estudo, as dietas apesarem de serem isoproteícas e isoenergéticas, a dieta controle apresenta na sua composição maior concentração de extrato etéreo quando comparada com as dietas que contém uréia (3,62 e 2,81 \% MS da dieta, respectivamente).

O extrato etéreo é representado por lipídios, os lipídios são intensamente metabolizados no rúmen e isso tem grande correlação com o perfil de ácidos graxos disponíveis para absorção e utilização dos tecidos. Durante o metabolismo dos lipídios, ocorrem no rúmen dois importantes processos; a hidrólise das ligações éster dos lipídios e a biohidrogenação dos ácidos graxos insaturados. A absorção de ácidos graxos ocorre predominantemente no jejuno do intestino delgado, ocorrendo com menor intensidade no duodeno e no íleo. No intestino delgado os ácidos graxos ficam sob ação dos sais biliares e do suco pancreático formando micelas sendo, então, absorvidos para dentro das células intestinais (Kozloski, 2009). Dentro das células intestinais, os ácidos graxos são reesterificados em triglicerídeos, fosfolipídios e ésteres de colesterol para serem transportados inicialmente para o sistema linfático e depois para a circulação sanguínea (Bauman e Lock, 2006), assim a concentração de extrato etéreo da ração está diretamente correlacionado com a quantidade de colesterol formado e que será absorvida posteriormente para a circulação. Portanto, este maior aumento na 
concentração de colesterol sérico nos animais alimentados com a dieta controle é esperada e condiz com a literatura.

Tabela 13. Parâmetros sanguíneos de acordo com as fontes de uréia utilizadas nas dietas experimentais

\begin{tabular}{|c|c|c|c|c|c|c|c|c|}
\hline \multirow{2}{*}{$\square$ ari $\square$ Tel } & \multicolumn{4}{|c|}{$\square$ ietas e $\square$ eri $\square$ entais } & \multirow{2}{*}{$\square \square \square$} & \multicolumn{3}{|c|}{$\square$ ontrates } \\
\hline & $\square^{1}$ & $\mathrm{U}^{2}$ & $\mathrm{U} \square \square^{3}$ & $\mathrm{U} \square 2^{4}$ & & $\square 1$ & $\square 2$ & $\square 3$ \\
\hline \multicolumn{9}{|c|}{ पवा1] } \\
\hline$\square$ li $\square$ ose $\square \square \square \square$ & 79,87 & 84,37 & 83,50 & 84,25 & 1,65 & 0,078 & 0,835 & 0,787 \\
\hline$\square$ olesterol total $\square \square \square \square$ & 199,50 & 191,38 & 192,38 & 181,50 & 3,67 & 0,024 & 0,367 & 0,065 \\
\hline$\square$ rote nas totais $\square \square \square \square$ & 6,01 & 5,77 & 6,12 & 6,10 & 0,09 & 0,952 & 0,140 & 0,922 \\
\hline$\square 1 \square$ ina $\square \square \square$ & 2,69 & 2,66 & 2,72 & 2,67 & 0,02 & 0,981 & 0,366 & 0,267 \\
\hline Ur & 38,87 & 25,25 & 35,12 & 43,75 & 1,94 & 0,245 & 0,001 & 0,057 \\
\hline 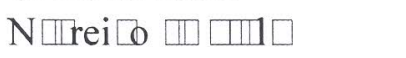 & 18,18 & 11,78 & 16,43 & 20,43 & 0,90 & 0,240 & 0,001 & 0,059 \\
\hline$\square$ reatinina $\square \square \| 10$ & 2,20 & 2,15 & 1,98 & 2,30 & 0,09 & 0,756 & 0,973 & 0,154 \\
\hline \multicolumn{9}{|l|}{ 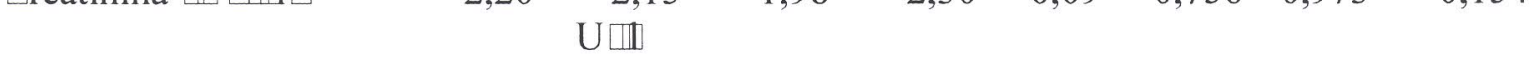 } \\
\hline 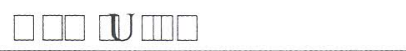 & 34,62 & 52,00 & 45,75 & 32,12 & 3,76 & 0,317 & 0,156 & 0,198 \\
\hline
\end{tabular}

${ }^{1}$ Controle; ${ }^{2}$ Ureia pecuária; ${ }^{3}$ Uréia encapsulada $1 ;{ }^{4}$ Uréia encapsulada $2 ;.$ C $1=$ Controle vs Fontes de Uréia; C2 = Uréia encapsuladas Vs Ureia pecuária; C3 = UE-1xUE-2.

Não foram observadas diferenças nas concentrações $(\mathrm{mg} / \mathrm{dl})$ de nitrogênio ureico e uréia plasmática no soro $(P>0,05)$ nos animais alimentados com a dieta controle quando comparados aos animais que receberam as dietas contendo uréia. Discordando dos resultados obtidos no presente estudo, Oliveira et al. (2001), ao submeterem vacas leiteiras a dietas com níveis crescentes de uréia $(0 ; 0,7 ; 1,4$ e $2,1 \%$ na base da MS), reportaram aumento linear nos valores de nitrogênio ureico plasmática em função dos tratamentos, atribuindo esses resultados à redução na eficiência de utilização de amônia no rúmen pelos microrganimos. Ainda, Rennó et al. (2003) observaram aumento linear na concentração de nitrogenio ureico e uréia plasmática em função dos níveis de uréia $(0 ; 0,65 ; 1,30$ e $1,95 \%$ na $M S)$ na dieta de novilhos.

Da mesma forma, Cecava e Hancock (1994) verificaram que a excreção de nitrogênio urinário e as concentrações de nitrogênio ureico plasmático foram maiores em novilhos alimentados com dietas contendo uréia (1,35\% na MS) do que naqueles que receberam combinações de farelo de soja e farinha de penas na dieta. 
No entanto, Moraes (2003) não verificou efeito de níveis crescentes de uréia em suplementos para novilhos em pastejo, sobre as concentrações de nitrogênio ureico plasmática, fato este também encontrado por Magalhães (2003) na dieta de novilhos. Segundo Broderick (1995), citado por Valadares et al. (1997), a concentração elevada de uréia plasmática está relacionada com a utilização ineficiente da proteína bruta da dieta. Segundo, Harmeyer e Martens (1980), a concentração de N-uréico e uréia plasmático, que é sintetizada no fígado, é proporcional à quantidade de amônia produzida no rúmen, fato este observado neste estudo, pois ao observar a tabela de fermentação ruminal (Tabela 9), animais alimentados com a dieta controle quando comparados aos animais que receberam as dietas contendo uréia não apresentaram diferença $(P<0,05)$ para concentrações de nitrogênio amoniacal.

Foram observados menores valores para concentração $(\mathrm{mg} / \mathrm{dl})$ de uréia e nitrogênio ureico no soro $(P<0,05)$ nos animais que receberam a dieta com uréia pecuária quando comparados aos animais que foram alimentados com os dois tipos de uréia encapsulada. Este resultado contradiz aos observados por Knaous et al. (2001) em novilhos em crescimento. Segundo Huntington e Archibeque (1999), a concentração de uréia plasmática está relacionada com taxa de produção de $\mathrm{N}-\mathrm{NH}_{3}$ no rúmen que é reflexo da solubilidade e da fermentabilidade da dieta, bem como a produção endógena de compostos nitrogenados.

Em virtude do fato de a hidrólise da uréia ser mais rápida que a capacidade de assimilação de amônia pelos microrganismos ruminais (Coelho da Silva e Leão, 1979), espera-se que a concentração de $\mathrm{N}^{-\mathrm{NH}_{3}}$ ruminal aumente em função da maior concentração de amônia liberada, estudos mostram (Xin et al., 2010 e Taylor-Edwards et al., 2009) que uréia encapsulada tem uma liberação e conseqüentemente hidrolise mais modulada quando compara a uréia pecuária.

Assim o resultado encontrado neste estudo de concentração de uréia e nitrogênio ureico no soro nos animais que receberam a dieta com uréia pecuária quando comparados aos animais que foram alimentados com os dois tipos de uréia encapsulada, contradizem aos resultados esperados. Pois ao observar os resultados da tabela de fermentação ruminal (Tabela 9), animais 
que foram alimentados com dietas contendo uréia comum apresentaram, em média, valor superior de concentração de nitrogênio amoniacal $(P<0,05)$ em relação a animais alimentados com dietas contendo as uréias encapsuladas. Assim era esperado que animais que foram alimentados com dietas contendo uréia encapsulada apresentassem menores concentrações de uréia e nitrogênio ureico no soro.

Não foram observadas diferenças nas concentrações de glicose sérica, proteínas totais, albumina ( $\mathrm{mg} / \mathrm{dl})$ e AST (Ul/l) $(\mathrm{P}>0,05)$ quando comparou os animais que receberam a dieta controle quando comparados aos animais que receberam dietas contendo uréia, nem entre os animais que receberam a dieta com uréia pecuária quando comparados aos os animais que foram alimentados com os dois tipos de uréia encapsulada e nem entre os animais que foram alimentados com a dieta contendo a uréia encapsulada 1 em relação aos alimentados com a dieta contendo a uréia encapsulado 2 .

Não foi observada diferença na concentração de colesterol total sérico ( $\mathrm{mg} / \mathrm{dl})(P>0,05)$ entre os animais que receberam a dieta com uréia pecuária quando comparados aos os animais que foram alimentados com os dois tipos de uréia encapsulada. Ainda, não foram observadas diferenças nas concentrações de colesterol total, nitrogênio ureico e uréia séricos $(\mathrm{mg} / \mathrm{dl})$ $(P>0,05)$ entre os animais que foram alimentados com a dieta contendo a uréia encapsulada 1 em relação aos alimentados com a dieta contendo a uréia encapsulado 2.

\subsection{Conclusões}

A utilização de uréia encapsulada de liberação lenta em rações de novilhos canulados reduziu a concentração de $\mathrm{N}-\mathrm{NH}_{3}$ ruminal e melhorou a digestibilidade de proteína bruta

Níveis de inclusão de $2 \%$ de uréia em relação a matéria seca da dieta diminuiram o consumo de matéria seca dos animais. 


\subsection{Experimento 2}

\subsubsection{Desempenho animal e Qualidade de carcaça}

Foram observados maiores peso final $(\mathrm{kg})$ e ganho de peso $(\mathrm{kg} / \mathrm{dia})$ $(\mathrm{P}<0,05)$ nos animais alimentados com a dieta controle quando comparados aos animais que receberam as dietas contendo uréia (Tabela 14). Resultados semelhantes foram observados por Paixão (2006) ao substituir a proteína da soja pelo NNP da uréia (0 e 100\%) com dois níveis de inclusão de concentrado $(0,75$ e $1,25 \%$ do PV) na dieta de 16 novilhos. Também Obeid et al. (1980) ao substituírem a proteína da soja por NNP (0, 50 e 100\%) na dieta de 72 novilhos observaram que a inclusão de $100 \%$ de uréia, comprometeu o ganho de peso dos animais.

Entretanto, Seixas et al. (1999) utilizando rações com diferente fonte proteícas (farelo de soja, uréia e amiréia) na dieta de 30 bovinos cruzados, não observaram diferença estatística no ganho de peso dos animais e peso final, o mesmo comportamento foi observado por Magalhães (2003). Os estudos citados a cima não observaram diferença no consumo dos animais $(P>0,05)$, aspecto que provavelmente não esteja ocorrendo neste estudo, pois ao observar as médias de consumo dos diferentes lotes, observa-se que animais que foram alimentados com a dieta controle em média apresentaram maior consumo em relação aos que foram alimentados com dietas contendo uréia. 
Tabela 14. Desempenho e qualidade da carcaça de novilhos Nelore em confinamento em função das dietas experimentais.

\begin{tabular}{|c|c|c|c|c|c|c|c|c|c|c|c|c|c|c|}
\hline \multirow{2}{*}{ ari el } & \multicolumn{7}{|c|}{ lietas e eri entais } & \multirow{2}{*}{$|\|\||$} & \multicolumn{6}{|c|}{ ontrastes $^{8}$} \\
\hline & 11 & $U 11^{2}$ & $\mathrm{U} / 2^{3}$ & $\mathrm{U}: 111^{4}$ & $\mathrm{U} \mid 112^{5}$ & $\mathrm{U} 2: 1^{6}$ & $\mathrm{U}|2| 2^{7}$ & & 41 & 2 & 13 & 14 & 5 & $\square 6$ \\
\hline \multicolumn{15}{|l|}{ Desempenho } \\
\hline ons $/$ o $\| /$ ia $\mathrm{i}$ rio \|\|\|\| $\mathrm{ia}$ & 11,15 & 9,67 & 8,34 & 9,49 & 9,20 & 9,61 & 9,54 & & & & & & & \\
\hline eso ini ial & 352,1 & 348,6 & 344,6 & 353,2 & 352,5 & 356,4 & 353,3 & 3,42 & {$[.11]$} & {$[11$} & [II! & {$[111$} & [II] & $\square$ \\
\hline eso inal $\| H$ & 490,0 & 485,1 & 462,9 & 486,5 & 454,3 & 464,3 & 466,0 & 4,79 & 0,004 & 0,270 & 0,125 & $<0,001$ & 0,001 & 0,419 \\
\hline an o e eso ia & 1,65 & 1,57 & 1,33 & 1,59 & 1,25 & 1,38 & 1,40 & 0,03 & 0,005 & 0,492 & 0,120 & $<0,001$ & 0,004 & 0,645 \\
\hline \multicolumn{15}{|l|}{ Caracteristicas de carcaça } \\
\hline rea $\mid$ e ol o e lo $\|$ o $\|\left._{1}\right|^{2} \mid$ & 67,72 & 68,19 & 66,78 & 68,26 & 65,36 & 68,43 & 71,66 & 0,88 & 0,870 & 0,638 & 0,827 & 0,934 & 0,850 & 0,179 \\
\hline $\mathrm{s}$ ess ra $\mathrm{e}$ or $\mid$ ra $\mathrm{s} \| \mathrm{t}$ nea \|\|$\|$ & 2,92 & 3,19 & 3,09 & 3,63 & 3,00 & 3,36 & 3,09 & 0,13 & 0,425 & 0,688 & 0,261 & 0,723 & 0,285 & 0,814 \\
\hline
\end{tabular}


Foram observados maiores peso final $(\mathrm{kg})$ e ganho de peso $(\mathrm{kg} / \mathrm{dia})$ $(\mathrm{P}<0,05)$ nos animais alimentados com a dieta controle quando comparados aos animais que receberam as dietas contendo inclusão de $2 \%$ de uréia em relação a matéria seca da dieta. Ainda, foram observados maior peso final $(\mathrm{kg})$ e ganho de peso $(\mathrm{kg} / \mathrm{dia}) \quad(\mathrm{P}<0,05)$ nos animais alimentados com dietas contendo inclusão de $1 \%$ de uréia quando comparados aos animais que receberam as dietas contendo inclusão de $2 \%$ de uréia na matéria seca da dieta.

Não foram encontradas diferenças no peso final $(\mathrm{kg})$ e ganho de peso ( $\mathrm{kg} / \mathrm{dia})$ entre os animais que foram alimentados com a dieta controle em relação aos animais que foram alimentados com dietas contendo $1 \%$ de uréia. Ao serem observados os valores médios de consumo dos diferentes tratamentos, pode-se observar que os animais que foram alimentados com dietas contendo $2 \%$ de inclusão de uréia na matéria seca total da dieta apresentaram menor consumo quando comparados aos animais que receberam a dieta controle ou mesmo aos animais que receberam dietas contendo $1 \%$ de inclusão de uréia. Portanto, provavelmente a inclusão de $2 \%$ de uréia na dieta, neste caso, deve estar levando a uma diminuição de consumo.

Segundo Haddad (1984) e Salman et al.,1996, níveis elevados de uréia na dieta podem provocar redução no consumo de matéria seca, em virtude de sua palatabilidade, fato que foi comprovado por Silva et al. (1997) e Feijó et al. (1997) ao avaliarem dietas para terminação de novilhos Nelore e F1 Pardo Suíço $\mathrm{x}$ Nelore, respectivamente, nas quais o farelo de soja foi substituído por uréia $(0,50$ e 100\%).

Da mesma forma, Paixão (2006) substituindo a proteína da soja pelo NNP da uréia (0 e 100\%) em dois níveis de inclusão de concentrado $(0,75$ e $1,25 \%$ do PV) na dieta de novilhos com dois níveis de concentrado observou diminuição no consumo de animais alimentados com maior porcentagem de uréia na dieta, Wilson et al. (1975) ao fornecerem níveis crescentes de uréia $(1,0 ; 1,65 ; 2,30$ e 3,0\% na MS total) para novilhos, seja via oral ou por infusão direta no rúmen, verificaram que a uréia parece deprimir o consumo quando é incluída na dieta em níveis acima de 2,0\%, Fernandes et al. (2004) avaliaram a 
influência do aumento da proteína metabolizável, por meio da inclusão de farelo de soja em substituição à uréia, no desempenho de 24 animais Nelores e 13 Canchim e verificaram menor ganho de peso diário naqueles que receberam maior proporção de uréia na dieta (2, 1 e $0 \%$ de uréia na MS total das rações).

Já Milton et al. (1997), em um trabalho conduzido com novilhos na fase de terminação que foram submetidos a dietas com níveis crescentes de uréia ( $0 ; 0,35 ; 0,7 ; 1,05$ ou $1,4 \%$ na MS), observaram efeito quadrático sobre 0 consumo de MS, que apresentou o maior valor com a inclusão de 1,05\% de uréia na dieta dos animais. Portanto o fato de os animais alimentados com dietas com $2 \%$ de inclusão de uréia apresentarem menor peso final e menor ganho de peso deve-se ao fato de apresentarem menores consumos em relação as outras dietas, fato este verificado no experimento 1.

Não foram observadas diferenças no peso final $(\mathrm{kg})$ e ganho de peso ( $\mathrm{kg} / \mathrm{dia})(\mathrm{P}<0,05)$ entre os animais que foram alimentados com a dieta contendo uréia pecuária em relação aos animais que foram alimentados com dietas contendo uréia encapsulada. Ainda, não foi observado diferença no desempenho entre os animais que foram alimentados com a dieta contendo uréia encapsula 1 em relação aos animais que foram alimentados com dietas contendo uréia encapsulada 2.

Analisando as características de carcaça, não foram encontradas diferenças na área de lombo $\left(\mathrm{cm}^{2}\right)$ e espessura de gordura subcutânea $(\mathrm{mm})$ $(P>0,05)$ nos animais que receberam dieta controle quando comparados aos animais que receberam dietas contendo uréia, nem entre as demais dietas experimentais.

O grau de acabamento das carcaças é avaliado pela espessura de gordura subcutânea (EGS), sendo esta a característica de maior impacto no rendimento, visto que o rendimento de carne magra diminui com o aumento na EGS. Luchiari Filho (2000) considera que uma carcaça de boa qualidade deve apresentar EGS de no mínimo $3,0 \mathrm{~mm}$. No presente estudo os valores encontrados para EGS nos animais dos diferentes lotes, em média, estão próximos de 3,0 $\mathrm{mm}$.

Hussein e Berger (1995), em experimento com novilhos holandeses, não verificaram comprometimento das características de carcaça dos animais, 
quando $50 \%$ da proteína do farelo de soja foi substituída pela uréia. Shain et al. (1998), trabalhando com animais em confinamento recebendo níveis crescentes de uréia na ração (0; 0,88; 1,34 e 1,96\% na MS), não encontraram diferenças no peso de carcaça quente e na EGS nos animais dos diferentes tratamentos. Resultados semelhantes foram encontrados por Milton et al. (1997) usando níveis crescentes de uréia (0; 0,5; 1,0 e 1,5\% na MS) na ração de novilhos em terminação, verificando que a área de olho de lombo não foi afetada pelos diferentes níveis, enquanto que a EGS apresentou comportamento linear crescente com a inclusão de uréia na dieta. Resultados que vão de encontro aos encontrados neste estudo.

Seria esperada uma maior EGS nos animais tratamentos com a dieta controle, em virtude do maior GPD e maior peso vivo final dos animais destes tratamentos, quando comparados aos animais suplementados com dieta contendo uréia, mas não foi o que aconteceu no presente estudo.

\subsubsection{Parâmetros sanguíneos}

Não foi encontrada diferença na concentração de glicose sérica $(\mathrm{mg} / \mathrm{dl})$ $(P>0,05)$ nos animais que receberam dieta controle quando comparados aos animais que receberam dietas contendo uréia (Tabela 15). Este resultado está de acordo com outros trabalhos encontrados na literatura, onde houve comparações entre farelo de soja e uréia (Broderick et al., 1993; Guidi, 1999) e não foi observado diferença.

Foi observada menor concentração de glicose sérica $(\mathrm{mg} / \mathrm{dl}) \quad(\mathrm{P}<0,05)$ entre os animais que foram alimentados com a dieta contendo uréia pecuária em relação aos animais que foram alimentados com dietas contendo uréia encapsulada. Segundo Huntington (1997), à existência de aumento de glicose sérica está, em parte, correlacionado com o aumento da concentração molar de propionato ruminal, pois o propionato é o principal substrato para a síntese de glicose no fígado (gliconeogênese) em ruminates. Neste experimento não foi mensurado a fermentação ruminal nos animais dos diferentes tratamentos, mas se mantermos uma correlação com o experimento 1 deste estudo, parte 
dessa diminuição de glicose pode ser explicada observando os dados de fermentação ruminal (Tabela 9), onde animais que receberam dietas contendo uréia pecuária quando comparados com os animais que foram alimentados com dietas contendo uréia encapsulada (Tabela 10) apresentaram menor concentração de propionato ruminal (mol/l), condizentes aos achados de Huntington (1997).

Não foi encontrada diferença na concentração de glicose sérica $(\mathrm{mg} / \mathrm{dl})$ $(P>0,05)$ nos animais que foram alimentados com a dieta controle em relação aos animais que foram alimentados com dietas contendo $1 \%$ de uréia e nem entre os animais que foram alimentados com a dieta controle quando comparados aos animais que receberam as dietas contendo inclusão de $2 \%$ de uréia. 
Tabela 15. Parâmetros sanguíneos de novilhos Nelore em confinamento em função das dietas experimentais.

\begin{tabular}{|c|c|c|c|c|c|c|c|c|c|c|c|c|c|c|}
\hline \multirow{2}{*}{ ari el } & \multicolumn{7}{|c|}{ lietas e eri entais } & \multirow{2}{*}{1\|\| 1} & \multicolumn{6}{|c|}{ lontrates ${ }^{8}$} \\
\hline & 1 & $\mathrm{U} 11^{2}$ & $\mathrm{U} / 2^{3}$ & $\mathrm{U} \mid 11^{4}$ & $\mathrm{U} / 112^{5}$ & $\mathrm{U}|2| 1^{6}$ & $\mathrm{U}|2| 2^{7}$ & & $\mid ! 1$ & 112 & 13 & {$[14$} & 15 & 6 \\
\hline li ose 11 & 111,4 & 109,8 & 99,4 & 133,1 & 121,8 & 118,6 & 138,1 & 6,71 & 0,271 & $<0,001$ & 0,260 & 0,357 & 0,779 & 0,838 \\
\hline rote nas totais, $\quad 11$ & 5,57 & 5,43 & 6,12 & 5,42 & 6,11 & 6,66 & 7,54 & 0,23 & $<0,001$ & $<0,001$ & 0,131 & $<0,001$ & $<0,001$ & $<0,001$ \\
\hline 11 ina 1 & 2,33 & 2,18 & 2,61 & 2,11 & 2,84 & 2,66 & 2,70 & 0,07 & $<0,001$ & $<0,001$ & 0,754 & $<0,001$ & $<0,001$ & $<0,001$ \\
\hline olesterol total 1 & 180,2 & 193,1 & 172,6 & 167,6 & 173,7 & 186,3 & 192,2 & 5,79 & 0,928 & 0,693 & 0,812 & 0,945 & 0,674 & 0,013 \\
\hline$: \| 1 \mid$ U 1 & 78,0 & 86,1 & 87,8 & 69,8 & 73,5 & 70,0 & 74,1 & 3,17 & 0,781 & $<0,001$ & 0,464 & 0,832 & 0,201 & 0,919 \\
\hline Ur ia $\|11\| 1$ & 33,0 & 32,2 & 35,4 & 29,6 & 31,1 & 30,3 & 35,2 & 1,55 & 0,590 & 0,074 & 0,113 & 0,555 & 0,004 & 0,057 \\
\hline NU & 15,4 & 15,1 & 16,5 & 13,8 & 14,5 & 14,2 & 16,4 & 0,72 & 0,590 & 0,073 & 0,114 & 0,556 & 0,003 & 0,056 \\
\hline reatinina, |||| $1 \mid$ & 1,91 & 1,83 & 1,89 & 1,94 & 1,99 & 1,81 & 1,92 & 0,05 & 0,826 & 0,354 & 0,482 & 0,769 & 0,176 & 0,092 \\
\hline
\end{tabular}


Foi observada maior concentração de AST (UI/dl) $(P<0,05)$ entre os animais que foram alimentados com a dieta contendo uréia pecuária em relação aos animais que foram alimentados com dietas contendo uréia encapsulada. Roller et al. (1982) trabalhando com intoxicação por amônia em ovinos, encontraram altas atividades de AST em animais que apresentavam concentrações elevadas de amônia ruminal e sérica, atribuindo esta elevação a possíveis lesões hepáticas devido a metabolização desta no fígado. Neste estudo, provavelmente os animais que estão sendo alimentados com dietas contendo uréia pecuária estão apresentando maior hidrolise ruminal da uréia quando comparados com aqueles que então recebendo dieta contendo uréia encapsulada, indicando que provavelmente a liberação de nitrogênio ruminal destas esteja ocorrendo mais lentamente devido ao encapsulamento da uréia.

Não foi encontrada diferença na concentração de AST (Ul/dl) $(\mathrm{mg} / \mathrm{dl})$ $(P>0,05)$ entre os animais que foram alimentados com a dieta controle em relação aos animais que foram alimentados com dietas contendo $1 \%$ de uréia, o que ocorreu também entre os animais que foram alimentados com a dieta controle quando comparados aos animais que receberam as dietas contendo inclusão de $2 \%$. Segundo Huntington e Archibeque (1999), a taxa de produção de $\mathrm{N}-\mathrm{NH}_{3}$ no rúmen reflete a solubilidade e a fermentabilidade da dieta, bem como a produção endógena de compostos nitrogenados. Diante disso, TaylorEdwards et al. (2009) observaram que a uréia comum sofre hidrolise rápida no rúmen gerando concentrações de $\mathrm{N}-\mathrm{NH}_{3}$ ruminal $263 \%$ maiores quando comparada a uréia de liberação lenta. Provavelmente, neste estudo, os animais tratados com dietas contendo uréia encapsulada, pelo fato de apresentarem valores de concentração de AST (UI/dl) próximos aos animais alimentados com a dieta controle (sem inclusão de uréia), estejam tendo uma satisfatória sincronia de liberação de uréia.

Foram observadas menores concentrações de uréia e nitrogênio ureico no soro $(\mathrm{mg} / \mathrm{dl}) \quad(P<0,05)$ nos animais que foram alimentados com dietas contendo inclusão de $1 \%$ de uréia quando comparados aos animais que receberam as dietas contendo inclusão de $2 \%$ de uréia. Segundo, Harmeyer e Martens (1980), a concentração de N-ureico e uréia plasmático, que é sintetizada no fígado, é proporcional à quantidade de amônia produzida no 
rúmen, e uma compilação de resultados mostrou que conforme há um aumento na inclusão de uréia na dieta há um aumento da formação de nitrogênio amoniacal ruminal (Oliveira et al., 2001; Rennó, 2003; Cecava e Hancock, 1994; Galina et al., 2003; Golombeski et al., 2006). Devido a alta capacidade da amônia, ser altamente absorvida pelos epitélios ruminal e abomasal ela passa para a circulação sanguínea e é metabolizada pelo fígado e convertida em uréia pelo ciclo da uréia. Portanto o aumento das concentrações do nitrogênio ureico e uréia sérica são reflexos de maiores concentrações de uréia na dieta, fato este observado nas dietas com inclusão de $2 \%$ de uréia quando comparadas as com $1 \%$ de inclusão de uréia.

Foram observada menores concentrações proteínas totais e albumina (mg/dl) $\quad(P<0,05)$ nos animais que receberam dieta controle quando comparados aos animais que receberam dietas contendo uréia. Em adição, foram observadas menores concentrações proteínas totais e albumina $(\mathrm{mg} / \mathrm{dl})$ $(P<0,05)$ nos animais que receberam dieta contendo uréia pecuária em relação aos animais que foram alimentados com dietas contendo uréia encapsulada. Também, foram observadas menores concentrações de proteínas totais e albumina $(\mathrm{mg} / \mathrm{dl}) \quad(\mathrm{P}<0,05)$ nos animais que receberam dieta controle em relação aos animais que foram alimentados com dietas contendo $1 \%$ de uréia em relação a matéria seca da dieta total e menores concentrações de proteínas totais e albumina $(\mathrm{mg} / \mathrm{dl})(\mathrm{P}<0,05)$ nos animais que receberam dieta controle quando comparados aos animais que receberam as dietas contendo inclusão de $2 \%$ de uréia.

Ainda, foram observadas menores concentrações proteínas totais e albumina $(\mathrm{mg} / \mathrm{dl})(P<0,05)$ nos animais que receberam dieta contendo uréia encapsula 1 em relação aos animais que foram alimentados com dietas contendo uréia encapsulada 2 (C6).

Os valores de proteínas totais e albumina nos diferentes tratamentos estão dentro da normalidade, onde os valores de referência segundo Morris (1993), são de 5,0 a 7,5 mg/dl de proteínas totais e de 2,0 a 3,0 mg/dl para albumina. Mas as diferenças observadas entre os tratamentos não são conclusivas e não foi encontrado nada que explicasse ou pudesse correlacionar na literatura. 


\subsection{Conclusões}

A utilização de $2 \%$ inclusão de uréia, encapsulada ou não, em relação à matéria seca total da dieta, resulta em redução de desempenho dos animais. No entanto, $1 \%$ de inclusão em relação à matéria seca não influenciou nos resultados.

$\mathrm{Na}$ condição em que este estudo foi realizado não foi observado diferença no desempenho entre animais submetidos à dieta com uréia pecuária e uréia encapsulada.

\section{Referências}

AIRES, M.M. Fisiologia básica. Rio de Janeiro: Guanabara Koogan, 1985. $564 p$.

ANUALPEC, 2010, Anuário da Agropecuária Brasileira, São Paulo: FNP Consultoria e comércio, p5.

AKAY, V.; TIKOFSKY,J.; HOLTZ, C.; DAWSON, K. 2004.Optigen 1200: controlled rease of nonprotein nitrogen in the rumen. In: NUTRITIONAL BIOTECHNOLOGY IN THE FEED AND FOOD INDUSTRIES, ALLTECH'S TWENTY FIRST ANNUAL SIMPOSIUM, 20., 2004, Nottingam. Proceedings... Nottingam: Nottingam University Press, p. 179-185.

AMIN, M. R.; R. ONODERA. 1997. Synthesis of phenylalanine and production of other related compounds from phenylpyruvic acid and phenylacetic acid by ruminal bacteria, protozoa, and their mixture in vitro. J. Gen. Appl. Microbiol. 43:9-15.

ATASOGLU, C., A. Y. GULIYE,; R. J. WALLACE. 2004. Use of stable isotopes to measure de novo synthesis and turnover of amino acid-C and $-\mathrm{N}$ in mixed micro-organisms from the sheep rumen in vitro. Br. J. Nutr. 91:235-261.

ATASOGLU, C.; VALDES, C.; NEWBOLD, C. J.,; WALLACE, R. J. 1999. Influence of peptides and amino acids on fermentation rate and de novo synthesis of amino acids by mixed micro-organisms from the sheep rumen. $\mathrm{Br}$. J. Nutr. 81:307-314. 
BACH, A; CALSAMIGLIA, S; STERN, M.D. 2005. Nitrogen metabolism in the rumen. J. Dairy Sci.; 88: 9-21.

BAUMAN, D.E.; LOCK, A.L. 2006. Concepts in Lipid Digestion and Metabolism in Dairy Cows. Tri-State Dairy Nutrition Conference.

BIGGS, H. G.; COOPER, J. M. 1961. An evaluation of four methods of measuring urinary creatinine. Clinical Chemistry, v. 7, p. 665-673.

BLAXTER, K.L.1962. The energy metabolism of ruminants. London: Hutchinson, 329p.

BLOOMFIELD, R.A.; KEARLEY, E.O.; CHERCH, D.O.; MUHRER,M.E. 1963. Ruminal $\mathrm{pH}$ and absorption of ammonia and VFA. Journal of Animal Science, Champaign, v.22, n.3, p. 833.

BRODERICK, G.A.; RAYNAL, S.M. 2009.Effect of source of rumen-degraded protein on production and ruminal metabolism in lactating dairy cows. J. Dairy Sci. 92:2822-2834.

BRODERICK, G.A. et al. 1993. Urea versus true protein as supplement for lactating dairy cows fed grain plus mixtures of alfafa and corn silages. J. Dairy Sci., Savoy, v.76, p.2266-2274.

CALSAMIGLIA, S.; FERRET A.; DEVANT, M. 2002. Effects of pH and pH fluctuations on microbial fermentation and nutrient flow from a dual-flow continuous culture system. J. Dairy Sci. 85:574-579.

CAMERON, M. R.; KLUSMEYER,T.H; LYNCH, G. L.; CLARK, J. H.; NELSON, D. R. 1991. Effects of urea and starch on rumen fermentation, nutrient passage to the duodenum, and performance of cows. J. Dairy Sci. 74:1321-1336.

CASALI, A. O. 2006. Procedimentos metodologicos in situ na avaliação do teor de compostos indigestíveis em alimentos e fezes de bovinos. 2006. $47 \mathrm{f}$. Dissertação (Mestrado em Ciências) - Universidade Federal de Viçosa, Viçosa.

CASPER, D. P.; SCHINGOETHE, D. J.. 1989. Lactational response of dairy cows to diets varying in ruminal solubilities of carbohydrate and crude protein. J. Dairy Sci. 72:928-941.

CASS, J.L.; RICHARDSON, C.R., 1994. In vitro ammonia release from urea/calcium compounds as compared to urea and cottonseed meal. Texas Tech. Univ. Agr. Sci. Natl. Res. Tech. Rpt. No. T-5-342. Texas Tech University, Lubbock, TX, USA.

CECAVA, M.J.; HANCOCK, D.L. 1994. Effects of anabolic steroids on nitrogen metabolism and growth of steers fed corn silage and corn-based diets supplemented with urea or combinations of soybean meal and feathermeal. Journal of Animal Science, v.72, p.515-522. 
CHEN, X. B.; GOMES, M. J. 1992. Estimation of microbial protein supply to sheep and cattle based on urinary excretion of purine derivatives - an overview of technical details. (Occasional publication). Bucksburnd, Aberdeen: International Feed Research Unit; Rowett Research Institute,.21 p. (Occasional Publication).

CHERDTHONG, A., M.; WANAPAT, C; WACHIRAPAKORN, M. E.; VAN AMBURGH, 2010. Evaluation of ureacalcium mixtures (UCM) as slow-release: I. Fermentation characteristics using in vitro gas technique. In: Proceedings of the Agriculture Conference 11th. January 25-26, 2010. Kawee Jutikul Auditorium, Khon Kaen University, Khon Kaen, Thailand, pp: 138-141.

CHURCH, D.C. 1979. Digestive physiology and nutrition of ruminant. Vol $1-$ Digestive Physiology . 3. ed. Oxford: Oxford Press Inc., 350p.

DE PETERS, E.J.; FERGUNSON, J.D. 1992. Nonprotein nitrogen and protein distribution in the milk of cows. J. Dairy Sci.; 75: 3192-209.

CLARINDO, R.L; SANTOS, F.A.P; BITTAR, C.M.M.; IMAIZUMI, H.; LIMA, N.V.A; E PEREIRA, E. M. 2008. Avaliação de fontes energéticas e protéicas na dieta bovinos confinados em fase de terminação. Ciência Animal Brasileira, out./dez, v. 9, n. 4, p. 902-910

CLARK, J. H.; KLUSMEYER, T. H.; CAMERON, M. R. 1992. Microbial protein synthesis and flows of nitrogen fractions to the duodenum of dairy cows. J. Dairy Sci. 75:2304-2323.

COELHO DA SILVA, J.F.; LEÃO, M.I. 1979. Fundamentos de nutrição de ruminantes. Piracicaba: Livroceres, 380p.

COUTINHO FILHO, J.L.V.; SAMPAIO, A. A M.; EZEQUIEL, J.M.B. 1995.Efeito de fontes de nitrogênio e da cobertura de cocho sobre o desempenho de bovinos confinados. Revista Sociedade Brasileira de Zootecnia, v.24, n.3, p.363 -370 .

CRURCH, D. C. 1990.The ruminant animal: digestive physiology and nutrition.Englewood Cliffs: Waveland Press, $563 \mathrm{p}$.

DEWHURST, R. J.; DAVIES, D. R.; MERRY, R. J. 2000. Microbial protein supply from the rumen. Anim. Feed Sci. Technol. 85:1-21. Dijkstra, J. 1994. Simulation of the dynamics of protozoa in the rumen. Br. J. Nutr. 72:679-699.

ERWIN, E. S.; MARCO, G. J.; EMERY, E. M. 1961. Volatile fatty acid analyses of blood and rumen fluid by gas chromatography. Journal of Dairy Science, $v$. 44, n. 9, p. 1768-1777.

FEIJÓ, G.L.D.; SILVA, J.M.; PORTO, J.C.A. 1997. Efeito de fontes de nitrogênio e do tipo de silagem no desempenho de bovinos F1 Pardo-Suíço $x$ Nelore. In: REUNIÃO ANUAL DA SOCIEDADE BRASILEIRA DE ZOOTECNIA, 
34, 1997, Juiz de Fora. Anais... Juiz de Fora: Sociedade Brasileira de Zootecnia, p.283.

FERREIRA, R.N. 2005. Liberação de nitrogêno amoniacal no rumen com o uso de uréia encapsulada com polímero (Optigen 1200 Alltec). In: REUNIÃO ANUAL DA SOCIEDADE BRASILEIRA DE ZOOTECNIA, 42., 2005, Goiânia. Anais...Goiânia: SBZ.CD-ROM

FIRKINS, J.L.; YUAND, Z.; MORRISON, M., 2007. Ruminal nitrogen metabolism: perspectives for Integration of microbiology and nutrition for dairy. J. Dairy Sci., 90 (E. Suppl.): E1-E16.

FIRKINS, J. L.; ALLEN, M. S.; OLDICK B. S; ST-PIERRE, N. R. 1998. Modeling ruminal digestibility of carbohydrates and microbial protein flow to the duodenum. J. Dairy Sci. 81:3350-3369.

FORERO, O.; OWENS, F.N.; LUSBY, K.S. 2001.Evaluation of slow-release urea for winter supplementation of lacting range cows. Journal of Animal Science , v. 50, p. 532-538, 1980. GABARRA, P.R. Digestibilidade de nutrients e parâmetros ruminanis e sanguíneos de novilhos Nelore alimentados com fontes protéicas e energéticas com diferentes degradabilidades ruminais. 2001. 109p. Dissertação (Mestrado em Agronomia) - Escola Superior de Agricultura "Luiz de Queiroz". Universidade de São Paulo, Piracicaba, SP.

FROSLIE, A. 1997. Feed-related urea poisoning in ruminants. Folia Vet. Lat. 7: 1737.

GALINA, M.; ORSKOV, E.R.; PEREZ-GIL, F.; ORTIZ, R.M.A. 2003. Effect of slow intake urea supplementation on fattening of steers feed sugar cane tops (Saccharum officinarum) and (Zea mays) with or without SIUS. Ruminal fermentation, feed intake and digestibility. Livestok Production Science, v.83, p. $1-11$.

GALO, E., EMANUELE, S. M., SNIFFEN, C. J.; WHITE, J. H.; KNAPP, J. R., 2003. Effects of a polymer-coated urea product on nitrogen metabolism in lactating Holstein dairy cattle. J. Dairy Sci. 86: 2154-2162.

GOLOMBESKI, G.L.; KALSCHEUR, K.F.; HIPPEN A.R; SCHINGOETHE, D.J. 2006. Slow-release urea and highly fermentable sugars in diets fed to lactating dairy cows. J. Dairy Sci., 89: 4395-4403.

GUIDI, M.T. 1999. Efeito de teores e fontes de proteína sobre o desempenho de vacas de leite e digestibilidade dos nutrientes. 1999. Dissertação (Mestrado) - Escola Superior de Agricultura "Luiz de Queiroz", Universidade de São Paulo, Piracicaba.

HADDAD, C.M. 1984. Uréia em suplementos alimentares. In: SIMPÓSIO SOBRE NUTRIÇÃO DE BOVINOS - Uréia para ruminantes, 2., 1984, Piracicaba Anais... Piracicaba: FEALQ, p.119-141. 
HARMEYER, J.; MARTENS, H. 1980. Aspects of urea metabolism with reference to the goat. Journal of Dairy Science, v.63, p.1707-1728.

HARVATINE, K. J.; ALLEN, M. S. 2006. Effects of fatty acid supplements on milk yield and energy balance of lactating dairy cows. Journal of Dairy Science, v. 89 , p. $1081-1091$.

HENNESSY, D.W.; KOHUN, P.J.; WILLIAMSON, P.J. et al. 1995. The effect of nitrogen and protein supplementation on feed intake, growth and digestive function of steers with different Bos indicus, Bos taurus genotypes when fed a low quality grass hay. Australian Journal of Agriculture Research, v.46, p.1121-1136.

HENNING, P. H.; STEYN, D. G.; MEISSNER, H. H. 1991. The effect of energy and nitrogen supply pattern on rumen bacterial growth in vitro. Anim. Prod. 53:165-175.

HIGHSTREET, A.; ROBINSON, P.H.; ROBISON, J.; GARRETT, J.G., 2010. Response of Holstein cows to replacing urea with a slowly rumen released urea in a diet high in soluble crude protein. Livest. Sci., 129: 179-185.

HOOVER, W. H.; MILLER, T. K. 1992. Rumen digestive physiology and microbial ecology. Bull. 708T, Agric. Forestry Exp. Stn., West Virginia University, Morgantown.

HOOVER, W. H.; STOKES, S. R. 1991. Balancing carbohydrates and protein for optimum rumen microbial yield. J. Dairy Sci. 74:3630-3644.

HOOVER, W.H. 1986. Chemical factories involved in ruminal fiber digestion. J. Dairy Sci., 29(10):2755-1766.

HOOVER, W. H., KINCAID, C. R., VARGA, G. A.; THAYNE, W. V.; JUNKINS, L. L. 1982. Effects of solid and liquid flows on fermentation in continuous cultures. IV. pH and dilution rates. J. Anim. Sci. 58:692-699.

HUBER, J.T. 1994. Uréia ao nível do rúmen. In: SIMPÓSIO SOBRE NUTRIÇÃO DE BOVINOS, 2; Piracicaba, 1994. Anais. Piracicaba: FEALQ, P. $1-17$.

HUNTINGTON, G.B.; HARMON, D.L.; KRISTENSEN, N.B., HANSON, K.C.; SPEARS, J.W., 2006. Effects of a slowrelease urea source on absorption of ammonia and endogenous production of urea by cattle. Anim. Feed Sci. Tech., 130: 225-241.

HUNTINGTON, G.B.; ARCHIBEQUE, S.L. 1999. Practical aspects of urea and ammonia metabolism in ruminants. Proceedings of the American Society of Animal Science. 
HUSSEIN, H.S.; BERGER, L.L. 1995.Feedlot performance and carcass characteristics of Holstein steers as affected by source of dietary protein and level of ruminally protected lysine and methionine. Journal of Animal Science, v. 73, n. 12, p. 3503-3509.

INOSTROZA, J.F.; SHAVER, R.D.; CABRERA, V.E.; TRICÁRICO, J.M., 2010. Effect of diets containing a controlledrelease urea product on milk yield, milk composition, and milk component yields in commercial Wisconsin dairy herds and economic implications. Professional Animal Scientist, 26: 175-180.

JOUANY, J. P. 1996. Effects of rumen protozoa on nitrogen metabolism by ruminants. J. Nutr. 126:1335S-1346S.

KNAUS, W.F.; BEERMANN, D.H.; GUIROY, P.J. et al. 2001.Optimization of rate and efficiency of dietary nitrogen utilization through the use of animal byproducts and (or) urea and their effects on nutrient digestion in Holstein steers. Journal of Dairy Science, v.78, p.1060-1066.

KOZLOSKI, G.V. Bioquímica dos ruminantes. 2.ed. - Santa Maria: Ed. da UFSM, 2009. $216 \mathrm{p}$.

LUCCI, C.S. 1997. Nutrição e manejo de bovinos leiteiros. São Paulo: Manole,

LUCHIARI FILHO, A. 2000. Pecuária da carne bovina. 1르 ed. - São Paulo: A. Luchiari Filho. 134p.

MAGALHÃES, K.A. 2003. Níveis de uréia ou casca de algodão na alimentação da novilhos de origem leiteira em confinamento. Viçosa: Universidade Federal de Viçosa, 2003. 90p. Dissertação (Mestrado em Zootecnia) - Universidade Federal de Viçosa.

MAGALHÃES, K.A.; VALADARES FILHO, S.C.; VALADARES, R.F.D. 2002. Níveis de uréia em substituição ao farelo de soja na dieta de novilhos de origem leiteira em confinamento. 1. Desempenho. In: REUNIÃO ANUAL DA SOCIEDADE BRASILEIRA DE ZOOTECNIA, 39., 2002, Recife. Anais... Recife: Sociedade Brasileira de Zootecnia.

MALNIC, G.; MARCONDES, M. Fisiologia renal. 3.ed. São Paulo: EPU, 1986. 409p.

MANELLA, M.Q. 2004. Perfil de aminoácidos e estudo da cinética de degradação ruminal de alimentos em bovino Nelore recebendo diferentes 
proporções de concentrado. 2004. 104p. Tese (Doutorado). Escola Superior de Agricultura: "Luiz de Queiroz", Universidade de São Paulo, Piracicaba, SP.

MERTENS, D. R. 2002. Gravimetric determination of amylase-treated neutral detergent fibre in feeds with refluxing beakers or crucibles: collaborative study. Journal of AOAC International, v. 85, p. 1217-1240.

MERTENS, D.R. Regulation of forage intake. In: FAHEY Jr., G.C., (Ed.) Forage quality, evaluation and utilization. In: NATIONAL CONFERENCE ON FORAGE QUALITY, EVALUATION AND UTILIZATION. American Society of Agronomy. 1994. p.450-493.

MERTENS, D.A. 1992.Analysis of fiber in feeds and ist use in feed evaluation and ration formulation. In: Simpósio Internacional de Ruminantes, Lavras. Anais. Lavras: SBZ, 1992. p. 1-32.

MILTON, C. T.; BRANDT, R. T. Jr.; TITGEMEYER, E. C. 1997. Urea in dryrolled corn diets: finish steer performance, nutrient digestion, and microbial protein production. Journal of Animal Science, v.75, p.1415-1424.

MORAES, E.H.B.K. 2003. Suplementos múltiplos para recria e terminação de novilhos mestiços em pastejo durante os períodos de seca e transição secaáguas. Viçosa: Universidade Federal de Viçosa, 2003. 70p. Dissertação (Mestrado em Zootecnia) - Universidade Federal de Viçosa.

MORRIS,D.D; LARGE, S.M. 1993. Alterações no leucograma. In: Smith PB.Tratado de medicina interna de grandes animais. São Paulo, Manole,; 1: 437-446.

MOULD, F.L.; ORSKOV, E.R.; MANN, S.O. 1983. Associative effects of mixed feeds. 2. The effect of dietary additions of bicarbonate salts on the voluntary intake and digestibility of diets containing various proportions of hay and barley. Animal Feed Science and Tecnology, v.10, p. 15-25.

NATIONAL RESEARCH COUNCIL - NRC.. Nutrient requirements of dairy cattle. 7th ed. Washinton, D.C.: National Academic Press, 2001. p. 381.

NATIONAL RESEARCH COUNCIL - NRC. 1996. Nutrient requirements of beef cattle. 7.ed. Washington, D.C.: National Academy. 242p.

NOCEK, J. E. In situ and other methods to estimate ruminal protein and energy digestibility. A review. Journal of Dairy Science, v. 71, p. 2051-2069, 1988. 
OBEID, J.A., GOMIDE, J.A., SILVA, J.F.C. 1980. Efeito de níveis de uréia e do manejo da alimentação sobre o consumo alimentar e o ganho de peso de novilhos Zebu em confinamento. Revista Sociedade Brasileira de Zootecnia. 9 (3) : $484-493$.

OLIVEIRA JR, R.C.; PIRES, A.V.; FERNANDES, J.J.R; SUSIN, I.; SANTOS, F.A.P.; ARAÚJO, R.C.A. 2004. Substituição Total do Farelo de Soja por Uréia ou Amiréia, em Dietas com Alto Teor de Concentrado, sobre a Amônia Ruminal, os Parâmetros Sangüíneos e o Metabolismo do Nitrogênio em Bovinos de Corte. R. Bras. Zootec., v.33, n.3, p.738-748.

OLIVEIRA Jr., R.C. 2002. Substituição do farelo de soja por uréia e amiréia em dietas de bovinos de corte. I. digestibilidade dos nutrientes, balanço de nitrogênio, parâmetros ruminais e sanguíneos; II. desempenho e III. Avaliação de indicadores de digestibilidade. 2002. 196 p. Tese (Doutorado). Escola Superior de Agricultura: "Luiz de Queiroz", Universidade de São Paulo, Piracicaba, SP.

OLTJEN, R. R.; SLYTER L. L.; WILLIAMS, E. E.; KERN, D. L. 1971. Influence of the branched-chain volatile fatty acids and phenylacetate on ruminal microorganisms and nitrogen utilization by steers fed urea and isolated soyprotein. J. Nutr. 101:101-112.

ORELLANA BOERO, P.; BALCELLS, J.; MARTÍN-ORÚE, S. M. 2001. Excretion of purine derivates in cows: endogenous contribution and recovery of exogenous purine bases. Livestock Production Science, v. 68, p. 243-250.

ORSKOV, E.R.; MACLEOD, N.A. 1982. The determination of the minimal nitrogen excretion in steers and dairy cows and physiological and practical implications. British Journal of Nutrition, v.47, p.625-636.

ORTOLANI, E.L.; ANTONELLI, A.C. Acute ammonia poisoning in cattle - a review. Curr top toxicol. 2004; 1: 19-32.

ORTOLANI, E.L, ANTONELLI, A.C. 2000 Ammonia toxicity from urea in a Brazilian dairy goat flock. Vet. Hum. Toxicol., 42: 87-9.

OWENS, F.N.; ZINN, R. Protein metabolism of ruminant animal. In: $\mathrm{CHURCH,}$ D.C. (Ed.) The ruminant animal: digestive physiology and nutrition. Englewood Cliffs: Simon \& Schuster, 1988. p.227-249.

PAIXÃO, M.P.; VALADARES FILHO, S.C.; LEÃO, M.I. 2006. Uréia em dietas para bovinos: consumo, digestibilidade aparente, ganho de peso, característica da carcaça e produção microbiana. Revista Brasileira de Zootecnia, v.35, n.6, p.2451-2460.

PAIXÃO, M. L. 2004. Uréia em dietas para bovinos: desempenho, consumo, digestibilidade, parâmetros ruminais e variação diária na excreção de 
indicadores. Viçosa: Universidade Federal de Viçosa, 2004. 85p. Dissertação (Mestrado em Zootecnia) - Universidade Federal de Viçosa..

PINOS-RODRÍGUEZ, J.M.; PEÑA, L.Y., GONZÁLEZ-MUÑOZ, S.S., BÁRCENA, R.; SALEM, A. 2010. Effects of a slow-release coated urea product on growth performance and ruminal fermentation in beef steers. Italian J. Anim. Sci., DOI:10.4081/ijas.2010.e4.

PIRES, A.V.; OLIVEIRA JR,R.C.; FERNANDES, J.J.R.; SUSIN, I.; SANTOS, F.A.P.; ARAÚJO, R.C.; GOULART, R.C.D. 2004. Substituição do farelo de soja por uréia ou amiréia na dieta de bovinos de corte confinados. Pesq. agropec. bras., Brasília, v.39, n.9, p.937-942.

PRESTON, R.L.; SCHNAKENBERG, D.D.; PFANDER, W.H. Protein utilization in ruminants. I. 1965. Blood urea nitrogen as affected by protein intake. Journal of Nutrition, v.86, p.281-288.

PROKOP, M.J.; KLOPFENSTEIN, T.J. 1977. Slow ammonia release urea. Nebraska Beef Cattle Report No. EC 77-218 Nebraska.

PUGA, D.C.; GALINA H.M; PEREZ-GIL, R.F.; G.L., 2001. Effect of a controlledrelease urea supplement on rumen fermentation in sheep fed a diet of sugar cane tops Saccharum officinarum), corn stubble (Zea mays) and King grass (Pennisetum purpureum). Small Rumin. Res., 39: 269-276.

RENNÓ, L.N., VALADARES FILHO, S.C.; PAULINO, M.F.; LEÃO, M.I.; VALADARES, R.F.D.; RENNÓ, F.P.; PAIXÃO, M.L. 2008. Níveis de uréia na ração de novilhos de quatro grupos genéticos: parâmetros ruminais, uréia plasmática e excreções de uréia e creatinina. R. Bras. Zootec., v.37, n.3, p.556562.

RENNÓ, L.N.; FILHO, S.C.V.; VALADARES, R.F.D.; CECON5, ALFREDO BACKES, P.R.A.; RENNÓ, F.P; ALVES, D.D.A.; SILVA, P.A. 2005. Níveis de Uréia na Ração de Novilhos de Quatro Grupos Genéticos: Consumo e Digestibilidades Totais. R. Bras. Zootec., v.34, n.5, p.1775-1785.

RENNÓ, L. N. 2003. Consumo, digestibilidade total e parcial, produção microbiana, parâmetros ruminais e excreções de uréia e creatinina em novilhos alimentados com dietas contendo quatro níveis de uréia ou dois de proteína. 2003.252 p. Tese (Doutorado em Zootecnia) - Universidade Federal de Viçosa, Viçosa.

ROLLER, W.W.; HALE,W.H.; CHENG, E.W.; BURROUHS,W. 1955. The influence of oral administration of non-protein nitrogen compounds upon blood and urea levels in lambs. Journal of Animal Science, Champaign, v. 14, n.1, p. 118-131. 
RUSSELL, J.B.; MUCK, R. E.; WEIMER, P. J., 2009. Quantitative analysis of cellulose degradationand growth of cellulolytic bacteria in therumen. FEMS Microbiol. Ecol., 67: 183-197.

RUSSELL, J. B., SNIFFEN, C. J.; VAN SOEST, P. J. 1983. Effect of carbohydrate limitation on degradation and utilization of casein by mixed rumen bacteria. J. Dairy Sci. 66:763-775.

RUSSEL,J.B., O'CONNOR,J.D., FOX,D.G., SNIFFEN,C.J., VAN SOEST,P.J. A. 1992. Net Carbohydrate and Protein System for evaluating cattle diets. I. Ruminal fermentation. J. Anim. Sci., 70: 3551-3561.

SALES, M.F.L., PAULINO, M.F.P.; FILHO, S.C.V.; PORTO, M.O.; MORAES, E.H.B.K; BARROS, L.V. 2008. Níveis de uréia em suplementos múltiplos para terminação de novilhos em pastagem de capim-braquiária durante o período de transição águas-seca. R. Bras. Zootec., v.37, n.9, p.1704-1712.

SALMAN, A.K.D.; MATARAZZO, S.V., EZEQUIEL, J.M.B. 1996. Estudo do Balanço nitrogenado e da digestibilidade da matéria seca e da proteína de rações para ovinos suplementados com amiréia, uréia ou farelo de algodão. In: REUNIÂO ANUAL DA SOCIEDADE BRASILEIRA DE ZOOTECNIA, 33., 1996, Fortaleza. Anais... Fortaleza: SBZ, p. 197- 199.

SANTOS, F.A.P. Metabolismo das proteínas. In: BERCHIELLI, T.T.; PIREZ, A.V.; OLIVEIRA, S.G. 2006. Nutrição de ruminantes. Jaboticabal: FUNEP, 583p.

SANTOS, G.T.; CAVALIERI, F.L.B.; MODESTO, E.C. 2001. Recentes avanços em nitrogênio não protéico na nutrição de vacas leiteiras. In: Anais do 220 Simpósio Internacional em Bovinocultura de Leite: novos conceitos em nutrição; 2001b, Lavras. Lavras: UFLA; p.199-228.

SANTOS, F.A.P.; HUBER, J.T., THEURER, C.B.; SWINGLE, R.S.; SIMAS, J.M., CHEN, K.H. 1998. Milk yield and composition of lactating cows fed steamflaked sorghum and graded concentrations of ruminally degradable protein. J. Dairy Sci.; 81: 215-20.

SATTER, L.D. \& ROFFLER, R.E. 1975. Nitrogen Requirement and utilization in dairy cattle. Journal of Dairy Science, v. 58, p. 1219.

SHAIN, D. H.; STOCK, R. A.; KLOPFENSTEIN, T.J. 1998. Effect of degradable intake protein level on finishing cattle performance and ruminal metabolism. Journal of Animal Science, v.76, p. 242-248. 
SHIEHZADEH, S.A.; HARBERS, L.H. 1974. Soybean meal, urea and extruded starch-urea products compared as protein supplements in high-roughage lamb rations. Journal of Animal Science, v.38, p.206-212.

SILVA, D. J.; QUEIROZ, A. C. 2002. Análise de Alimentos (Métodos químicos e biológicos). Viçosa: Impr. Univ., p. 235.

SILVA, F.F.2001. Desempenho, caraterísticas de carcaça, composição corporal e exigências nutricionais (de energia, proteína, aminoácidos e macrominerais) de novilhos Nelore, nas fases de recria e engorda, recebendo diferentes níveis de concentrado e proteína. Viçosa: UFV, 2001. 211p. Tese (Doutorado em Zootecnia) - Universidade Federal de Viçosa.

SILVEIRA, R.N.; BERCHIELLI, T.T.; CANESIN, R.C.; MESSANA, J.D.; FERNANDES, J.J.R.; PIRES, A.V. 2009. Influência do nitrogênio degradável no rúmen sobre a degradabilidade in situ, os parâmetros ruminais e a eficiência de síntese microbiana em novilhos alimentados com cana-de-açúcar. R. Bras. Zootec., v.38, n.3, p.570-579.

SMITH, R.H. 1975. Nitrogen metabolism in the rumen and composition and nutritive value of nitrogen compounds entering the duodenun. In: McDONALD, I.W. E WARNER, A.C.I. Ed. Digestion and metabolism in the ruminant, pg. 399415. University of New England, Australia.

SNIFFEN, C.J., BEVERLY, R.W., MOONEY, C.S. 1993. Nutrient requirements versus supply in the dairy cow: strategies to account for variability. J. Dairy Sci., 76(10):3160-3178.

SOUZA, V.G.; PEREIRA, O.G.; VALADARES FILHO, S.C. 2002. Consumo e desempenho de bovinos de corte recebendo dietas com diferentes níveis de uréia. In: REUNIÃO ANUAL DA SOCIEDADE BRASILEIRA DE ZOOTECNIA, 39, Recife. Anais... Recife: SBZ.

STERN, M. D.; VARGA, G. A.; CLARK, J. H.; FIRKINS, J. L.; HUBER, J. T.; PALMQUIST, D. L. 1994. Evaluation of chemical and physical properties of feeds that affect protein metabolism in the rumen. J. Dairy Sci. 77:2762-2786.

STERN, M. D.; HOOVER, H.; SNIFFEN, C. J.; CROOKER, B. A.; KNOWLTON, P. H. 1978. Effects of nonstructural carbohydrate, urea and soluble protein on microbial protein synthesis in continuous culture of rumen contents. J. Anim. Sci. 47:944 956. 
ST-PIERRE, N. R. 2001. Invited review: Integrating quantitative findings from multiple studies using mixed model methodology. J. Dairy Sci. 84:741-755.

TAMMINGA, S. 1996. Areview on environmental impacts of nutritional strategies in ruminants. J. Anim. Sci. 74:3112-3124.

TAYLOR-EDWARDS, C.C., ELAM, N.A., KITTS, S.E., MCLEOD, K.R., AXE, D.E., VANZANT, E.S., KRISTENSEN, N.B.; HARMON, D.L. 2009. Influence of slow-release urea on nitrogen balance and portal-drained visceral nutrient flux in beef steers. J. Anim. Sci., 87: 209-221.

THOMAS, E.E.; MASON, C.R.; SCHMIDT, S.P. 1984. Relation of performance and certain physiological responses to the metabolizable protein and urea content of cattle diets. Journal of Animal Science, v. 58, n.5, p. 1285 - 1291, 1984.

URANO, F.S.; PIRES, A.V.; SUSIN, I. et al. 2006. Desempenho e características da carcaça de cordeiros confinados alimentados com grãos de soja. Pesquisa Agropecuária Brasileira, v.41, n.10, p.1525-1530.

VALADARES FILHO S. 2002. Exigências nutricionais de gado de leite. In: Anais do Simpósio Mineiro de Nutrição de Gado de Leite; 2002, Belo Horizonte. Belo Horizonte: Escola de Veterinária, UFMG.

VALADARES, R. F. D.; BRODERICK, G. A.; VALADARES FILHO, S. C. 1999. Effect of replacing alfafa with high moisture corn on ruminal protein synthesis estimated from excretion of total purine derivatives. Journal of Dairy Science, v. 82 , p. 2686-2696.

VAN SOEST, P.J. 1994. Nutritional ecology of the ruminant. 2. ed. London: Constock Publishing Associates, USA, 476p.

VAN SOEST, P. J.; MASON, V. C. 1991. The influence of Maillard reaction upon the nutritive value of fibrous feeds. Animal Feed Science and Technology, v. 32 , n. 1 , p. $45-53$.

VELLOSO, L. 1984. Uréia em rações de engorda de bovinos. In: SIMPÓSIO SOBRE NUTRIÇÃO DE BOVINOS - Uréia para ruminantes, 2., 1984, Piracicaba. Anais... Piracicaba: FEALQ, p.174-199. 
VISEK, W.J. 1984. Amonia: Its effects on biological systems. Metabolic hormones, and reproduction. J. Dairy Sci., 67(3): 481-498.

WEISS, W. P.; CONRAD, H. R.; PIERRE, N. R. S. T. 1992. A theoreticallybased model for predicting total digestible nutrient values of forages and concentrates. Animal Feed Science Technology, v. 39, p. 95-110.

WILSON, G.; MARTZ, F.A.; CAMPBELL, J.R. et al. 1975. Evaluation of factors responsible for reduced voluntary intake of urea diets for ruminants. Journal of Animal Science, v.41, n.5, p.1431-1437.

XIN, H.S.; SCHAEFER, D.M.; LIU, Q.P.; AXE, D.E. MENG, Q.X. 2010. Effects of polyurethane coated urea supplement on in vitro ruminal fermentation, ammonia release dynamics and lactating performance of Holstein dairy cows fed a steam-flaked corn-based diet. Asian-Aust. J. Anim. Sci., 23: 491-500. 